\title{
The Financial Reform Act: Will It Succeed in Reversing the Causes of the Subprime Crisis and Prevent Future Crises?
}

Charles W. Murdock

Loyola University Chicago, cmurdoc@luc.edu

Follow this and additional works at: https://ecommons.luc.edu/social_justice

Part of the Law Commons

\section{Recommended Citation}

Murdock, Charles W., "The Financial Reform Act: Will It Succeed in Reversing the Causes of the Subprime Crisis and Prevent Future Crises?" (2014). Social Justice. 40.

https://ecommons.luc.edu/social_justice/40

This is brought to you for free and open access by the Centers at Loyola eCommons. It has been accepted for inclusion in Social Justice by an authorized administrator of Loyola eCommons. For more information, please contactecommons@luc.edu. 
Summary: The Financial Reform Act: Will It Succeed in Reversing the Causes of the Subprime Crisis and Prevent Future Crises? By: Professor Charles W. Murdock

The current financial crisis, which could have plunged the world into a financial abyss similar to the Great Depression, is far from resolved. The financial institutions, which this article asserts caused the crisis, have returned to profitability and have paid billions of dollars in bonuses, while ordinary Americans have borne the brunt of the meltdown, with formal unemployment hanging around the $10 \%$ mark. This has caused some to comment that profits have been privatized and risk has been socialized. Two years after the economic meltdown, the impact continues as local governments turn off streetlights, cut back on police and fire departments, close down transit systems, return paved roads to gravel, and put schools on a four-day week.

Democrats in the House and Senate finally agreed on a financial regulation bill. Opposition to the bill in part was based on the belief that Fannie Mae and Freddie Mac were the cause of the subprime crisis. However, as this article demonstrates, it was the "big banks," by funding the subprime lenders, buying their mortgages and securitizing them, slicing them to form CDOs and synthetic CDOs through derivatives, and leaning on the credit rating agencies to get AAA ratings for junk, there were the primary cause of the financial crisis.

In other words, we need more light and less heat on an issue this grave.

Parts I and II are fairly dry: they deal with data. But, in a financial crisis, numbers are important. Part I deals with the incredible increase in assets under investment, which created the demand for the toxic mortgages, while Part II analyzes the changing characteristics of the subprime mortgages and their dramatic increase in volume and riskiness, a fact that was not recognized by the financial professionals.

In Part III, the roles of the borrowers, the mortgage brokers, the mortgage lenders, Fannie Mae and the investment banks, the credit rating agencies, and derivatives are explored, together with the incentives that drove each participant. The various titles of the Financial Reform Act are analyzed from the standpoint of the impact they will have on the foregoing players in order to prevent future crises.

The Conclusion asserts that the Financial Reform Act should prevent a future financial crisis that mirrors the past crisis. However, it does not adequately deal with the underlying issue that drives any financial crisis: management incentives that lead to excessive risk-taking. Nor does it deal with the ever increasing aggregation of financial power in large financial institutions. 
Professor Charles W. Murdock

Loyola University Chicago School of Law

The Financial Reform Act: Will It Succeed in Reversing the Causes of the Subprime Crisis and Prevent Future Crises?

Table of Contents

Page

I. The Extraordinary Increase in Assets under Investment ................................................................

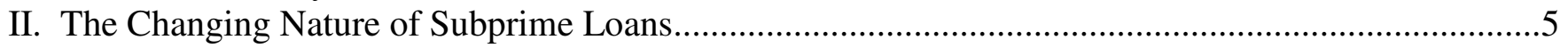

III. Who Was Responsible for These Risky Loans and What Drove Their Actions...................................8

A. Fatal Flaws in the Origination of Toxic Mortgages ..................................................................8

1. The borrower: opportunist or victim? .........................................................................

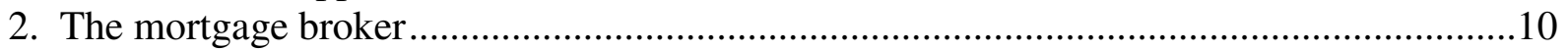

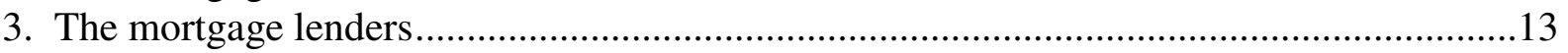

4. The Response of the Financial Reform Act to the Creation of Toxic Mortgages ................17

B. The Securitization Players: Investment Bankers and Credit Rating Agencies ..........................21

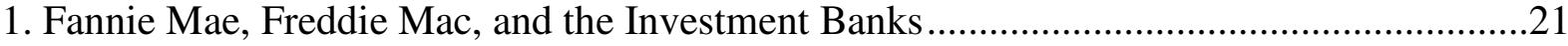

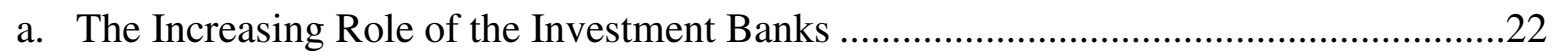

b. The Risky Nature of Loans Securitized by Investment Banks ...................................23

c. Investment Bank Financing of Subprime Lenders ........................................................24

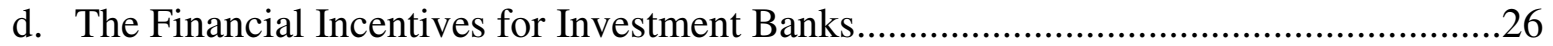

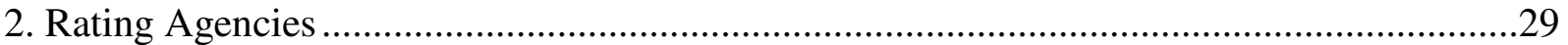

3. The Tepid Response of the Financial Reform Bill to the Investment Banks.........................33

a. "No Skin in the Game" Versus Risk Retention ............................................................33

b. The "Tired" Solution to Executive Risk Taking................................................................35

c. Inadequate Capitalization.............................................................................................

d. Proprietary Trading and the Volcker rule ...................................................................42

e. Too Big to Fail and Stemming Systemic Risk …………………………………….....44

4. The Financial Reform Act's Aggressive Approach toward the Credit Rating Agencies .....50

a. The Credit Rating Agencies, the First Amendment, and Civil Liability .........................51

b. Structural and Transparency Changes ........................................................................53

C. Derivatives: AIG, Goldman Sachs, and Credit Default Swaps ..............................................56

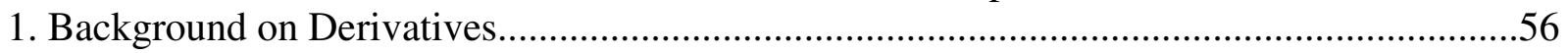

2. AIG's Entry into the Derivative Business and Downfall.....................................................58

3. Credit Default Swaps, Goldman Sachs, and Magnetar.......................................................61

4. The Response of the Financial Reform Act to Derivatives ...................................................64

V. Conclusion 


\section{The Financial Reform Act: Will It Succeed in Reversing The Causes of the Subprime Crisis and Prevent Future Crises?}

The current financial crisis, which could have plunged the world into a financial abyss similar to the Great Depression, ${ }^{1}$ is far from resolved. The financial institutions, which this article asserts caused the crisis, have returned to profitability and have paid billions of dollars in bonuses, ${ }^{2}$ while ordinary Americans have borne the brunt of the meltdown, with formal unemployment hanging around the $10 \%$ mark. ${ }^{3}$ This has caused some to comment that profits have been privatized and risk has been socialized. Two years after the economic meltdown, the impact continues as local governments turn off streetlights,

\footnotetext{
* Professor of Law, Loyola University Chicago. I would like to thank Professor Elizabeth Warren, Harvard University and Chair of the Congressional Oversight Panel, and Representative Bill Foster, member, House Financial Services Committee, for their comments.

${ }^{1}$ On September 18. 2008, Secretary Paulson met with members of Congress; Senator Dodd reported that Paulson told them: "Unless you act, the financial system of this country and the world will melt down in a matter of days." Senator Dodd added: "There was literally a pause in that room where the oxygen left." Frontline, (PBS television broadcast Feb. 17 2009), available at http://www.pbs.org/wgbh/pages/frontline/meltdown/etc/script.html. More recently, Prof. Blinder of Princeton, and a former vice chairman of the Federal Reserve Board, and Mark Zandi, the chief economist Of Moody's Analytics, and the adviser to Sen. McCain in his presidential campaign, reported that, had there not been governmental intervention, over 16 million jobs would have been lost, as opposed to the 8 million the country has experienced, which would have led to a second Great Depression. See Sewell Chan, In the Study, 2 Economists Say Intervention Helped Avert a Second Depression, , N.Y. TIMES, July 28, 2010, available at http://www.nytimes.com/2010/07/28/business/economy/28bailout.html.

${ }^{2}$ Eric Dash, Federal Report Faults Banks on Huge Bonuses, N.Y. TIMES July 23, 2010, available at http://www.nytimes.com/2010/07/23/business/23pay.html? r=1\&th\&emc=th. (The special master called $80 \%$ of pay unmerited. He looked at 600 executives at 17 banks received $\$ 2.03$ billion in payouts.)

${ }^{3}$ The situation for ordinary Americans was summarized by Bob Herbert of the New York Times as follows:
}

What's needed is the same sense of urgency about helping struggling families and putting people back to work as the Bush and Obama crowds showed when the banks were about to go bust. That sense of urgency is always missing when it's ordinary people who are in trouble.

Millions of Americans are stuck in an economic depression. Several million have either lost their homes to foreclosure during the recession or are in imminent danger of losing them. The long-term unemployed are facing painful daily choices on such basic matters as whether to buy food or refill needed prescription medication or pay electric bills to keep the lights on.

Back in February, The Times's Peter Goodman wrote about the new poor, "people long accustomed to the comforts of middle-class life who are now relying on public assistance for the first time in their lives - potentially for years to come."

There can be no real national recovery with so many millions of people in such deep economic distress.

Bob Herbert, Outside the Casino, N. Y. TIMES, JULY 13, 2010, available at http://www.nytimes.com/2010/07/13/opinion/13herbert.html?_r=1\&th=\&emc=th\&pagewanted=print. 
cut back on police and fire departments, close down transit systems, return paved roads to gravel, and put schools on a four-day week. ${ }^{4}$

Democrats in the House and Senate finally agreed on a financial regulation bill, which Republicans almost uniformly opposed. In a sense, the ideological dispute is between consumer protection versus "big bank" protection. The rationale for Republican opposition seems to be that the current bill does not deal with Fannie Mae and Freddie Mac; according to the Republicans, these entities, and the Community Reinvestment Act, were the cause of the subprime crisis. ${ }^{5}$ However, as this article demonstrates, it was the "big banks," by funding the subprime lenders, buying their mortgages and securitizing them, slicing them to form CDOs and synthetic CDOs through derivatives, and leaning on the credit rating agencies to get AAA ratings for junk, there were the primary cause of the financial crisis.

\footnotetext{
${ }^{4}$ Michael Cooper, Governments Go to Extremes As the Downturn Wears On, N.Y. TiMES, Aug. 7, 2010, available at http://www.nytimes.com/2010/08/07/us/07cutbacksWEB.html?_r=1\&th\&emc=th; Paul Krugman, America Goes Dark, N.Y. TIMES, AUG. 8, 2010, available at http://www.nytimes.com/2010/08/09/opinion/09krugman.html.

${ }^{5}$ Rep. John Boehner Press Release, July 22, 2010 “Left untouched: Fannie Mae and Freddie Mac, the government mortgage companies that sparked the meltdown by giving high-risk loans to people who couldn't afford it." Available at http://johnboehner.house.gov/News/DocumentSingle.aspx?DocumentID=199958.
}

Similarly, the American Enterprise Institute, a conservative think tank, also laid the blame for the subprime crisis solely on the shoulders of Fannie Mae and Freddie Mac:

This Outlook tells the disheartening story of how the GSEs [Fannie Mae and Freddie Mac] sold out the taxpayers by taking huge risks on substandard mortgages, primarily to retain congressional support for the weak regulation and special benefits that fueled their high profits and profligate executive compensation. As if that were not enough, in the process, the GSEs' operations promoted a risky subprime mortgage binge in the United States that has caused a worldwide financial crisis.

Peter J. Wallison \& Charles W. Calomiris, The Last Trillion-Dollar Commitment: The Destruction of Fannie Mae and Freddie Mac, America Enterprise Institute, Sep. 30, 2008, at 1, available at http://www.aei.org/publications/pubID.28704/pub_detail.asp.

With respect to the Community Reinvestment Act, Neil Cavuto of Fox News has opined that, if banks hadn't been forced to make loans to "minorities and risky folks," the crisis would not have occurred. See Media Matters, Cavuto suggests Congress should have warned that "[l]oaning to minorities and risky folks is a disaster," Sept. 19, 2008, available at http://mediamatters.org/mmtv/200809190021; see also Clarence Page: Lame rap aimed at poor folks, CHGO. TRIB., Oct. 8, 2008, available at http://archives.chicagotribune.com/2008/oct/08/news/chi-oped1008pageoct08. Another conservative pundit, Ann Coulter, blamed the subprime crisis on "affirmative action lending policies." See Ann Coulter, They Gave Your Mortgage to a Less Qualified Minority, Sept. 24, 2008, available at http://www.anncoulter.com/cgilocal/printer_friendly.cgi?article=275. Representative Michele Bachmann accused the CRA and President Bill Clinton of forcing banks to give out loans "on the basis of race and often little else." Available at http://minnesotaindependent.com/10758/bachmann-blaming-minority-lending-for-economic-crisis-does-not-mean-im-aracist. But see C-Span, Predatory Mortgages and Foreclosures (testimony of Marc H. Morial, CEO Nat'l Urban League, Oct. 16, 2008, and letter, Chrm. Ben Bernanke to Sen. Robert Menendez, Nov. 25, 2008), available at http://www.cspanvideo.org/congress/?q=node/77531\&id=8963151. 
A day after the Financial Reform Bill ${ }^{6}$ was signed into law by Pres. Obama, the minority leader of the House, Congressman John Boehner, said at his weekly press briefing that "the financial regulatory bill that the president signed this week is just another big-government power grab that will make it even harder to create jobs. It provides for permanent bailouts to President Obama's Wall Street allies at the expense of small businesses and community banks across our country. Frankly, it's just more of the same."7 Since the bill was a response to the worst financial crisis since the Great Depression and is aimed at preventing another such financial meltdown, it is critical to understand what were the real causes of the current financial crisis and the extent to which the Financial Reform Act will remediate the past and provide assurance that the future will not lead to a repeat of history. In other words, we need more light and less heat on an issue this grave.

Parts I and II are fairly dry: they deal with data. But, in a financial crisis, numbers are important. Part I deals with the incredible increase in assets under investment, which created the demand for the toxic mortgages, while Part II analyzes the changing characteristics of the subprime mortgages and their dramatic increase in volume and riskiness, a fact that was not recognized by the financial professionals.

In Part III, the roles of the borrowers, the mortgage brokers, the mortgage lenders, Fannie Mae and the investment banks, the credit rating agencies, and derivatives are explored, together with the incentives that drove each participant. The various titles of the Financial Reform Act are analyzed from the standpoint of the impact they will have on the foregoing players in order to prevent future crises. The Financial Reform Act should markedly change lending practices. It should also put a stop to the shameful role of the credit rating agencies that went from trusted analysts to wholesaling AAA ratings. However, the impact on the big banks remains to be seen. With respect to "too big to fail," the Act fails to address adequately the "too big" issue, but does create a sound mechanism to deal with systemically large institutions that may fail in the future.

The Conclusion asserts that the Financial Reform Act should prevent a financial crisis in the future that mirrors the past crisis. However, it does not specifically deal with the underlying issue that drives any financial crisis: management incentives that lead to excessive risk-taking. Nor does it deal with the ever increasing aggregation of financial power in large financial institutions.

\section{The Extraordinary Increase in Assets under Investment}

As alluded to above, one of the drivers of the subprime crisis was the surge in wealth experienced in many countries around the world. Between 2002 and 2007 there was a tremendous upsurge in the amount of assets available for investment that were seeking a profitable, yet safe, return. While assets under investment over the decades had grown to $\$ 37$ trillion by 2002 , these assets basically doubled between 2002 and 2007 to $\$ 73$ trillion. ${ }^{8}$ The United States has historically been attractive to

\footnotetext{
${ }^{6}$ On July 21, 2010, the Dodd-Frank Wall Street Reform and Consumer Protection Act, H.R.4173, $111^{\text {th }}$ Congress (ENR 2010), P.L. 111-203, hereinafter sometimes referred to as the "Financial Reform Act," or simply the "Act," and cited as H.R.

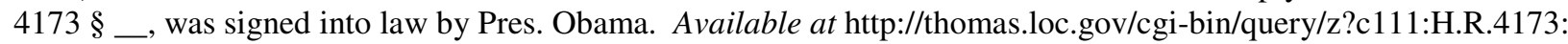

${ }^{7}$ Boehner Press Release, supra note 3.

${ }^{8}$ See InTERNATIONAL FinANCIAL SERVICES LONDON OCTOBER 2008, Fund MANAGEMENT REPORT 7 (April 2008), available at http://www.ifsl.org.uk/upload/CBS_Sovereign_Wealth_Funds_2008.pdf (last visited Oct. 6, 2009).
} 
both domestic and foreign investment. But treasury bonds, from 2003 to 2005, ranged from a little over $1 \%$ to a little over $4 \%$, depending upon the date and maturity. ${ }^{9}$ Investors, seeking a better but yet safe return, turned to real estate securities which, historically, had a relatively low default rate. ${ }^{10}$

When there is a surge of demand, the demand curve shifts upward to the right, normally resulting in higher prices. What is not always understood is that risk is a part of the price and what occurred in the subprime markets as a result of the surge in demand was that the product purchased became much riskier. Mortgage originations grew modestly from 1990 until 2001; they then exploded, particularly with respect to refinancings. See graph below. ${ }^{11}$

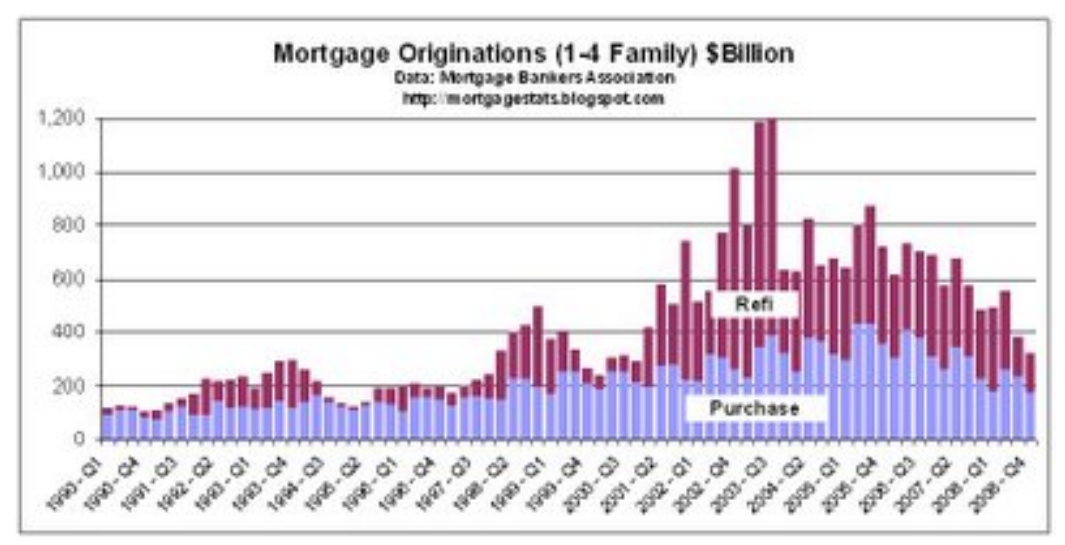

Home mortgage debt approximately doubled between 1990 and 2001; however, in the next five years between 2001 and 2006, it basically doubled again. ${ }^{12}$ In a sense, the pool of borrowers constituting a sound risk was depleted and was replaced by a pool of less creditworthy risks, whether by virtue of their personal financial characteristics or the inflated value of the real estate underlying the security that they were offering.

\section{The Changing Nature of Subprime Loans}

The causes of the subprime crisis, and the responsibility therefore, cannot be understood without a perspective on the nature of subprime loans, their explosive growth, and how the risk characteristics of these loans grew riskier over time. It is important to identify the period during which this move towards greater risk took place in order to assess who were the prime contributors to the crisis and what motivated them. Hopefully, the following two pages of data analysis will not discourage the reader,

\footnotetext{
${ }^{9}$ See Statistical Abstract of the United States 2009, Bond Yields: 1980 to 2007, tbl 1158, http://www.census.gov/compendia/statab/tables/09s1158.xls (last visited Oct. 6, 2009).

${ }^{10}$ For example, total loans in the foreclosure process from 1990 to 2007, before the real estate bubble burst, ranged from $0.9 \%$ to $1.5 \%$. See Census Bureau tbl 1154, http://www.census.gov/compendia/statab/tables/09s1154.xls (last visited Oct. 6, 2009).

1119 Years of Mortgage Origination Data 1990-2008, Mortgage Statistics (Feb. 13, 2009), http://mortgagestats.blogspot.com/2009/02/19-years-of-mortgage-origination-data.html.

12 In 1990 mortgage debt was \$2.621 trillion; in 2001, \$5.678 trillion; and in $2006 \$ 10.444$ trillion. See Board of Governors of the Federal Reserve System, Federal Reserve Statistical Release, Z.1, Flow of Funds Accounts of the United States, Mar. 6, 2008, http://www.federalreserve.gov/releases/z1/20080306/.
} 
since an understanding of this data is necessary to allocate the appropriate responsibility between the investment banks and the government sponsored entities, such as Fannie Mae and Freddie Mac, and to understand how management of the commercial and investment banks, and the non-bank lenders, were indifferent to the risk that they were undertaking.

From 2000 to 2003, fixed rate subprime mortgages constituted about $33 \%$ of subprime mortgages, with the percentage being basically constant across time. ${ }^{13}$ On the other hand, adjustable rate mortgages which would reset to a higher interest rate after two or three years, averaged about $60 \%$. These mortgages are sometimes described as 2/28 or 3/27 mortgages, reflecting the fact that a low teaser rate would be in effect for two or three years, and then the mortgage would reset to a much higher interest rate, often leading to defaults. ${ }^{14}$

However, from 2004 to 2006, the fixed rate subprime percentage dropped to about $25 \%$. In contrast, the adjustable rate mortgages increased to over $70 \%$ in 2004-2006. While the percentage change moved only modestly toward riskier investments, from a volume perspective, the dollar volume of subprime mortgages increased from $\$ 100$ billion in 2000 to $\$ 600$ billion in 2006 , a $600 \%$ increase. $^{15}$

What is the significance of the foregoing data? It illustrates that not only was there an explosive growth in a risky class of loans, namely subprime loans, but also that the composition of these loans was growing riskier over time, as the percentage of adjustable rate loans in the subprime class also increased.

There is a similar, and even more distressing, picture with respect to alt-A-loans. Alt-A loans are typically low documentation loans that were originally designed for credit-worthy, self-employed persons who could not meet the documentation requirements for traditional loan underwriting. For example, such person would not have a W-2 form from their employer to evidence their income. As discussed in the next section, these loans evolved into what became known as "liars' loans."

The dollar volume of Alt-A loans was only $\$ 25$ billion in 2000 but increased to $\$ 400$ billion in $2006,{ }^{16}$ an increase of $1,600 \%$. Sparking this rise was a loosening of underwriting standards. From 2000 to 2003 , the percentage of fixed rate Alt-A loans slowly dropped from $85 \%$ to $71 \%$. However, from 2004 to 2006, the percentage of fixed rate loans dropped markedly and was steady at about $38 \%$.

\footnotetext{
${ }^{13}$ Government Accountability Office, Characteristics and Performance of Nonprime Mortgages, July 28, 2009, http://www.gao.gov/new.items/d09848r.pdf ("GAO Report"). The data in this section on the percentages of subprime and Alt-A loans is derived from Tables 2 and 3 in Enclosure I, pages 24-25.

${ }^{14}$ A Federal Reserve Bank study found that about $70 \%$ of subprime loans were what is known as " $2 / 28$ " or " $3 / 27$ " loans, meaning that that they have a low teaser rate for two or three years, and then reset to a much higher interest rate which can double the mortgage payment. See Kelly D. Edmiston \& Roger Zalneraitis, Rising Foreclosures in the United States: A Perfect Storm, FED. RES. BANK OF KAN. CITY ECON. REV., Fourth Quarter 2007, at 127-128, available at http://www.kc.frb.org/publicat/econrev/PDF/4Q07Edmiston.pdf.

${ }^{15}$ GAO Report, supra note 13, at 1.

${ }^{16} I d$.
} 
What products replaced the fixed rate Alt-A? One essentially new product was what the GAO described as payment-option ARMs, ${ }^{17}$ but which have been more colorfully described as "pic-a-pay" loans. ${ }^{18}$ These loans comprised only about $2 \%$ of Alt-A loans in 2000-2003 but, during 2004 to 2006, this percentage rose from $13 \%$ to $25 \%$. ${ }^{19}$ These loans enabled the borrower, for some fixed period, to choose how much of a payment he or she would make. Often this payment was less than the accruing interest and the deficiency in interest payment was added to principal. Thus, the loan would become a negative amortization loan, that is, one in which the principal owed is rising over time. Contrast this with a standard loan in which the payment not only covers interest but also reduces the principal balance.

This type of loan was initially designed for a sophisticated borrower who understood the risk and knew there was no Santa Claus. However, as housing prices rose, lenders began marketing this type of loan to lower income borrowers as an "affordability" $\operatorname{loan}^{20}$ that would enable a borrower to buy a more expensive house than the borrower could afford if the mortgage payment were determined under a standard amortized loan.

The other product that replaced the fixed rate Alt-A was the adjustable rate Alt-A loan. From 2000 to 2003 , the loans steadily increased from about $14 \%$ to $25 \%$. However, they rose to over $60 \%$ in 2004 to 2006. Thus, the number of Alt-A loans increased even more explosively than the subprime loans and, like the subprime loans, as their numbers increased so did their risk characteristics as more and more loans were adjustable rate or pic-a-pay loans.

If the foregoing analysis is correct, one would expect that the delinquency, default and foreclosure rates (the "default rates") for loans would increase for annual cohorts of loans from 2000 to 2006 and that the loan types which this article asserts as the riskiest would have the highest default rates. That is exactly what the data has demonstrated.

The default rate for fixed rate subprime mortgages dropped from $23 \%$ in 2000 to $11 \%$ in 2003 , but then rose from $16 \%$ in 2004 to $32 \%$ in $2006 .^{21}$ The default rate for hybrid ARMs dropped from $23 \%$ in 2000 to $13 \%$ in 2003, but then rose from $17 \%$ in 2004 to $50 \%$ in 2006 . A similar pattern existed for Alt-A loans. The default rate for fixed rate Alt-A loans was $8 \%$ in 2000 and averaged less than 5\% for

\footnotetext{
${ }^{17}$ GAO Report, supra note 13 , at 5.

18 With this type of loan, the borrower could choose a payment amount that was substantially below the accruing interest rate, with the deficiency in accrued interest added to principal. When these loans reset, the mortgage payment could triple. See Edmiston supra note 14, at 13.

${ }^{19}$ GAO Report, supra note 13 , at 26, tbl 5.

${ }^{20}$ GAO Report, supra note 13 , at 12-13.

${ }^{21}$ GAO Report, supra note 13, at 35-36 enclosure III, tbl 10. The percentage used in this section for default rate is the sum of percentages for mortgages that are delinquent, that are in default, that are in the foreclosure process, and that have completed the foreclosure process. The higher default rate in 2000 is probably attributable to the bursting of the dot-com bubble.
} 
the next three years. ${ }^{22}$ In 2004-2006, the default rate rose from $4 \%$ to $13 \%$ to $23 \%$ for fixed rate alt-A loans. With respect to payment-option loans, the default rate averaged less than $1 \%$ in $2000-2002$, when they were used by sophisticated borrowers. From 2003 to 2006, the default rates increased from $4 \%$ to $8 \%$ to $22 \%$ to $37 \%$ in 2006 . These was a similar pattern of increased default rates for adjustable Alt-A mortgages in 2004 thru 2006, which contrasted with an average default of about 4\% from 2000 to 2003.

Thus, there is a clear pattern that the default rates for annual cohorts of mortgages increased over time and particularly from 2004 to 2006 . There is a second clear pattern which shows that the default rates for the riskier mortgages increased faster than the default rates for the fixed mortgages. This continued into 2007.

Since the critical period is 2004-2007, there are two major questions: who were the major players involved in producing these risky mortgages and what drove them to take such risk.

\section{Who Was Responsible for These Risky Loans, What Drove Their Actions, And to What Extent Will the Financial Reform Act Prevent a Future Crisis?.}

It is already been posited that the overarching driver of the subprime crisis was the explosion in assets under investment looking for a home. However, it is difficult to assess culpability on the investors when they were buying a security with a triple A credit rating from the rating agencies and through a prospectus which did not adequately alert them to the dangers of the investment. Accordingly, the following material will examine the cast of participants involved in bringing the loan to the investor. These include the borrower, the mortgage broker, the mortgage banker, the syndicator of the security [generally either a government-sponsored entity or an affiliate of an investment banker], the rating agencies, and the issuers of derivatives.

A. Fatal Flaws in the Origination of Toxic Mortgages: the Roles of the Borrower, the Mortgage Broker and a Mortgage Lender, and the Curative Impact of the Financial Reform Act

1. The borrower: opportunist or victim?

The borrower is often pictured either as an unscrupulous opportunist, who sought to cash out some of the inflated value of his home or to buy a property beyond his means, or a victim of avaricious businesses who euchred him into a transaction that he did not understand. The data, often anecdotal, suggest that there is truth to both tales, as well as many situations falling on a continuum in between. There undoubtedly were borrowers who sought to game the system. ${ }^{23}$ On the other hand, there is no

\footnotetext{
${ }^{22}$ Default rates in the period 2000-2003 are generally highest in the 2000 cohort of loans. This may be related to the dot com bubble bursting in 2000. Banks which originated mortgages in 2000 may have found that the income and assets upon which they relied shrank when the bubble burst.

23 A tattoo-parlor owner, known as Sonny, made ninety sales in about four years, often using strawmen buyers who received a small slice of the mortgage proceeds, put no money down and then disappeared and were untraceable. He cleared \$4 million. Sonny's deals were financed by Wachovia, Wells Fargo, Washington Mutual, Bank of America, Lehman Brothers, Fannie Mae, and Freddie Mac, who obviously did little due diligence. Matthew Haggman \& Jack Dolan, Probe of Broker Agency Is Sought, MiAMI HeRALD, July 29, 2008, at 85, available at http://www.miamiherald.com/1060/story/787362.html.
} 
doubt that there was incredible selling pressure brought to bear upon prospective borrowers. ${ }^{24}$ What would induce mortgage brokers to go out into the hinterlands to find prospective mortgagors? That is a subject for the next section. But first let us examine the incentives for borrowers to enter into risky transactions.

At one end of the spectrum, some degree of opportunism lurks in all of us. Combined with optimism, there is frequently a tendency to stretch to move up in the housing market, particularly when prices are rising and there is the fear of being left behind. When offered the so-called 2/28 or 3/27 adjustable rate mortgage, there is a tendency to focus upon being able to afford the payment predicated upon the teaser rate, rather than the sobering reality of being able to make the principal payment when the mortgage resets. So how do you deal with opportunistic optimism? There is a serious question as to whether $2 / 28$ or $3 / 27$ mortgages have a place in the financing system for home mortgages, at least below a certain threshold of income. This is not to suggest that there is a correlation between income and intelligence, but rather that there is a correlation between income and sophistication, namely the ability to appreciate risk.

Do we need more regulation here? A good case can be made that naïve regulation has complicated the task of being able to decipher the economics of a proposed mortgage. As one commentator stated, "Most of us have experienced being overwhelmed and befuddled by the huge stack of documents full of confusing language in small print presented to us at a mortgage closing. These documents are the result of legal and compliance requirements, including regulatory attempts to insure disclosure." 25 What is needed is a one-page mortgage summary sheet which, among other information, would give the borrower the current interest rate and mortgage payment and the maximum reset interest rate and corresponding monthly payment. ${ }^{26}$

How many borrowers find the mortgage documentation to be confusing? The Milken Institute, relying on Federal Trade Commission data, found that $87 \%$ of respondents could not identify the total up-front cost of the loan, $51 \%$ could not identify the loan amount from the documents, and $30 \%$ could not identify the presence and amount of a balloon payment. ${ }^{27}$ Regulation should not encourage pages of boilerplate disclosure, but rather meaningful disclosure. There is often a wide gap in sophistication between the borrower and the providers of credit. In this context, complexity works to deceive the borrower.

But what of the borrowers who were unscrupulous opportunists? As the subprime market developed in the mid-2000s, prospective borrowers were encouraged to be unscrupulous by the

\footnotetext{
${ }^{24}$ Even today, as I was writing this article, I received a text message soliciting me to refinance my mortgage. Being financially ultraconservative and risk-averse, I am an unlikely candidate.

${ }^{25}$ See Alex J. Polack, After the Subprime Lending Bust, AM. ENTERPRISE INST. For PUB. POL'Y RES., May 15, 2007, http://www.aei.org/publications/pubID.26179/pub_detail.asp.

${ }^{26}$ The Polack Prototype, AM. ENTERPRISE InST. FOR PUB. POL'Y RES., http://www.aei.org/docLib/20070515_PollockPrototype.pdf (last visited Oct. 7, 2009).

${ }^{27}$ See Milken Institute, Demystifying the Mortgage Meltdown: What it Means for Main Street, Wall Street and the U.S. Financial System, Oct. 2, 2008.
} 
explosion of the so-called liars' loans. These loans evolved from stated income loans, in which the borrower did not need to document income, and which made some sense for a self-employed person, ${ }^{28}$ into "stated asset" loans, in which the borrower need document neither income nor assets. As one lender stated: "So I don't really need to know what you make. I don't need proof. You tell me you make $\$ 200,000$ a year? You make \$200,000 a year."29 The Internet was alive with mortgage brokers and mortgage lenders offering stated income and stated asset loans. ${ }^{30}$ For those at the unscrupulous end of the spectrum, it is hard to conceive of a better incentive to fabricate personal financial data than the broad-based solicitation of liars' loans.

One way to take the incentive out of lying is a criminal prosecution for fraud. Unfortunately, as the next section illustrates, it often is not clear whether the borrower unilaterally lied, whether the borrower lied with the explicit or tacit encouragement of the broker or lender, as illustrated in the preceding paragraph, or whether the broker or lender itself falsified the documents. Today the business sector is overwhelmed by the problems of liars' loans. The criminal system has far less resources and, with proof beyond a reasonable doubt required, has little incentive to prosecute "he said, she said" type cases. $^{31}$

Looking forward, why should a financial institution ever make a loan without verified documentation as to income and assets? Even with self-employed persons, there should be state and federal income tax returns and estimated tax payments on the income side. Just because it is not possible to obtain some of the documentation that would be available to an employee is no justification for not seeking any documentation. With respect to assets, status as a self-employed person has no impact whatsoever on the ability to disclose assets. Moreover, disclosure of assets, such as bank accounts, may well provide correlation to income disclosure. Thus, tightening lending standards and requiring documentation is a simple way to eliminate liars' loans.

\section{The mortgage broker}

One of the culprits in the subprime crisis was the mortgage broker. Mortgage brokers clearly were incentivized to make loans, since the commission was paid upfront, often out of the points charged. While an honest broker might charge a commission of around $1 \%,{ }^{32}$ unscrupulous brokers charged fees

\footnotetext{
${ }^{28}$ The early rationale for these loans was that some borrowers, such as self-employed persons, could not provide income verification because of the lack of documents such as W-2s.

${ }^{29}$ See 60 Minutes, House of Cards: The Mortgage Mess, (CBS television broadcast May 25, 2008).

${ }^{30}$ Googling "stated income loans" produces over 1 million responses, many of which are offering such loans.

${ }^{31}$ Laws of New York, 2008, ch. 472, introduces a new Article 187, "Residential Mortgage Fraud," to the New York State Penal Code.

${ }^{32}$ Rick Brooks \& Ruth Simon, Subprime Debacle Traps Even. Credit-Worthy, WALL St. J., Dec. 3, 2007, available at http://online.wsj.com/article/SB119662974358911035.html ("On average, U.S. mortgage brokers collected 1.88\% of the loan amount for originating a subprime loan, compared with $1.48 \%$ for conforming loans, according to Wholesale Access, a mortgage research firm.")
} 
ranging up to $5 \%$ or higher. ${ }^{33}$ A $5 \%$ commission on a $\$ 200,000$ loan would produce a fee of $\$ 10,000$. Not a bad days' work! Six-figure incomes were typical, ${ }^{34}$ and some brokers made upwards of \$1 million a year. ${ }^{35}$ One mortgage research organization reported that, at the end of 2006, the average monthly volume of a mortgage broker was $\$ 1.6$ million. ${ }^{36}$ At a $11 / 2 \%$ fee, this would produce a monthly income of $\$ 24,000$ a month or $\$ 288,000$ annually.

While this compensation may seem exceptional to some, salesmen are often compensated by commissions and, in some non-public companies, a salesman could make more than the CEO. The purpose of paying on a commission basis is to incentivize performance, namely, generate sales. The problem is not compensation in the abstract, but rather whether the broker is acting ethically and whether the amount of compensation incentivizes brokers to engage in fraud, or act in a manner antithetical to the interests of the borrower.

The term broker is ambiguous. When the broker tells a prospective borrower that he can get the borrower the "best" mortgage for the borrower, the borrower would understand that the broker is acting for the borrower's benefit. In other words, the borrower would expect that the broker is the agent of the borrower. In such case, the broker has fiduciary duties, including duties of full disclosure of all material aspects of the transaction, as well as the compensation of the broker. ${ }^{37}$ And of course, the broker has an obligation not to deceive or defraud the borrower.

In response to the subprime crisis, California, ${ }^{38}$ and New York and Illinois, in 2008 passed legislation that would, in effect, legislatively impose fiduciary duties on mortgage brokers. In California, Gov. Schwarzenegger vetoed the legislation, in part because of his concern that the legislation covered independent brokers but not employees of the lender, and part over the ability of

33 See Better Business Bureau, Beware of Predatory Practices in Whole Mortgage Lending, Apr. 12, 2002, http://www.bbb.org/us/article/beware-of-predatory-practices-in-home-mortgage-lending-265 ("In the sub-prime market, there are mortgage brokers who will attempt to sell the borrower on a loan with the most fees and highest interest rate possible so that he/she will get more compensation. Some of these brokers may charge fees of 8 to 10 points. That means that on a $\$ 100,000$ loan, the borrower is paying and financing an additional \$8,000 to \$10,000"). See also Socialservice.com, Predatory Mortgage Lending, http://www.socialserve.com/tenant/PredatoryLending.html (last visited Oct. 7, 2009).

${ }^{34}$ See Effect of Subprime Mortgage Lending on Mortgage Brokers, http://www.subprimelendingcrisis.com/Effect_of_Subprime_Mortgage_Lending_on_Mortgage_Brokers.php.See also Peter

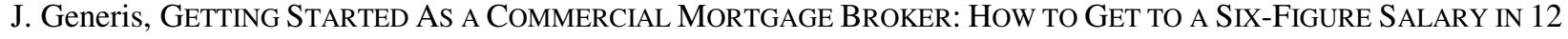
MONTHS (2008).

35 Judge Thomas L. Perkins, The Origins of the Subprime Mortgage Crisis, ATTY's TITLE GUARANTY FUND, INC.: THE TRUSTED ADVISER, Oct. 2008, available at http://www.atgf.com/AllAttorneys/ATGNewslettersArchive/TheTrustedAdviser/tabid/459/Default.aspx.

36 See Monthly Broker Surveys: Jan. 2009 Monthly Broker Report, Access Mortgage Research \& Consulting, Inc., http://wholesaleaccess.com/?page_id=50

${ }^{37}$ See Restatement (Third) of Agency $§ 8.01$, General Fiduciary Principle.

${ }^{38}$ A summary of the California legislation can be found at http://democrats.assembly.ca.gov/members/a53/pdf/AB1830.pdf (last visited Oct. 9, 2009). 
borrowers to obtain attorneys fees. ${ }^{39}$ However, Gov. Paterson signed the New York legislation. Among other things, this legislation would require each mortgage broker to:

(a) act in the borrower's interest;

(b) act with reasonable skill, care and diligence;

(c) act in good faith and with fair dealing;

(d) not charge any undisclosed compensation, directly or indirectly;

(e) clearly disclose all material information that affects the borrower's interests; and

(f) diligently work to present the borrower with a range of loan products for which the borrower likely qualifies and which are appropriate to the borrower's existing circumstances, based on information obtained in good faith by, the broker.

The Illinois legislation, championed by Atty. Gen. Lisa Madigan, contains similar provisions. ${ }^{41}$ It also gives borrowers a private right of action and requires verification of the borrower's reasonable ability to service the mortgage. ${ }^{42}$

Placing a borrower in a $2 / 28$ or $3 / 27$ teaser loan, which could reset into a mortgage payment that would double or more, ${ }^{43}$ generally would not be in the borrower's best interest, unless full disclosure of the risks involved and the scope of the potential reset were made to the borrower. Nor would steering the borrower into a subprime loan be in the borrower's best interest, when the borrower could qualify for a conventional loan. A study commissioned by the Wall Street Journal found that, in 2005, 55\% of the subprime borrowers had credit scores generally high enough to qualify for conventional loans with far better terms. In 2006, the proportion was even higher, namely, $61 \% .{ }^{44}$ While there is some softness with respect to what credit score is sufficient to get conventional financing -- generally over 620 -- during the period 2004 to 2007 about one-eighth of the subprime borrowers had credit stores over 700, clearly sufficient for conventional financing. 45

What drove mortgage brokers to place qualified buyers in subprime loans? Very likely, the increased commissions that are generated in the subprime market. On many subprime mortgage loans, brokers receive a kickback from the lender known as a "yield spread premium." Basically, the lender offers a wholesale rate and the broker quotes a retail rate to the borrower, which can be a point or two

\footnotetext{
39 The first reason that Gov. Schwarzenegger gave for vetoeing a bill was that "its provisions will only apply to state regulated entities, as federally regulated entities will be exempt." However, the federal government does not regulate mortgage brokers. Thus, the governer must have been referring to lenders that are regulated by the federal government. But most subprime lenders were "non-banks" that were not regulated by the FDIC. Gov. Arnold Schwarzenegger, Address Regarding Assembly Bill 1830, http://gov.ca.gov/pdf/press/AB_1830_Lieu_Veto_Message.pdf (last visited Oct. 9, 2009).

${ }^{40}$ Laws of New York, 2008, ch. 472, amending the New York State Banking Law to add a new section 590-b. Illinois adopted similar legislation. See P.A. 95-691, available at http://www.ilga.gov/legislation/publicacts/95/PDF/095-0691.pdf.

${ }^{41} 205$ ILCS 635/5-7.

42 205 ILCS 635/4-16, 5-7.

${ }^{43}$ See Edmiston \& Zalneraitis, supra note 14, at 13-14.

${ }^{44}$ See Brooks \& Simon, supra note 32.

${ }^{45} I d$. (interactive graphic).
} 
higher and, in some cases, substantially higher. The higher the interest rate, the more the broker gets paid. Professor Elizabeth Warren of Harvard has estimated that $85 \%$ to $90 \%$ of subprime loans involved a yield spread premium. ${ }^{46}$ She opined that a borrower, who could qualify for a $6.5 \%$ fixed-rate 30 year mortgage, could end up with a $9.5 \%$ variable mortgage. While this is clearly to the disadvantage of the borrower, it provides substantial increase in compensation to the mortgage broker.

Regulation of mortgage brokers varies widely across the country. In Florida, more than 10,000 convicted criminals worked in the mortgage business, thousands of whom were licensed brokers. ${ }^{47}$ One Congresswoman observed that Florida was particularly lax when it came to mortgage regulation, and she connected the lack of oversight with state politics and the political clout of developers. ${ }^{48}$

The potential to make huge sums of money motivated some mortgage brokers to falsify documentation and even create bogus transactions. ${ }^{49}$ National Public Radio detailed a situation in which a mortgage application was filled out by the mortgage broker and listed the borrower's income at $\$ 16,250$ a month, or almost $\$ 200,000$ a year. The borrower's actual income was $\$ 37,000$ and he had provided the broker with his tax returns. The broker's fee was $\$ 18,500 .{ }^{50}$ The borrower would have qualified for a VA loan, but instead was placed in an adjustable rate subprime loan. When the loan reset, the borrower's payments increased by $\$ 2,000$ a month.

Such action should be criminal. In fact, mortgage fraud prosecutions are ongoing around the country. ${ }^{51}$ Recently, forty-one defendants were charged in one of the largest mortgage fraud schemes in the country. ${ }^{52}$ The mastermind of the scheme allegedly pocketed $\$ 31$ million through bogus mortgage loans by bringing in buyers and helping them falsify credit applications to obtain loans. But, as

${ }^{46}$ Elizabeth Warren, Mortgage Brokers Sleight of Hand, THE BOSTON GLOBE, Oct. 2, 2007, available at
http://www.boston.com/business/personalfinance/articles/2007/10/02/mortgage_brokers_sleight_of_hand/. Michael Calhoun, president of the Center for Responsible Lending which had been trying for over a decade to get regulators to outlaw yield spread premiums, analyzed the incentive for brokers to engage in this practice: "People didn't just happen to end up in risky loans. Mortgage brokers and other people on the front lines were getting two to three times as much money to push buyers into those loans than they were into 30-year fixed-rate loans. So what do you think happened?" David Streitfeld, Fed Adopts Rules Meant to Protect Homebuyer, N.Y.TiMES, AUG. 17, 2010, Available at http://www.nytimes.com/2010/08/17/business/17mortgage.html?src=me\&ref=business.

${ }^{47}$ Matthew Haggman \& Jack Dolan, Probe of Broker Agency Is Sought, MiAMi HERALD, July 29, 2008, available at http://www.miamiherald.com/1060/story/787362.html; see also George Packer, The Ponzi State, THE NEW YORKER, Feb. 9, 16,2009 , at 81,84 .

${ }^{48}$ Haggman \& Dolan, supra note 47 , at 84-85.

${ }^{49}$ One mortgage broker, just out of college, made \$75,000-\$100,000 a month. This American Life: The Giant Pool of Money, Chicago Public Radio Broadcast (May 9, 2008), available at http://www.thislife.org/extras/radio/355_transcript.pdf.

${ }^{50} \mathrm{Id}$.

${ }^{51}$ See Mortgage Fraud Blog, Jan. 9, 2007, available at http://www.mortgagefraudblog.com/index.php/weblog/permalink/colorado_mortgage_prosecution_results_in_four_guilty_pl eas/, and The Mortgage Fraud Reporter, Oct. 1, 2009, available at http://www.mortgagefraud.org/,

${ }^{52}$ Ohio Att'y Gen. News Rel., Task Force Cracks Mortgage Fraud Case Involving 453 Homes, Aug. 26, 2009, Available at http://www.ohioattorneygeneral.gov/getdoc/6a43f62e-1fc6-4c3c-9809-d3985f210275. 
observed in the preceding section, the criminal system does not have the resources to deal with this problem. The goal should not be prosecution, but rather prevention. That is why it is essential that documentation be required and verified.

\section{The mortgage lenders}

It does not take a rocket scientist to decipher the incentive for mortgage lenders to ratchet up subprime lending to satisfy the market demand for mortgage backed securities. More loans meant more revenue, which translated into greater earnings and higher stock prices and, of course, greater compensation for management. Coupled with this was the seeming lack of risk when loans can be packaged and sold to underwriters without recourse. Set forth below is a graph of the stock prices for Countrywide Financial from 2000 to $2008 .^{53}$

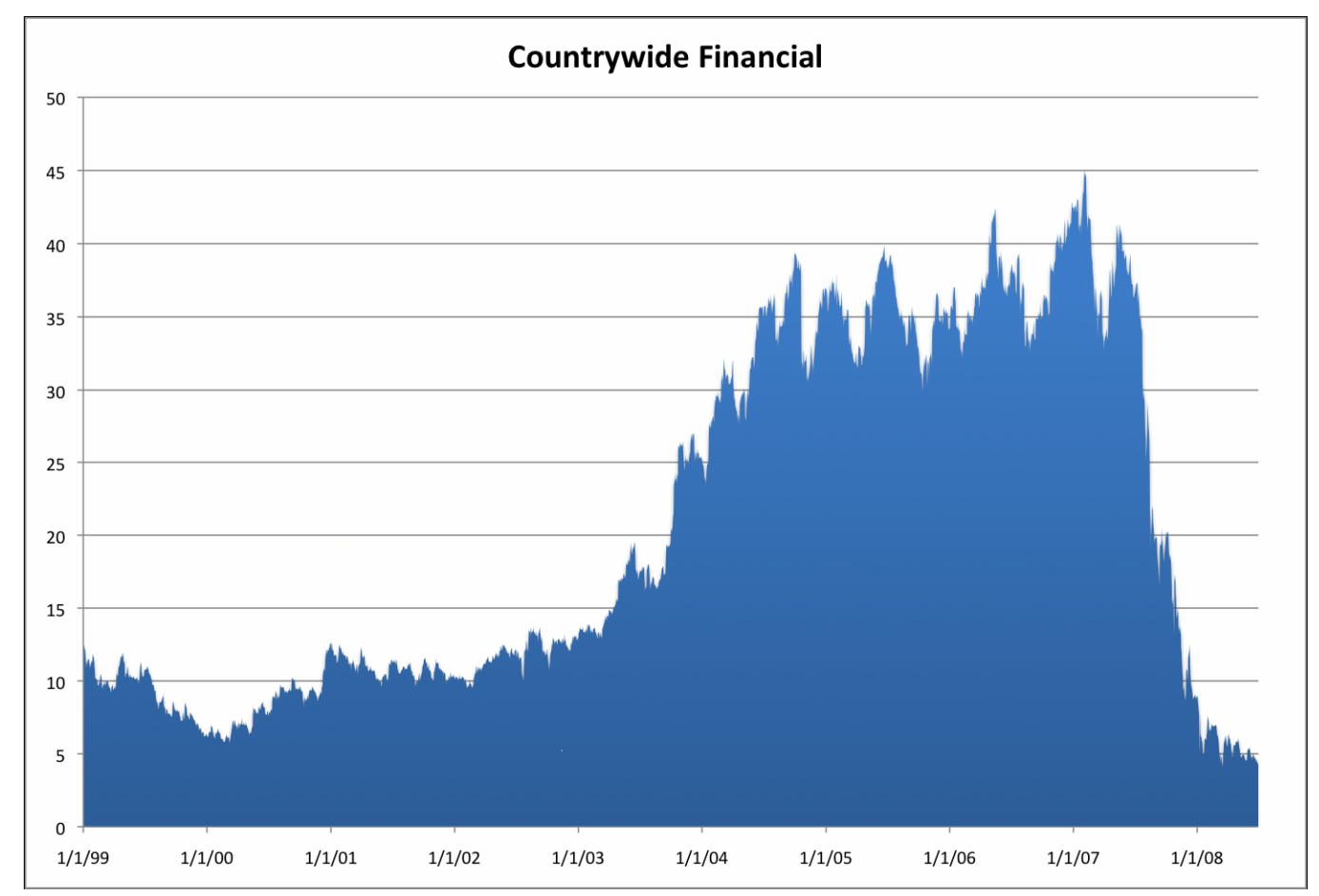

Up to 2003, Countrywide was mainly making conventional 30 year fixed-rate mortgages. Mortgages for securitization were mainly sold to the GSE's, ${ }^{54}$ as the investment banks were not major players. ${ }^{55}$ But

\footnotetext{
${ }^{53}$ Since Countrywide Financial is no longer publicly traded, this graph was developed from data available from Thomson Reuters "Datastream." The code for Countrywide is 916036.

${ }^{54}$ Government Sponsored Entities

${ }^{55}$ See Part II, supra.
} 
Countrywide then got heavily into the subprime business ${ }^{56}$ When Countrywide started producing riskier products, loan volume, revenues, earnings, and executive compensation all increased, paralleling the increase in stock prices. See the chart below. ${ }^{57}$

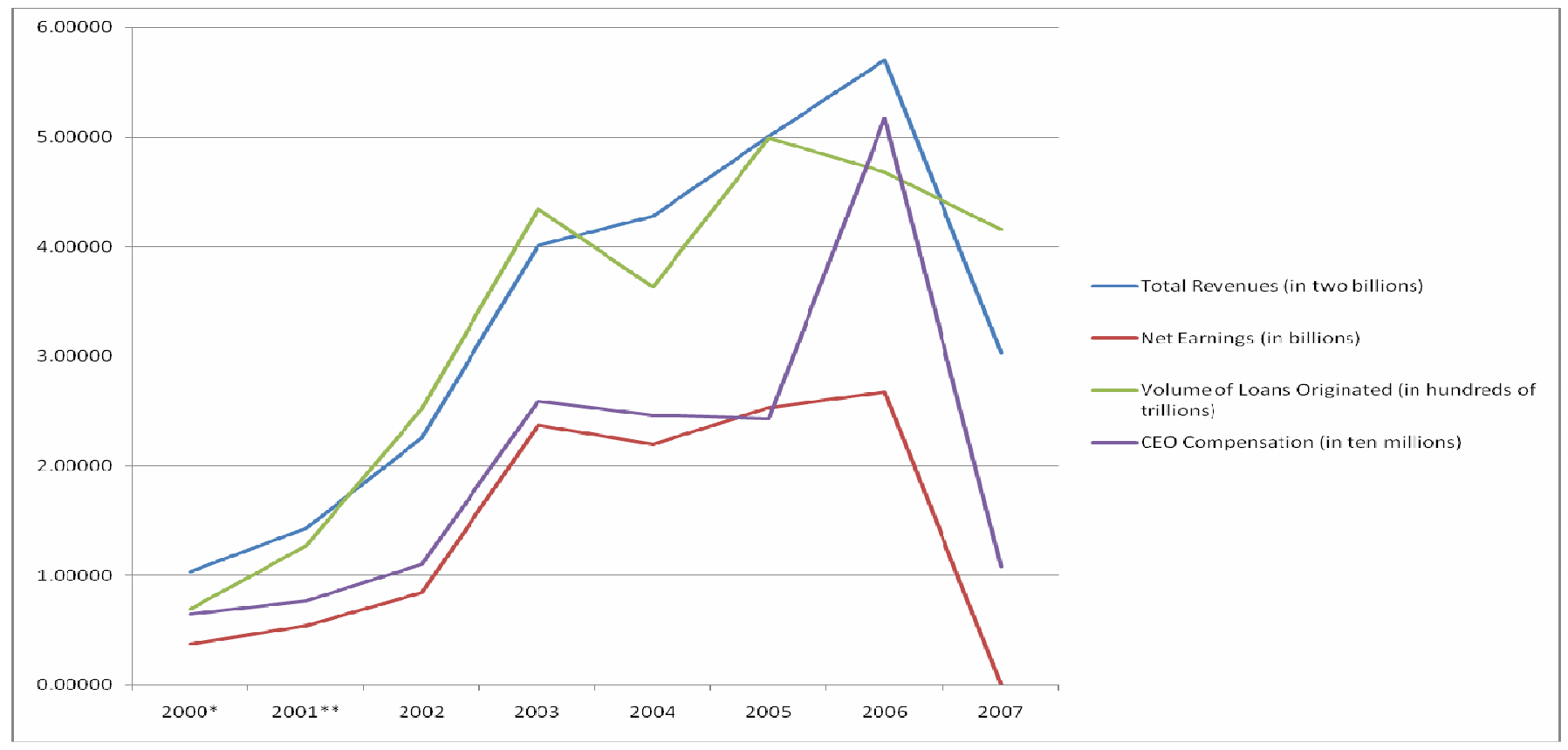

The two charts above essentially demonstrate the correlations between the venture into risky lending practices, generating increased volume and earnings, and thereby hyping the stock price and increasing the compensation for Andrew Mozilo, the CEO of Countrywide.

Much of Mr. Mozilo's income was attributable to stock options. This form of incentive compensation is supposed to align the interests of management with that of the stockholders. However,

\footnotetext{
${ }^{56}$ See E. Scott Reckard \& Annette Haddad, Credit Crunch Imperils Lender, L.A. Times, Aug. 16, 2007, available at http://www.latimes.com/news/local/la-fi-countrywide16aug16,0,6834329.story?page=2 (quoting Bill Dallas, an executive at Ownit Mortgage, which also failed).

${ }^{57}$ The above chart is based on data in Countrywide Financial Corporation's Form 10-K for fiscal year ended December 31, 2007, Form 10-K/A for fiscal year ended December 31, 2007, Form 10-K for fiscal year ended December 31, 2002, Schedule 14A filed April 29, 2002, and Schedule 14A filed June 8, 2001. These documents are available under CIK \# 0000025191 at www.sec.gov. The Chart is developed from the following table of data:
}

$\begin{array}{rrrrr} & \text { Total Revenues } & \text { Net Earnings } & \text { CEO Compensation } \\ 2000 & 2,073,839,000 & 374,153,000 & 68,923,000,000 & 6,476,604 \\ 2001 & 2,860,359,000 & 537,541,000 & 126,980,000,000 & 7,682,302 \\ 2002 & 4,519,466,000 & 841,779,000 & 251,901,000,000 & 11,041,852 \\ 2003 & 8,026,846,000 & 2,372,950,000 & 434,864,000,000 & 25,925,941 \\ 2004 & 8,566,627,000 & 2,197,574,000 & 363,364,000,000 & 24,642,098 \\ 2005 & 10,016,708,000 & 2,528,090,000 & 499,301,000,000 & 24,350,342 \\ 2006 & 11,417,128,000 & 2,674,846,000 & 468,172,000,000 & 51,755,223 \\ 2007 & 6,061,437,000 & -703,538,000 & 415,634,000,000 & 10,812,297\end{array}$


this conventional wisdom has a fatal flaw in that it does not take into account the risk profile of the two groups. Shareholders have a sunk economic stake in their stock investment, and a risk profile that is more conservative than management's. When management takes on increased risk, the stockholders can gain handsomely or lose all. On the other hand, when management is given options together with $\$ 1$ million salary, taking risk can pay off handsomely if gains ensue. If the loans eventually turn out badly, the executive holding options, unlike the long-term shareholder investor, has no sunk investment to lose. But, if the increased risk drives up profits in the short term, with a corresponding increase in the price of the stock, the benefit to management can be enormous, since management can exercise their options and sell the stock before the bottom falls out.

In the case of Countrywide, the price of the stock quadrupled from 2002 to 2005. Mr. Mozilo sold \$130 million of Countrywide in 2007 before the market for Countrywide stock plummeted and was later charged with fraud. ${ }^{58}$ Through stock options, Mozilo could buy cheaply and sell at the peak. This gave him an incentive of hundreds of millions of dollars to take the risks that ultimately brought the company down.

On the other hand, investors were not privy to the inside information Mr. Mozilo had. According to FOXBusiness, "Countrywide portrayed itself as underwriting mainly prime-quality mortgages, using high underwriting standards. But concealed from shareholders was the true Countrywide, an increasingly reckless lender assuming greater and greater risk., ${ }^{, 59} \mathrm{Mr}$. Mozilo's attorney asserted that he was not aware of the problems with Countrywide's loan portfolio, but FOXBusiness released a series of his e-mails in which Mozilo recognized the "toxic" nature of the loans. ${ }^{60}$ When the stock of Countrywide plummeted, it was the investors who lost their sunk investment.

After Bank of America acquired Countrywide, it paid $\$ 8.6$ billion to settle lawsuits brought by the attorneys general of eleven states based on Countrywide's predatory lending practices. ${ }^{61}$ Apparently, one of the reasons that Gov. Schwarzenegger vetoed the California legislation was that it would have imposed fiduciary duties upon mortgage brokers, but not apply to mortgage lenders. ${ }^{62}$ In point of fact, legislation is needed not just to impose fiduciary duties upon mortgage brokers but also to impose

\footnotetext{
${ }^{58}$ See Kara Scannell \& John R. Emshwiller, SEC Poised to Charge Mozilla with Fraud, WALL ST. J., May 14, 2009, available at http://online.wsj.com/article/SB124224647957816523.html ("Mr. Mozilo sold \$130 million of Countrywide stock in the first half of 2007 under an executive sales plan, according to securities filings, compared with $\$ 60$ million in the year-earlier period. He had modified his prearranged plan in late 2006 to accelerate the sales.”) According to FOXBusiness, "Mozilo was widely criticized for selling some Countrywide stock for $\$ 140$ million in profits by exercising 5.1 million options and selling the underlying shares -- in 2006 and 2007, just as the mortgage market topped out." Peter Barnes \& Joanna Ossinger, Countrywide Ex-CEO Angelo Mozilo Charged with Fraud, FOX BUSINESS, June 4, 2009, available at http://www.foxbusiness.com/story/markets/countrywide-ceo-mozilo-charged-fraud/.

${ }^{59}$ See Barnes \& Ossinger, supra note 58 (quoting SEC Enforcement Director Robert Khuzami.).

${ }^{60} I d$.

${ }^{61}$ See BofA in \$8.6 bln Settlement over Countrywide Loans, REUTERS, Oct. 6, 2008, available at http://www.reuters.com/article/regulatoryNewsFinancialServicesAndRealEstate/idUSBNG28749420081006

${ }^{62}$ See supra note 39.
} 
similar responsibilities upon lenders and their employees. It is equally serious for the lender to misrepresent the terms of the transaction or to induce borrowers to enter into mortgages which they cannot afford.

By way of illustration, one of the subprime lenders, was subjected to a cease-and-desist order by the FDIC which required the lender not to make mortgage loans without adequately considering the borrower's ability to repay the mortgage. In particular, the lender was enjoined from qualifying borrowers for loans with low initial payments based on an introductory rate that would expire after an initial period without an adequate analysis of the borrower's ability to repay the debt at the fully-indexed rate; approving borrowers without considering appropriate documentation and/or verification of their income; providing borrowers with inadequate and/or confusing information; approving loans with inadequate debt-to-income analyses that did not properly consider the borrowers' ability to repay; and approving loans with loan-to-value ratios approaching or exceeding 100 percent of the value of the collateral. $^{63}$

Subprime lenders share a similarity with a mortgage brokers. Both the mortgage brokers and the subprime lenders receive substantial upfront fees, enabling them to realize income at the front end, without waiting for the borrower to begin making mortgage payments which would translate into interest income on an ongoing basis. In the abstract, there is nothing wrong with a lender charging points and other reasonable upfront fees. But the availability of upfront fees accelerates income to the lender and provides an incentive for the lender to be less concerned about the credit worthiness of the borrower.

Of the top twenty-five subprime lenders in 2006-2007, only five are still in the lending business; the large majority, like Countrywide, are now either insolvent or have been bought out at distressed prices. ${ }^{64}$ Many of these subprime lenders were "non-banks", that is, they did not accept deposits. Accordingly, they were not regulated by the FDIC. Since depositors were not providing the funds for these mortgage banks to loan, their funding came in the way of lines of credit and other arrangements with the major investment banks and commercial banks. The role of the investment banks in funding these non-banks will be considered in a later section.

\section{The Response of the Financial Reform Act to the Creation of Toxic Mortgages}

While critics of the Financial Reform Act decry that the legislation involves governmental intrusion into business and will stifle the economy, the foregoing analysis demonstrates that we have not been able to rely upon the mortgage industry to determine whether a borrower has the capacity to make the required loan payments. Liar's loans should never have existed. As discussed earlier, some sort of documentation always exists; the reason it was not sought was that brokers and lenders were indifferent as to whether the loan would be repaid: loans were created to be sold and the originator had "no skin in the game."

\footnotetext{
63 FDIC Cease and Desist Order, Docket No. FDIC-07-035b, available at http://www.fdic.gov/bank/individual/enforcement/2007-03-00.pdf (last visited Oct. 9, 2009).

${ }^{64}$ See Who's Behind the Financial Meltdown?, The Center for Public Integrity, May 6, 2009, available at http://www.publicintegrity.org/investigations/economic_meltdown/
} 
Had the Financial Reform Act been in place at the turn of this century, the subprime crisis probably would not have occurred. However, whether the legislation goes far enough to prevent future crisis is less clear.

Subtitle B of Title 14 of the Financial Reform Act creates minimum standards for residential loan mortgages by amending the Truth in Lending Act to add a new section 129C which would prohibit lenders from making a loan unless the lender (i) "makes a reasonable and good faith determination" that is (ii) "based on verified and documented information" that the consumer "has a reasonable ability to repay the loan"; including (iii) "taxes, insurance (including mortgage guarantee insurance), and assessments." $" 65$ Thus, in one short sentence, this new provision has three elements that, if lenders had utilized in the past, the subprime crises could have been averted. It requires verified information that supports a reasonable belief that the customer can make the mortgage payments including, not just principal and interest, but also taxes, insurance and assessments. One would think that these requirements would be a no-brainer; unfortunately, mortgage brokers and lenders were financially incentivized to ignore common sense.

The new Act also makes clear that the obligation to determine ability to pay is based upon a payment schedule "that fully amortizes the loan over the term of the loan."66 In calculating the payment, the interest rate over the entire term of the loan is to be "a fixed rate equally to the fully indexed rate at the time of closing without considering the introductory rate." ${ }^{67}$ Thus, for the so-called 2/28 or 3/27 mortgages with an initial low teaser rate, the ability to pay cannot be predicated upon the initial mortgage payment based upon the teaser rate. As discussed earlier, it was the resetting of the teaser rate, with a resulting monthly payment that could double or triple the original payment, that led to many mortgage defaults.

In the case of interest-only loans or pic-a-pay loans with a negative amortization, there are specific provisions that require the ability to pay to be predicated upon a fully amortizing repayment schedule. ${ }^{68}$ Thus, the ability to repay cannot be finessed by assuming that the buyer has the option of not paying interest and just adding the interest to the ultimate principal. This provision also would have barred many of the improvident loans that ultimately defaulted. Pic-a-pay loans are another "financial innovation" that helped innovate the economy into a financial meltdown.

In the case of $2 / 28$ or $3 / 27$ loans, which the Act defines as a "hybrid adjustable rate mortgage," six months before the reset, the creditor or servicer of the loan must furnish the borrower with a notice that includes the basis for the reset, a good faith estimate of the new monthly payment, a list of alternatives such as refinancing or pre-foreclosure sale, and the names and contact information of consumer counseling agencies. ${ }^{69}$ This is designed to give the borrower a sufficient time frame to adjust to the higher payments or to make alternative arrangements.

\footnotetext{
${ }^{65}$ H.R. 4173, § 1411,

${ }^{66} I d$. (adding $\S 129 \mathrm{C}(\mathrm{a})(3)$.)

${ }^{67}$ Id. (adding $§ 129 \mathrm{C}(\mathrm{a})(6)(\mathrm{D})(\mathrm{iii})$.)

${ }^{68}$ Id. (adding § 129C(a)(6)(A)-(C).)

${ }^{69}$ H.R. 4173. $§ 1418$.
} 
The new legislation not only would have effectively barred many improvident loans, but also restricts some of the incentives that led to such loans. In particular, the new legislation would bar yield spread premium or other compensation "based on the terms of the loan (other than the amount of the principal)., ${ }^{, 70}$ What this basically means is that the compensation of a broker cannot be a function of inducing the customer to enter into a more expensive loan. Many subprime borrowers could have qualified for a conventional loan, but mortgage brokers put them into a more expensive loan because of the higher fees the subprime loans generated.

A mortgage originator is defined as a person who takes a residential mortgage loan application, or assists the customer in obtaining or applying for such a loan, or offers or negotiates the terms of such a loan. ${ }^{71}$ Thus, the term would include both a broker and a lender. In general, an originator cannot steer a customer to a loan which he or she does not have the ability to repay or which is predatory in nature. ${ }^{72}$ An originator also cannot "(i) mischaracterize the credit history of a consumer or the residential mortgage loans available to the consumer; (ii) mischaracterize or suborn the mischaracterization of the appraised value of the property securing the extension of credit; or (iii) if unable to suggest, offer, or recommend to a consumer a loan that is not more expensive than a loan for which the consumer qualifies, discourage a consumer from seeking a residential mortgage loan secured by a consumer's principal dwelling from another mortgage originator." 73 The first two restrictions are designed to preclude fraudulent transactions, while the third is designed to stop the practice of steering customers into expensive, subprime loans when they would qualify for a conventional loan. These provisions again should curtail loans which have been prime candidates for default.

Part of the opposition to a requirement that the broker and the lender make a determination of the borrower's ability to repay has been based upon the argument that this is a subjective issue and that the subsequent events may push what had been a "good" loan into default. There is then the concern that a prior determination would be judged by hindsight.

To remedy this, the Act introduces a safe harbor for "qualified mortgages.", "I In general, a qualified mortgage is one that does not permit negative amortization or contain a balloon payment, is

\footnotetext{
${ }^{70}$ H.R. 4173, § 1403. (On August 16, 2010, the Federal Reserve Board amended its Truth in Lending Regulations, in effect, to provide mortgage brokers cannot be compensated by both the borrower and lender, and that they cannot be compensated by quoting a higher rates to the borrower in return for what in essence was a kickback from the lender. Available at http://www.federalreserve.gov/newsevents/press/bcreg/bcreg20100816d1.pdf).

${ }^{71}$ H.R. 4173, § 1401.

${ }^{72}$ H.R. 4173, § 1402.

${ }^{73} I d$.

74 A qualified mortgage is one:

"(i) for which the regular periodic payments for the loan may not -

(I) result in an increase of the principal balance or;

(II) except as provided in subparagraph (E), allow the consumer to defer repayment of principal;
}

(ii) except as provided in subparagraph (E), the terms of which do not result in a balloon payment where a 'balloon payment' is a scheduled payment that is more than twice as large as the average of earlier scheduled payments; 
extended upon verified documentation of the borrower's ability to repay based upon a fully amortizing payment schedule and takes into account forthcoming regulations relating to debt to income or other ratios, where the fees do not exceed $3 \%$, and the term of the loan does not exceed 30 years.

If the mortgage is a qualified mortgage, the lender and any assignee may assume that the determination of "ability to pay" has been met. ${ }^{75}$ In addition, if a qualified loan is securitized, the retention requirements of Subtitle D of Title IX are waived for the originator and the securitizer. ${ }^{76}$ This is discussed later.

From a liability perspective, the Financial Reform Act provides for actual damages or up to three times the compensation accruing to the mortgage originator in connection with the loan, together with costs and a reasonable attorney fee, when there has been a violation of these provisions. ${ }^{77}$ In addition, in foreclosure proceedings, the customer can assert violation by originator as a defense or set-off. ${ }^{78}$

The foregoing discussion is qualified by the fact that many of the requirements are subject to or are to be implemented by regulations to be promulgated by the Federal Reserve Board or other administrative bodies. Thus, it is not until these regulations are promulgated that a determination can be made of the effectiveness of some aspects of the legislation.

The creation of the new Consumer Financial Protection Bureau should also mitigate abusive mortgage lending practices. ${ }^{79}$ The Bureau may make investigations ${ }^{80}$ and conduct hearings, ${ }^{81}$ issue

(iii) for which the income and financial resources relied upon to qualify the obligors on the loan are verified and documented; (iv) in the case of a fixed rate loan, for which the underwriting process is based on a payment schedule that fully amortizes the loan over the loan term and takes into account all applicable taxes, insurance, and assessments;

(v) in the case of an adjustable rate loan, for which the underwriting is based on the maximum rate permitted under the loan during the first 5 years, and a payment schedule that fully amortizes the loan over the loan term and takes into account all applicable taxes insurance and assessments;

(vi) that complies with any guidelines or regulations established by the Board relating to ratios of total monthly debt to monthly income or alternative measures of ability to pay regular expenses after payment of total monthly debt, taking into account the income levels of the borrower and such other factors as the Board may determine relevant and consistent with the purposes described in paragraph $(3)(\mathrm{B})(\mathrm{i})$;

(vii) for which the total points and fees (as defined in subparagraph $(\mathrm{C})$ ) payable in connection with the loan do not exceed 3 percent of the total loan amount;

(viii) for which the term of the loan does not exceed 30 years, except as such term may be extended under paragraph (3), such as in high-cost areas; and

(ix) in the case of a reverse mortgage (except for the purposes of subsection (a) of section 129C, to the extent that such mortgages are exempt altogether from those requirement(s), a reverse mortgage which meets the standards for a qualified mortgage, as set by the Board in rules that are consistent with the purposes of this subsection.

H.R. 4173, § 1412 (adding $§ 129 C(b)(2)$ to the Truth in Lending Act.)

${ }^{75}$ H.R. 4173, $§ 1412$ (adding $§ 129 C(b)(1)$ to the Truth in Lending Act.)

${ }^{76}$ H.R. 4173, § 941(b).

${ }^{77}$ H.R. 4173, § 1404.

${ }^{78}$ H.R. 4173, § 1413.

${ }^{79}$ Title X, the "Consumer Financial Protection Act of 2010," creates a new "Bureau of Consumer Financial Protection" (the "Bureau") as an independent Bureau within the Federal Reserve System. See H.R. $4173 \S 1011$. 
cease and desist orders, and initiate litigation to prevent unfair, deceptive or abusive practices. ${ }^{82}$ It can also prescribe rules identifying unfair, deceptive or abusive practices. However the Act stringently defines unfairness as that which is likely to cause substantial, unavoidable injury to consumers that is not outweighed by countervailing benefits or competition, and defines abusive as that which materially interferes with consumers understanding or takes unreasonable advantage of a lack of consumer understanding, or the inability of the consumer to protect himself. ${ }^{83}$ In view of the tendency of federal courts to protect business over individuals, under the foregoing standards, the Bureau's rules could face tough sledding in federal court. ${ }^{84}$

In view of the foregoing, the Financial Reform Act is a reasoned and practical response to many of the abuses involving the customer, the broker and the lender that led to the subprime crisis. But the subprime debacle could not have occurred without the instrumentality of the investment bankers and others who facilitated the ability of lenders to get the loans off the books by securitizing them. While the Act responds to some of the actions of these actors, many incentives towards taking excessive risks remain and the "too big to fail" scenario may not be foreclosed for the future. These issues are addressed below.

\section{B. The Securitization Players: Investment Bankers and Credit Rating Agencies}

The subprime lenders would not have made the riskiest of loans if they were not able to sell them into the securitization market. Once a loan was sold, the lender could care less if the borrower could repay, since the lender had made its profit and no longer had "any skin in the game."

Subprime loans generally were sold either to Fannie Mae or Freddie Mac, sometimes referred to as government sponsored entities ("GSEs") or to investment banks that created what are sometimes known as private label securities ("PLSs"). However, investors would not have purchased these exotic securities unless the credit rating agencies, particularly Moody's, Standard \& Poor's, and Fitch, provided their stamp of approval, frequently in the form of a AAA rating.

The roles of the GSEs and investment banks, and the credit rating agencies, and the incentives that drove them, are analyzed below.

1. Fannie Mae, Freddie Mac, and the Investment Banks

\footnotetext{
${ }^{80}$ H.R. 4173, § 1052.

${ }^{81}$ H.R. 4173, $§ 1053$.

${ }^{82}$ H.R. 4173, $\S 1053-1055$.

${ }^{83}$ H.R. 4173, § 1031.

${ }^{84}$ See generally Charles W. Murdock, "Corporate Corruption and the Complicity of Congress and the Supreme Court- the Tortuous Path from Central Bank to Stoneridge Investment Partners,” 6 Berk. Bus. L.J. 131 (2009).
} 
There is no doubt that Fannie Mae and Freddie Mac, the dominant government sponsored entities ("GSEs"), committed serious errors of judgment and engaged in questionable underwriting practices in the 2004-2007 period, and that risky lending and securitization practices during this period were significant drivers of the subprime crisis. ${ }^{85}$ The American Enterprise Institute, a conservative think tank, however, laid the blame for the subprime crisis solely on the shoulders of Fannie Mae and Freddie Mac. In a position paper written when Congress was considering the subprime bailout, the authors of the paper stated:

This Outlook tells the disheartening story of how the GSEs [Fannie Mae and Freddie Mac] sold out the taxpayers by taking huge risks on substandard mortgages, primarily to retain congressional support for the weak regulation and special benefits that fueled their high profits and profligate executive compensation. As if that were not enough, in the process, the GSEs' operations promoted a risky subprime mortgage binge in the United States that has caused a worldwide financial crisis. ${ }^{86}$

Unfortunately, focusing solely upon the GSE's looks only at a small part of the picture. It fails to recognize that the investment banks were also a significant cause of the subprime crisis. In fact, a case can be made that the investment banks, by financing "non-banks, ${ }^{87}$ by buying and selling derivatives, and through their underwriting of private-label securities ("PLS"), were the predominant cause of the crisis.

\section{a. The Increasing Role of the Investment Banks}

Mortgage-backed securities ("MBS") increased from \$3.161 trillion in 2000 to $\$ 4.547$ trillion in 2003, a 44\% increase. ${ }^{88}$ However, from 2004 to 2007, mortgage backed securities increased from $\$ 4.835$ trillion to $\$ 7.417$ trillion, an increase of over $\$ 2.5$ trillion, or 53\%. Overall, mortgage-backed securities increased over $\$ 4.25$ trillion, or $135 \%$, from 2000 to $2007 .{ }^{89}$

Consider now the GSEs: Fannie Mae and Freddie Mac issued \$1.879 trillion in 2000, about 60\% of the total of mortgage-backed securities. This increased to $\$ 3.014$ trillion in 2003 , or about $66 \%$ of the total. But while the volume of mortgage-backed securities issued by these two GSEs grew steadily from

\footnotetext{
${ }^{85}$ Fannie Mae and Freddie Mac: What Happened and Where Do We Go from Here? Hearing Before Comm. On Oversight and Gov't Reform, U.S. House Of Representatives, Dec. 9, 2008 (testimony of Thomas H. Stanton).

${ }^{86}$ Peter J. Wallison \& Charles W. Calomiris, The Last Trillion-Dollar Commitment: The Destruction of Fannie Mae and Freddie Mac, America Enterprise Institute, Sept. 30, 2008, at 1, available at http://www.aei.org/publications/pubID.28704/pub_detail.asp.

${ }^{87}$ A mortgage bank which does not accept deposits is sometimes referred to as a "non-bank," and is not regulated the same as a bank that accepts deposits.

${ }^{88}$ Federal Reserve Board, 1.54 Mortgage Debt Outstanding, Statistical Supplement to the Federal Reserve Bulletin, Dec. 2004, at line 55, available at http://www.federalreserve.gov/pubs/supplement/2004/12/table1_54.htm.
}

${ }^{89}$ Board of Governors of the Federal Reserve System, Mortgage Debt Outstanding (1.54), June 2009, at line 55, available at http://www.federalreserve.gov/econresdata/releases/mortoutstand/current.htm. 
$\$ 3.09$ trillion in 2004 to $\$ 4.015$ trillion in 2007, the impact of these GSEs dropped from $64 \%$ to $54 \%$, ${ }^{90}$ since the private investment banks had now become a significant, if not dominant, participant in this market.

Then consider the private-label securities issued by the investment banks: From 2000 to 2003, the investment banks were minor players. Private-label securities group from \$0.667 trillion in 2000 to $\$ 1.058$ trillion in 2003. But from 2004 to 2007, private-label securities grew from \$1.291 trillion \$2.953 trillion, an increase of almost 130\%. From 2000 to 2007 private-label securities grew by an astounding $343 \% .^{91}$

From a relative perspective, between 2000 and 2003, private-label securities as a percentage of the mortgage-backed securities increased modestly from $21 \%$ to $23 \%$. But from 2004 to 2007, the percentage of private-label securities increased from $25 \%$ to $40 \%$. However, even though the investment bankers were no longer minor players, they still were not equal to the GSEs in volume or percentage. Why then were they so significant in causing the crisis?

There are three areas of culpability for the investment banks: (i) the risky nature of the loans they securitized, (ii) their financing of the subprime lenders, particularly the so-called "non-banks," and (iii) their sponsoring of derivatives. The first two are addressed below; a third is considered separately in a later section.

\section{b. The Risky Nature of Loans Securitized by Investment Banks}

The complicity of the investment bankers in the subprime meltdown is a function, not just of the volume of subprime loan that they securitized, but also the quality of such loans. A study by Fannie Mae on the comparative riskiness of Fannie Mae versus private-label Alt A loans is set forth in the table below: ${ }^{92}$

\footnotetext{
${ }^{90}$ Federal Reserve Board, 1.54 Mortgage Debt Outstanding, Statistical Supplement to the Federal Reserve Bulletin, Dec. 2004, at line 70, available at http://www.federalreserve.gov/pubs/supplement/2004/12/table1_54.htm.

${ }^{91}$ Board of Governors of the Federal Reserve System, Mortgage Debt Outstanding (1.54), June 2009, at line 70, available at http://www.federalreserve.gov/econresdata/releases/mortoutstand/current.htm.
}

\footnotetext{
${ }^{92}$ Fannie Mae, 2009 Second Quarter Credit Supplement, Aug. 6, 2009, at 12, available at http://www.fanniemae.com/ir/pdf/sec/2009/q2credit_summary.pdf.
} 


\begin{tabular}{|c|c|c|}
\hline \multicolumn{3}{|c|}{ Fannie Mae Alt-A Versus Private-Label Security Conforming Alt-A } \\
\hline & $\begin{array}{l}\text { Fannle Mae Alt-A } \\
\text { Outstanding Alt-A loans } \\
\text { In Fannle Mae's SIngle- } \\
\text { Famlly Guaranty Book of } \\
\text { Business as of May } 2009\end{array}$ & $\begin{array}{l}\text { Prlvate-Label Ait-A } \\
\text { Outatanding loans } \\
\text { backing non-agency } \\
\text { Conforming Alt-A MBS } \\
\text { as of May 2009 }\end{array}$ \\
\hline FICO & 718 & 710 \\
\hline Original Loan-to-Value Ratio & $73 \%$ & $75 \%$ \\
\hline $\begin{array}{l}\text { Combined Loan-to-Value } \\
\text { Ratio at Origination }{ }^{60}\end{array}$ & $77 \%$ & $81 \%$ \\
\hline $\begin{array}{l}\text { Geography } \\
\text { Calfornla } \\
\text { Florida }\end{array}$ & $\begin{array}{l}22 \% \\
11 \%\end{array}$ & $\begin{array}{l}27 \% \\
13 \%\end{array}$ \\
\hline $\begin{array}{l}\text { Product Type } \\
\text { Fured Rate } \\
\text { Adjustable-Rate } \\
\text { interest-Only } \\
\text { Negative-Amortizing }\end{array}$ & $\begin{array}{c}72 \% \\
28 \% \\
20 \% \\
3 \%\end{array}$ & $\begin{array}{l}50 \% \\
50 \% \\
25 \% \\
20 \%\end{array}$ \\
\hline Investor & $18 \%$ & $21 \%$ \\
\hline
\end{tabular}

Only $28 \%$ of the Fannie Mae loans were adjustable rate loans, whereas $50 \%$ of the PLS loans were. As discussed earlier, adjustable rate loans were prime candidates for default when their "teaser" rates reset and the mortgage payments doubled. In addition, only 3\% of the Fannie Mae loans were "pic-a-pay," or negative amortization loans, whereas $20 \%$ of the PLS loans were. If a borrower cannot even pay the interest at the outset of the loan, when the loan resets to an amortization schedule at a higher interest rate, the likelihood of default obviously increases dramatically.

The anticipated higher default rate for the private-label securities underwritten by the investment banks is confirmed by the graph below: $:^{93}$

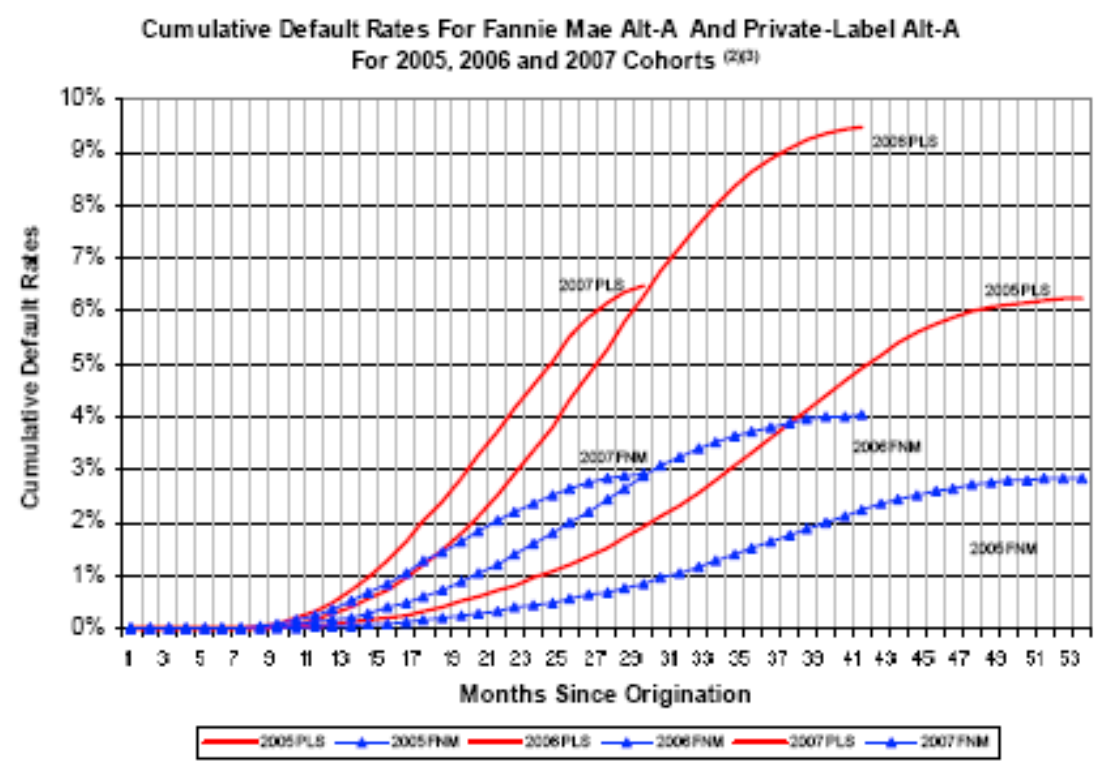

${ }^{93} I d$. 
For each cohort of loans -- 2005, 2006, and 2007 -- the default rate for the private label Alt A loans is more than twice that of the Fannie Mae Alt A loans.

The risky loans that the investment banks were willing to securitize also had an impact on the practices of the government sponsored entities. In 2003, Fannie Mae had lost 56\% of its loan reselling business to investment bankers and other competitors. Accordingly, the next year, Daniel Mudd, the CEO of Fannie Mae, met with Angelo Mozilo, the head of Countrywide Financial, which sold more loans to Fannie Mae than any one else. ${ }^{94}$ Mozilo threatened to upend their partnership unless Fannie started buying Countrywide's riskier loans. Since the investment banks were moving heavily into the securitization business, this was no idle threat. According to anonymous sources, Mozillo, told Mudd that "you're becoming irrelevant," and added that, if Fannie Mae didn't take the loans that Mozillo was pushing, "you'll find you can lose much more." 95

\section{c. Investment Bank Financing of Subprime Lenders}

Besides securitizing loans, the investment banks, together with the large commercial banks, were a major source of financing for the subprime lenders. In addition, the investment banks also had subprime lending subsidiaries. Bear Stearns owned and operated EMC Mortgage, while Merrill Lynch bought First Franklin, a non-bank lender that used only independent loan brokers who were paid on commission. ${ }^{96}$ BNC Mortgage Inc. was part of Lehman Brothers. ${ }^{97}$ However, more significant was the fact that the investment and commercial banks funded the operations of the non-bank subprime lenders. For example, the 10-Q report for New Century Financial Corp., for the quarterly period ended June 30, 2006, disclosed:

We have credit facilities with Bank of America, N.A., Barclays Bank PLC, Bear Stearns Mortgage Capital Corporation, Citigroup Global Markets Realty Corp., Credit Suisse First Boston Mortgage Capital LLC, Deutsche Bank Securities, Inc., IXIS Real Estate Capital Inc. (formerly known as CDC Mortgage Capital Inc.), Morgan Stanley Mortgage Capital Inc., UBS Real Estate Securities Inc., Goldman Sachs Mortgage Company, State Street Bank and Trust Company and Guaranty Bank, and we also have an asset-backed commercial paper facility. We use these facilities to finance the actual funding of our loan originations and purchases and to aggregate pools of mortgage loans pending sale through securitizations or whole loan sales. We

\footnotetext{
${ }^{94}$ See Charles Duhigg, The Reckonoing: Pressured to Take More Risk, Fannie Reached Tipping Point, N.Y. TIMES, Oct. 5, 2008, available at http://www.nytimes.com/2008/10/05/business/05fannie.html?pagewanted=print

${ }^{95}$ Id. This conversation did not dissuade Fannie Mae from aggressively pursuing Countrywide's business and from buying risky loans. See Gretchen Morgenson, Housing Policy's Third Rail, N.Y. TIMES, Aug. 8, 2010, 2008, available at http://www.nytimes.com/2010/08/08/business/08gret.html

${ }^{96}$ Judge Thomas L. Perkins, The Origins of the Subprime Mortgage Crisis, ATTY's TITLE GUARANTY FUnD, INC. TRUSTED ADVISER, Oct. 2008, available at http://www.atgf.com/AllAttorneys/ATGNewslettersArchive/TheTrustedAdviser/tabid/459/Default.aspx.
}

\footnotetext{
${ }^{97}$ The Center for Public Integrity, supra note 64, at 15. In addition, some of the largest commercial banks also had the
} subprime lending units, including Wells Fargo, J.P. Morgan Chase, Citigroup, and HSBC Holdings. Id. 
typically sell all of our mortgage loans within one to three months of their funding and pay down the credit facilities with the proceeds. ${ }^{98}$

From a dollar standpoint, there was a $\$ 3$ billion line of credit from Bank of America, \$1 billion from Barclays, $\$ 800$ million from Bear Stearns, $\$ 1.5$ billion from Credit Suisse First Boston, $\$ 3$ billion from Morgan Stanley, and \$450 million from Goldman Sachs, as well as additional billions from other major commercial banks. ${ }^{99}$ The financial statements of New Century for this period showed $\$ 9,303,086,000$ of mortgage loans held for sale and $\$ 8,786,300,000$ of credit facilities on such loans. ${ }^{100}$ In other words, the investment and commercial banks were providing almost $100 \%$ financing.

d. The Financial Incentives for Investment Banks

What drove the investment banks to fund the subprime lenders and securitize their loans? It is the same incentives that drove the subprime lenders: revenues translating to earnings, leading to stock appreciation and executive compensation. The stock performance of Merrill Lynch from 2003 to 2008 is not unlike that of Countrywide: ${ }^{101}$

\footnotetext{
${ }^{98}$ New Century Financial Corp., 10-Q report for quarter ended June 30, 2006, at 67, available at http://www.sec.gov/Archives/edgar/data/1287286/000089256906000974/a22754e10vq.htm

${ }^{99} I d$. at 67-69.

${ }^{100}$ Id. at 5.

${ }^{101}$ Since Merrill Lynch is no longer publicly traded, this graph was developed from data available from Thomson Reuters "Datastream." The code for Merrill Lynch is 922060.Cf. the stock price graph for Countrywide at note 45 supra.
} 


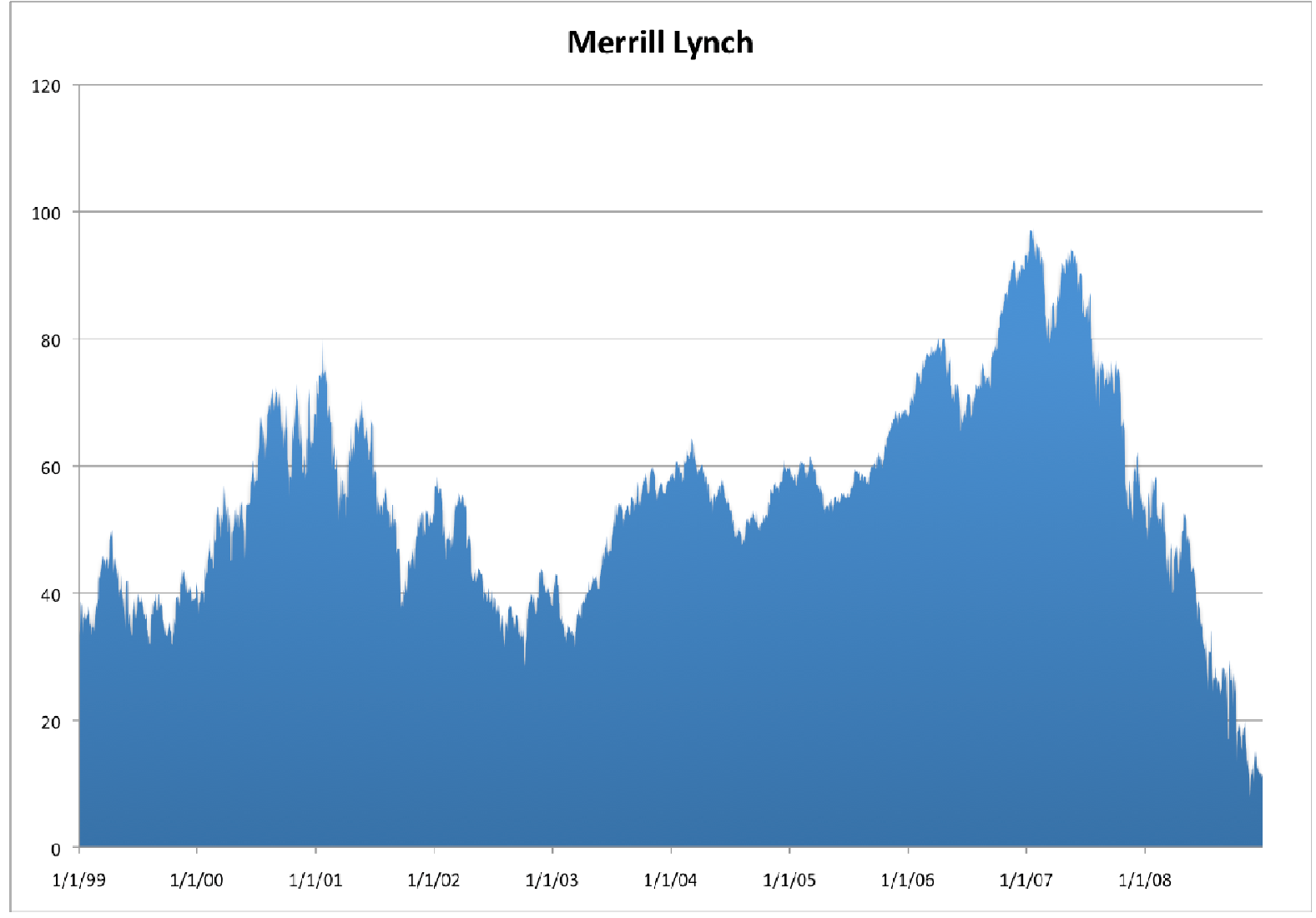

Merrill Lynch stock had dropped into the 30s around the start of 2003. After aggressively getting into the subprime mortgage game, the stock rose into the 90s in 2007 and then dropped precipitously when the subprime crisis unfolded. While the Dow Jones industrial average increased about $50 \%$ in that period, ${ }^{102}$ this increase paled in comparison to Merrill Lynch which increased about $200 \%$. There is a similar pattern with Wall Street bonuses as disclosed by the comptroller of New York State, ${ }^{103}$ except that bonuses have not yet dropped precipitously:

\footnotetext{
${ }^{102}$ See Yahoo Finance, Dow Jones Industrial Average, http://finance.yahoo.com/echarts?s=\%5EDJI\#chart10:symbol=^dji;range=my;indicator=volume; charttype=line; crosshair=on; ohlcvalues $=0 ; \operatorname{logscale}=$ on; source $=$ undefined (last visited Oct. 9, 2009).

${ }^{103}$ See New York City Securities Industry Bonuses, The Office of the State Deputy Comptroller, Jan. 28, 2009, http://www.osc.state.ny.us/press/releases/jan08/bonus.pdf (last visited Oct. 9, 2009).
} 


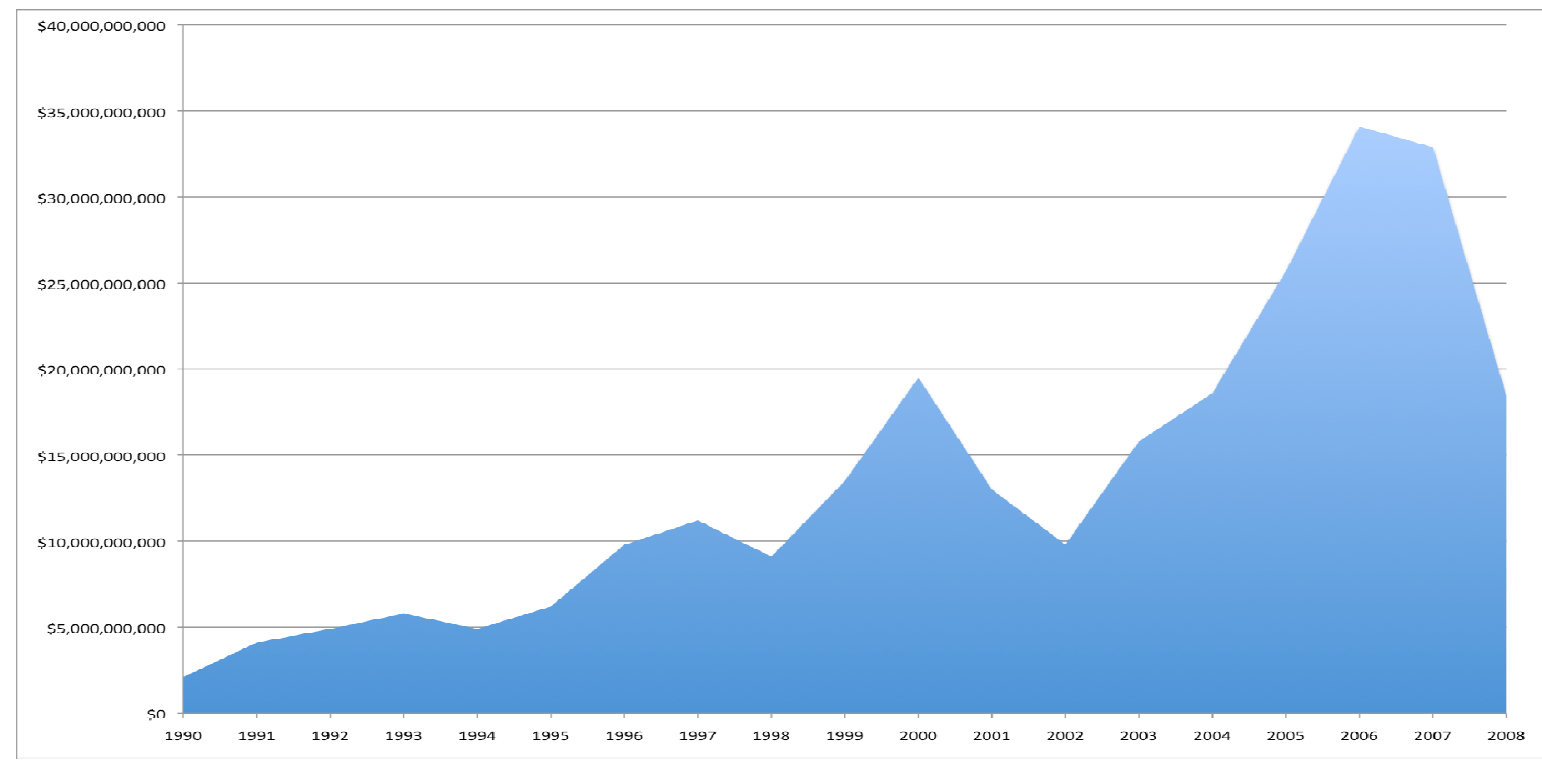

The average Wall Street bonus increased from $\$ 74,140$ in $\$ 2001$ to $\$ 99,930$ in 2003 . However, between 2003 and 2006, it almost doubled to $\$ 190,600 .{ }^{104}$ Funding the subprime lenders and packaging subprime mortgages into securities paid off handsomely during those years.

The final guidance by the federal banking regulators recognized that flawed incentive compensation practices in the banking industry was one of the factors that led to the financial crisis. The report opined:

Incentive compensation practices in the financial industry were one of many factors contributing to the financial crisis that began in mid-2007. Banking organizations too often rewarded employees for increasing the organization's revenue or short-term profit without adequate recognition of the risks the employees' activities posed to the organization1. These practices exacerbated the risks and losses at a number of banking organizations and resulted in the misalignment of the interests of employees with the long-term well-being and safety and soundness of their organizations. ${ }^{105}$

The guidance recognized that it was important to align management incentives with the interests of shareholders since it may protect the safety of the organization, but this is not enough to address safetyand-soundness concerns. ${ }^{106}$

\footnotetext{
${ }^{104} I d$.

${ }^{105}$ Department of Treasury, GuIDANCE ON SOUND InCENTIVE COMPENSATION POLICIES, at 23, June 21, 2010, available at http://www.ots.treas.gov/_files/25354.pdf.
}

${ }^{106} I d$. 
In the previous section, it was asserted that stock options do not align the interests of management with those of the shareholders. ${ }^{107}$ The New York Times recently did an analysis of how shareholders and management would fare after Merrill Lynch's "new" incentive plan was introduced in 2006. ${ }^{108}$ The article stated that the incentive program "did not keep workers from taking risks that nearly sank a brokerage giant." But many of the major risks were taken in the period 2004 to 2006, before the plan went into effect, so the plan cannot be blamed for the risks that the employees took. However, it does demonstrate that the incentive program did not align the interests of managers and shareholders. The study compared a $\$ 2$ million investment by private investors with a $\$ 2$ million investment by company management. The executives would have realized a $\$ 570,000$ gain on their investment, or an annualized return of $9 \%$, whereas the private investors would have lost $\$ 1.55$ million, or $-45 \%$ return on their investment. The top six executives would have lost money because they had a less favorable match of company contributions, but they still would have lost less than the private investors.

\section{The Rating Agencies}

Probably the most reprehensible players in the subprime crisis have been the credit rating agencies. It is clear that the goal of mortgage brokers, mortgage lenders and investment banks is to make money for the benefit of their shareholders. With respect to the credit rating agencies, on the other hand, while they are in business, their business is involved with the public trust. They are seen, or rather had been seen, as institutions upon whom investors could rely for impartial judgment. Investors around the world relied upon their analysis. Mortgage-backed securities and collateralized debt obligations are complex instruments, ${ }^{109}$ which few investors would have the time or expertise to analyze. Standard and Poor's said that "Lehman and AIG are included in 2634 tranches of 1889 synthetic CDO's." ${ }^{110}$ The Securities and Exchange Commission has observed:

Some investors use the credit ratings to assess the risk of the debt instruments. In part, this may be due to the large number of debt instruments in the market and their complexity. Other investors use credit ratings to satisfy client investment mandates regarding the types of securities they can invest in or to satisfy regulatory requirements based on certain levels of credit ratings, or a combination of these conditions. Moreover, investors typically only have looked to ratings

\footnotetext{
${ }^{107}$ See supra Part II.A.3.

${ }^{108}$ See Louise Story, In Merrill's Failed Plan, Lessons for Pays Czar, N.Y. TIMES, Oct. 8, 2009, available at http://www.nytimes.com/2009/10/08/business/08pay.html?_r=1\&th\&emc=th (the articles summarize the plan as follows: “Tie executives' compensation to their company's stock price. Withhold big paydays for years. Claw back bonuses if things go wrong. And force risk-loving traders to gamble with their own money, not just their company's.")

${ }^{109}$ See, e.g., the 317 page Prospectus Supplement dated Dec. 15, 2005 (to Prospectus dated Apr. 22, 2005), \$1,793,630,000 (Approximate) Asset-Backed Pass-Through Certificates, Series 2005-R11, Ameriquest Mortgage Securities Inc., Depositor, available at http://www.secinfo.com/dr66r.z2F9.htm\#gmw; see also http://www.sec.gov/Archives/edgar/data/1257102/000088237705003567/d410363_424b3-file2.htm (last visited Oct. 9, 2009).

${ }^{110}$ S\&P Likely to Cut Derivative Deals on Lehman, AIG, REUTERS, Sept. 16, 2008, available at http://www.reuters.com/article/rbssFinancialServicesAndRealEstateNews/idUSN1625304920080916.
} 
issued by Fitch, Moody's, and S\&P, which causes the arrangers of the subprime RMBS and CDOs to use these three NRSROs to obtain credit ratings for the tranche securities they brought to market. ${ }^{111}$

As previously discussed, the period 2004 to 2007 was a critical one in terms of the deterioration of quality of the mortgages that were securitized. ${ }^{112}$ In 2004, Moody's and Standard \& Poor's eased their standards under pressure from Wall Street to enable more securities to be rated AAA. They changed their rating models to accommodate more concentration in one type of asset and utilize a hypothetical investment pool. The overall effect was to create more AAA (the supposedly safest type) securities. ${ }^{113}$ Thereafter, one study found that the value of AAA-rated mortgage-backed securities (as measured by the corresponding credit default swaps prices) had fallen by 70 percent between January 2007 and December 2008. ${ }^{114}$ Accordingly to another report, by August 2008, Moody's had downgraded $90 \%$ of all asset-backed CDO investments issued in 2006 and 2007, and Standard \& Poor's had downgraded $84 \%$ of the CDO tranches it rated. ${ }^{115}$ Moreover, they had downgraded $85 \%$ and $76 \%$ respectively of the AAA's they had rated.

What happened? Basically the rating agencies were bought off by the investment bankers. At one time, the creditor rating agencies charged a subscription fee to subscribers to cover their rating activity. ${ }^{116}$ That has changed: the current practice is that the company or issue being rated pays the fee. Thus, there is an inherent conflict of interest. Standard \& Poor's, for example, claimed that such a conflict was not a concern since it rated 37,000 issues. ${ }^{117}$ However, with respect to structured financial products such as the securitized mortgages, the rating agencies could charge almost three times as much as they charged for rating corporate bonds. ${ }^{118}$ This created a huge incentive "to get the business." While

${ }^{111}$ Proposed Rules for Nationally Recognized Statistical Rating Organization, Exchange Act Release No. 34-57967 [File No. S7-13-08] at 12-13 (June 16, 2008).

See supra Part II.

${ }^{113}$ See Elliot B. Smith, 'Race to the Bottom' At Moody's, S\&P Secured Subprime's Boom, Bust, BLOOMBERG, Sept. 25, 2008, available at http://www.bloomberg.com/apps/news?pid=20601109\&sid=ax3vfya_Vtdo\&refer=home.

114 See Marco Pagano and Paolo Volpin, Credit Ratings Failures: Causes and Policy Options, (Feb. 9, 2009) (working paper, prepared for the CEPR conference on "Financial Regulation and Macroeconomic Stability: Key Issues for the G20," hosted by the British Treasury and the Bank of England on 31 January 2009), available at

http://www.italianacademy.columbia.edu/publications/working_papers/2008_2009/pagano_volpin_seminar_IA.pdf.

${ }^{115}$ See Market Pipeline, Bringing Down Wall Street As Ratings Let Loose Subprime Scourge, Sept. 25, 2008, available at http://marketpipeline.blogspot.com/2008/09/bringing-down-wall-street-as-ratings_25.html.

${ }^{116}$ See Standard \& Poor's Ratings Services Statement, Role and Function of Credit Rating Agencies in the U.S. Securities Markets, SEC public hearing, Nov. 15, 2002, available at http://www.sec.gov/news/extra/credrate/standardpoors.htm ("Since 1968, Standard \& Poor's has charged issuers for its credit rating services. The practice was implemented because of increasing costs related to credit ratings surveillance and the growing need for more ratings coverage. Prior to that, Standard \& Poor's provided its credit ratings services on the basis of subscription fees, which were not adequate to offset the increased costs of maintaining a high level of quality in this business.")

${ }^{117} I d$.

118 See Market Pipeline, Bringing down Wall Street As Ratings Let Loose Subprime Scourge, Sept. 25, 2008, available at http://marketpipeline.blogspot.com/2008/09/bringing-down-wall-street-as-ratings_25.html. 
there are those who advocate going back to a subscription fee, ${ }^{119}$ the rating agencies disagree. ${ }^{120}$ In an electronic world, the agencies worry about the problem of free riding.

But the fees paid for rating services were not the only conflicts of interest that infected the rating process. Former SEC Chairman Cox has observed that "structured products were specifically designed for each tranche to achieve a particular credit rating — and the ratings agencies then made a lucrative business of consulting with issuers on exactly how to go about getting those ratings. Selling consulting services to entities that purchased ratings became a triple-A conflict of interest." ${ }^{\text {"121 }}$ Fortunately, the SEC has adopted a new rule prohibiting this activity. ${ }^{122}$

Of the three rating agencies, Moody's is the only freestanding, publicly traded agency. ${ }^{123}$ Once again, it is instructive to look at the stock price movement during the time of the subprime crisis. From 2003 to 2007, the price of Moody's advanced from \$20 a share to about \$70 a share, or increase of about $250 \%$. See chart below. ${ }^{124}$ The process repeats itself: more business means more income means stock appreciation. There is nothing wrong with this process so long as the increased business is legitimate.

119 See Pagano \& Volpin, supra note 114.

${ }^{120}$ Hearing Before Comm. On Oversight and Gov't Reform, U.S. House Of Representatives, Oct. 22, 2008 , at 8 (testimony of Raymond W. McDaniel, Chairman and Chief Executive Officer, Moody's Corporation) available at http://oversight.house.gov/documents/20081022125014.pdf

${ }^{121}$ See Christopher Cox, Statement at Open Meeting on Rules for Credit Rating Agencies, June 11, 2008, available at http://www.sec.gov/news/speech/2008/spch061108cc.htm.

${ }^{122}$ Rule 17g-5(c)(5), 17 C.F.R. §240, adopted 74 FR 6456 (Feb. 9, 2009).

${ }^{123}$ Moody's became an independent, publicly traded company as a result of a spinoff on Sept. 30, 2000. For a history of the various spinoffs by which Moody's became an independent company, see its 2002 10-K. report, Item 1: Business -Background, available at http://www.sec.gov/Archives/edgar/data/1059556/000095012303003112/y83456e10vk.htm

${ }^{124}$ See Yahoo Finance, Moody's Corp., http://finance.yahoo.com/echarts?s=MCO\#chart1:symbol=mco;range=my;indicator=volume; charttype=line; crosshair=on;ohl

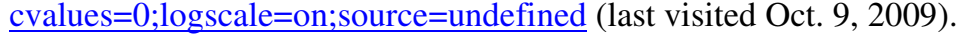




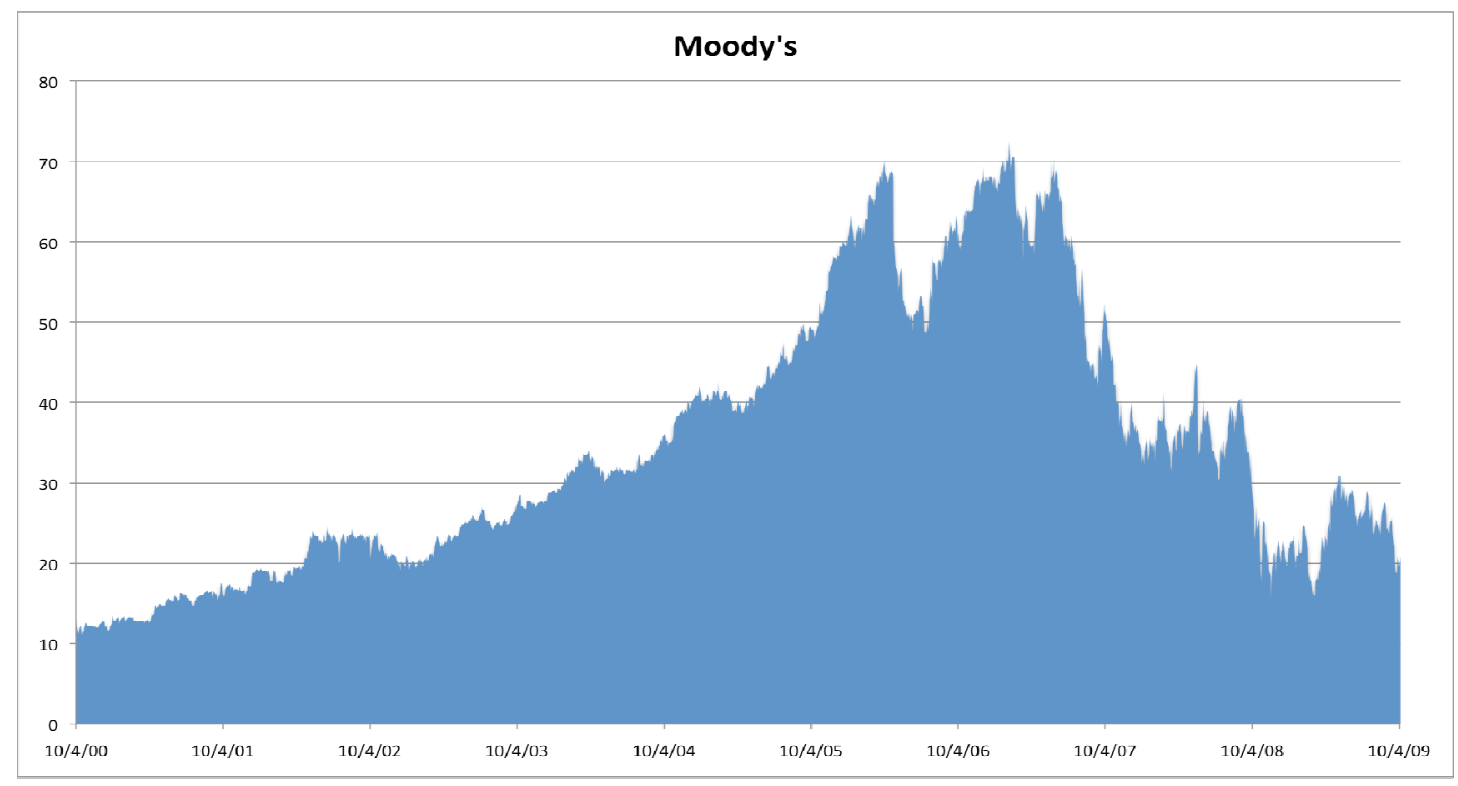

How do you change the mindset that "let's hope we are all wealthy and retired by the time this house of cards falters." 125 One way would be to go back to the practice that prevailed before 1970 and have the investor, rather than the issuer, pay the fee. However, the implementation process and costs for such a change over would be substantial; accordingly, a study presented to the British Treasury and Bank of England recommended that "issuers should pay an upfront fee irrespective of the rating issued (the so-called "Cuomo plan," named after NY Attorney General Andrew Cuomo) and credit shopping should be banned."126

Another possibility would be to subject the rating agencies to civil liability. Until the Financial Reform Act, rating agencies were insulated from liability under section 11 of the federal securities act. ${ }^{127}$ While the Financial Reform Act would reverse that, ${ }^{128}$ the rating agencies long contended that their ratings are opinions which are protected under the First Amendment as free speech. ${ }^{129}$

\footnotetext{
${ }^{125}$ SEC Staff Summary Report of Issues Identified in the Commission Staff's Examination of Select Credit Rating Agencies, (July 2008), available at http://www.sec.gov/news/studies/2008/craexamination070808.pdf (quoting December 2006 e-mail from an analyst).

${ }^{126}$ See Pagano \& Volpin, supra note 114, at 3.

${ }^{127}$ See 15 USC $\$ 77 \mathrm{k}$, Rule 436(g)(1), 17 CFR $\$ 230.436(\mathrm{~g})(1)$, provides that a rating which is assigned to a security "shall not be considered a part of the registration statement prepared or certified by a person within the meaning of sections 7 and 11 of the Act"

${ }^{128}$ See Chairman Paul E. Kanjorski, Opening Statement, Subcommittee on Capital Markets, Insurance, and GovernmentSponsored Enterprises, Hearing on Reforming Credit Rating Agencies, Sept. 30, 2009, available at http://www.house.gov/apps/list/hearing/financialsvcs_dem/09_09_30_cra_hearing_opening_statement.pdf, and Part III.B.4.

${ }^{129}$ See Standard \& Poor's Ratings Services Statement, supra, note 116 ("Today, credit rating agencies are free to develop and publish their credit rating opinions under strong First Amendment protections. Indeed, it is Standard \& Poor's key role as a publisher of credit ratings and financial information that has been the basis for judicial recognition of significant First Amendment protections afforded to Standard \& Poor's."). See also Frank Partnoy, How and Why Credit Rating Agencies Are Not Like Other Gatekeepers, http://papers.ssrn.com/sol3/papers.cfm?abstract_id=900257 (last visited Oct. 9, 2009).
} 
3. The Tepid Response of the Financial Reform Bill to the Investment Banks

While the provisions of the Financial Reform Act should curtail the creation of toxic mortgages in the future, whether it will curtail the taking of excessive risk in other circumstances is less clear. Management of both the mortgage banks and the investment banks were motivated to take what ultimately turned out to be excessive risk driven by the desire for short term profits with little apparent risk because the mortgages could be sold and securitized without recourse. While the toxic mortgages were rapidly turned over, as the crises unfolded, many of these banks were caught with toxic instruments still on their books.

Most of the major subprime lenders were "non-banks," that is, they did not accept deposits, but rather were funded by loans from the commercial and investment banks. After the repeal of the GlassSteagall act, ${ }^{130}$ commercial and investment banking activities often resided side by side in the same institution. Thus, the public's deposits were put at risk, leading to the charge that the banks took excessive risk with other people's money. Because of the size and interconnectedness of the major banks, they were deemed "too big to fail."

Putting derivatives to one side for the time being, there are five issues that true financial reform needed to address: (i) the lack of accountability by operating on a no-recourse basis or, as said in the trade, having no skin in the game; (ii) management incentive programs which encouraged excessive risk taking in the short run, without accountability should the bets turn sour in the long run; (iii) undercapitalization of the major banks such that, when the toxic assets on their books dropped in value, capital was depleted and the banks were legally, if not equitably, insolvent; (iv) proprietary trading, arguably with depositors' money, and (v) size and interconnectedness of such magnitude as to give rise to "too big to fail." Let us consider each and the response of the Financial Reform Act.

\section{a. "No Skin in the Game" Versus Risk Retention}

One reason mortgage banks and investment banks were so cavalier in creating and securitizing toxic mortgages is that they perceived they had no risk if the mortgage went into default since they would have sold off the risk by securitizing the mortgage. Thus the characterization: "no skin in the game."

Subtitle D of Title IX imposes credit risk retention obligations in certain circumstances. It coordinates with Title XIV, dealing with standards for mortgages, ${ }^{131}$ by eliminating risk retention requirements for qualified residential mortgages, ${ }^{132}$ and provides that the definition of qualified

\footnotetext{
${ }^{130}$ The Glass-Steagall act was adopted in 1933 to separate commercial and investment banking. It was repealed in 1999 by the Gramm Leach Bliley Act, which was lauded at the time as a further step in the deregulation of financial institutions. See Reem Heakal, What Was the Glass-Steagall Act?, available at http://www.investopedia.com/articles/03/071603.asp (the author's positive comments about the benefits of repeal were written prior to the current financial crisis).

${ }^{131}$ See supra $\S$ III. A. 4.

${ }^{132}$ H.R. 4173, § 941(b) (adding $§ 15 G(c)(1)(C)(i i i)$ to the 1934 Securities Exchange Act).
} 
mortgages under Title IX cannot be broader than the definition under Title XIV. ${ }^{133}$ For other assetbacked securities, regulations must establish a risk retention requirement of at least $5 \%,{ }^{134}$ unless the originator of the loan meets standards promulgated by regulation that indicates a low credit risk. In such circumstance, the risk retention can be less than $5 \%{ }^{135}$ The risk retention cannot be hedged. ${ }^{136}$

The forthcoming regulations must also allocate the retained risk between the originator of the loan and the securitizer who packages loans into securities ${ }^{137}$ and should establish asset classes and underwriting standards for different classes of assets, such as residential mortgages, commercial mortgages, commercial loans, auto loans and other types of assets. ${ }^{138}$

The 1934 Securities Exchange Act was also amended by the Financial Reform Act to remove the exemption from registration for certain real estate transactions ${ }^{139}$ and to enhance the disclosure obligations of the securitizer with respect to each tranche or class of security. Such disclosure should facilitate comparison of data across securities and, at a minimum, disclose risk retention data and appropriate data to enable investors to do due diligence. ${ }^{140}$ A securitizer is also required to disclosure repurchase requests across all the securitizer's trusts so that investors will be able to identify mortgage originators with weak or deficient underwriting standards. ${ }^{141}$ Finally, the securitizer is required to perform a due diligence review of the underlying assets and to disclose the nature of such review. ${ }^{142}$

All of the above is subject to implementation by rule making and the banking agencies and SEC can adopt "exemptions, exceptions, or adjustments" for classes of institutions or assets. ${ }^{143}$ Since Congress was heavily lobbied to induce risk retention in the legislation, we can expect the regulatory agencies also to be heavily lobbied to minimize the impact of the legislation through weak rules. ${ }^{144}$

${ }^{133}$ H.R. 4173, § 941(b)(adding §15G(e)(4)(C) to the 1934 Securities Exchange Act).

${ }^{134}$ H.R. 4173, § 941(b) (adding §15G(c)(1)(B)(i) to the 1934 Securities Exchange Act).

${ }^{135}$ H.R. 4173, § 941(b) (adding $§ 15 G(c)(1)(B)(i i)$ to the 1934 Securities Exchange Act).

${ }^{136}$ H.R. 4173, § 941(b) (adding §15G(c)(1)(A) to the 1934 Securities Exchange Act).

${ }^{137}$ H.R. 4173, § 941(b) (adding §15G(d) to the 1934 Securities Exchange Act).

${ }^{138}$ H.R. 4173, § 941(b) (adding §15G(c)(2) to the 1934 Securities Exchange Act).

${ }^{139}$ H.R. 4173, § 944(a) (deleting § 4(5) from the 1934 Securities Exchange Act).

${ }^{140}$ H.R. 4173, § 942(b) (adding §7(c) to the 1933 Securities Act).

${ }^{141}$ H.R. $4173, \S 943$.

${ }^{142}$ H.R. 4173, § 942(b) (adding §7(d) to the 1933 Securities Act).

${ }^{143}$ H.R. 4173, § 945 (adding §15G(e)(1) to the 1934 Securities Exchange Act).

${ }^{144}$ See Eric Lichtblau, Ex-Regulators Get Set to Lobby on New Financial Rules, N. Y. TIMES, July 27, 2010, available at http://www.nytimes.com/2010/07/28/business/28lobby.html?_r=1\&th\&emc=th. 
The efficacy of the above remains to be seen. The 5\% standard itself is not a substantial guarantee since it can be allocated between originator and securitizer, both of which, as discussed earlier, often receive fees in excess of 5\%. If the retention is allocated equally, the originator and the securitizer will each only have $2 \frac{1}{2} \%$ of the risk. In the long run, the obligation to do due diligence and to disclose the nature of such diligence may have a more positive impact.

\section{b. The "Tired" Solution to Executive Risk Taking}

During 2004-2007, when the bulk of the toxic mortgages were originated and securitized, this article has already demonstrated that the earnings and stock prices of the subprime lenders and investment bankers skyrocketed. So did Wall Street bonuses and the compensation of financial executives. In effect, these persons were being highly rewarded for leading the nation into a financial crisis.

The article has also pointed out that, contrary to conventional wisdom, stock options do not align management incentive to those of shareholders. Shareholders have a sunk investment that they can lose in the long term. Stock options provide management with the opportunity to hype the price of stock without making an investment, then to exercise the option and quickly get out if storm clouds appear on the horizon. While Mozilla of Countrywide was charged with insider trading, federal courts have been reluctant to crack down on insider trading, particularly as it reflects on scienter. ${ }^{145}$

The Act's approach to management accountability is basically the same tired and ineffective approach that Congress and the SEC have employed for years without success: disclosure and supposedly independent compensation committees. With respect to compensation committees, the Act does give the committee the authority to engage independent legal counsel and other advisers. ${ }^{146}$ This could be significant if the compensation committee is inclined to exercise independent judgment which, unfortunately, many are not. ${ }^{147}$

\footnotetext{
${ }^{145}$ Charles W. Murdock, "Corporate Corruption and the Complicity of Congress and the Supreme Court- the Tortuous Path from Central Bank to Stoneridge Investment Partners, ” 6 Berk. Bus. L.J. 131, 177-182 (2009)(analyzing the fallacious approach federal courts have taken in determining that stock under options is included in the denominator in determining the percentage of holdings that an executive has sold.)

${ }^{146}$ H.R. 4173, $§ 952(a)$ (adding $§ 10 C(d)$ to the 1934 Securities Exchange Act).

147 The Commission on Public Trust and Private Enterprise has stated:

In the area of executive compensation, the Commission shares the public's anger over excessive compensation, especially to executives of failed or failing companies who may have garnered substantial compensation even as their companies and the retirement savings of their employees have collapsed. The additional collapse of the dot.com market and the abrupt halt of the raging bull market of the 1990s (with its unsustainable growth and unrealistic price/earnings ratios) have also contributed to an unprecedented loss of confidence in the stock market and in corporate America. Commission on Public Trust and Private Enterprise Executive Summary, at 4 (2003), available at http://www.conference-board.org/pdf_free/SR-03-04-ES.pdf.
}

The Commission stated that its recommendations "are based on perceptions of lax board and compensation committee oversight, skewed relationships between consultants and compensation committees, failure to effectively tie compensation to long term corporate growth and success, and excessive use of fixed-price stock options whose value related more to short term stock price gains than to long-term performance goals." Id. at 6 . It then asserted that there was a delinking of 
One positive addition to the disclosure requirements is that disclosures are now required to provide information showing "the relationship between executive compensation actually paid and that the financial performance of the issuer." 148 This is an effort to introduce some rationality and accountability into executive compensation. The Act also requires disclosure of the ratio of the CEOs compensation to that of the median pay of other employees. ${ }^{149}$ This may produce some shocking results. In 2001 Business Week reported that "[o]n average, CEOs at 365 of the largest publicly traded U.S. companies earned \$13.1 million last year, or 531 times what the typical hourly employee took home." 150 In the past decade, the spread is even greater as CEO compensation has risen and employee compensation has been essentially flat.

The Financial Reform Act does require financial institutions to disclose "the structure of all incentive-based compensation arrangements" (but not the actual compensation of particular individuals) and requires Federal regulators to prescribe regulations or guidelines that prohibit an incentive provision that "encourages inappropriate risks" through "excessive compensation," or that could lead to "material financial loss." 151 Unfortunately, these are the same regulators who did not limit Wall Street compensation before bailing out Wall Street. There is also a new requirement that companies disclose whether any employee or director is permitted to purchase financial instruments enabling the person to hedge the value of the company stock in the events of a decline in value. ${ }^{152}$ This should make executives more cautious in undertaking risk since they would not be able to hedge a drop in stock price. Note, however, that hedging is not prohibited; rather it only must be disclosed.

compensation and performance and that excessive use of stock options, in which executive had little downside risk, encouraged excessive risk-taking:

The Commission believes that in the executive compensation area there has been a "perfect storm" - a confluence of events that created an environment ripe for abuse. The excessive use of stock options-especially fixed-price options-was encouraged by the fact that they did not result in a charge to earnings while providing substantial tax deductions. In the unprecedented bull market of the 1990s, the substantial use of stock options and other equitybased incentives resulted in an enormous incentive to manage companies for short-term stock price gains and led to massive unanticipated gains in options unrelated to management's operating performance. In sum, executive compensation has become too "de-linked" from long-term performance goals in many corporations. There is an imbalance between unprecedented levels of executive compensation, with little apparent financial downside risk or relationship of this compensation to long-term company performance. Finally, there is a widespread public perception of unfairness associated with the perceived ability of corporate executives to cash in stock even as their companies and the retirement savings of their employees have collapsed. Id.

${ }^{148}$ H.R. 4173, § 953(a) (adding $§ 14(i)$ to the 1934 Securities Exchange Act).

${ }^{149}$ H.R. 4173, § 953(b)

150 Eric Wahlgren, Spreading the Yankee Way of Pay, Bus. WK., Apr. 18, 2001, http://www.businessweek. com/careers/content/apr2001/ca20010419_812.htm. (The article further reported that, for Britain, the CEO ratio was only 25 and for France, only 16.)

${ }^{151}$ H.R. 4173, § 956 (a), (b) (emphasis added).

${ }^{152}$ H.R. 4173, $§ 955$ (adding $§ 14$ (j) to the 1934 Securities Exchange Act). 
The Act also adds a non-binding shareholder vote on compensation every three years. ${ }^{153}$

These provisions are mainly window dressing to create the impression that Congress has done something about executive compensation. What is really needed, at a minimum, is a rigorous clawback $^{154}$ provision such that, when history shows that bonuses or stock options were not earned, the company can recoup the compensation paid or void the options granted.

The Act makes a token step in that direction. It provides that, when a company is required to restate its financial statements because of material non-compliance with the disclosure requirements of the securities laws, the company may recover from any current or former executive officer "who received incentive-based compensation during the 3-year period preceding the date on which the issuer is required to prepare an accounting restatement based on the erroneous data" in excess of that which would have been paid to the executive officer under the accounting restatement. ${ }^{155}$

For this clawback to be triggered, first of all there must be a restatement of earnings; moreover, the restatement must be predicated upon a violation of the disclosure provisions of the securities laws. Then there is the quoted material above: how far back will the clawback reach? Moreover, since this provision applies only to executive officers, it would not cover the traders whose risk-taking contributed to the crisis, but who were extraordinarily well compensated for taking such risks.

Consider Mozilla of Countrywide. His company, under his direction, loosened underwriting standards, beginning in 2003. From January 2004 until mid 2007, the stock soared, as did Mozilla's compensation. The audit of Countrywide's 2007 fiscal year might not be completed until late 2007, or later if a restatement was required. The restatement could be issued in 2008. Would a loosening of underwriting standards compel a restatement? If not, was the restatement required because of a violation of the securities laws? Who would have the burden of proof? What would be the period covered by the clawback. Could it reach back to 2003 or 2004 ?

Or consider the bank bonuses which were given in late 2008 up to the enactment of the American Recovery and Reinvestment Act of 2009. ${ }^{156}$ Kenneth R. Feinberg, the Special Master for TARP Executive Compensation (sometimes referred to as the "Pay Czar"), analyzed \$1.7 billion of

${ }^{153}$ H.R. 4173, § 951 (adding § 14A to the 1934 Securities Exchange Act).

${ }^{154}$ Treasury Guidance, supra note 105, at 30, gives the following explanation of a clawback:

The deferral-of-payment method is sometimes referred to in the industry as a "clawback." The term "clawback" also may refer specifically to an arrangement under which an employee must return incentive compensation payments previously received by the employee (and not just deferred) if certain risk outcomes occur. Section 304 of the Sarbanes-Oxley Act of 2002 (15 U.S.C. 7243), which applies to chief executive officers and chief financial officers of public banking organizations, is an example of this more specific type of "clawback" requirement.

${ }^{155}$ H.R. 4173, § 954 (adding § 10D (b) to the 1934 Securities Exchange Act).

${ }^{156}$ H.R. $1,111^{\text {th }}$ Congress, available at http://thomas.loc.gov/cgi-bin/query/z?c111:H.R.1: 
compensation paid to bank executives who made more than $\$ 500,000$ per year. ${ }^{157}$ Many of these banks had received billions of dollars of payments to keep them afloat from the $\$ 700$ billion bailout fund. ${ }^{158}$ According to press reports, Mr. Feinberg found that $80 \%$ of the compensation was unmerited. ${ }^{159}$ Even though these bonuses, in many instances, were given to the players who helped cause the economic crisis, Mr. Feinberg determined that the payments were legal. ${ }^{160}$

Mr. Feinberg recommended that the compensation committee of a company's board of directors should have the authority to restructure, reduce or cancel pending payments to executives if the company's board of directors has identified that the company is in a crisis situation. This authority would supersede any rights and entitlements executives would otherwise have. But, as discussed above, this places considerable faith in compensation committees. There is concern that this leaves too much discretion with the company. ${ }^{161}$

What is needed is a legislative fix that would require that incentive compensation "earned" in any year "vests" in $20 \%$ increments over five years, and that stock obtained through the exercise of stock options is similarly alienable only in $20 \%$ annual increments. If it were discovered that the compensation was not really earned, the company would be able to void the unexercised portion of the option or cancel the stock still held by the executive, among other remedies. This would convert the horizon of the executive into a long-term one.

The guidance of the federal banking regulators recognized that the deferral is one method to make compensation more sensitive to risk. By deferral is meant:

The actual payout of an award to an employee is delayed significantly beyond the end of the performance period, and the amounts paid are adjusted for actual losses or other aspects of performance that are realized or become better known only during the deferral period. Deferred payouts may be altered according to risk outcomes either formulaically or judgmentally, subject to appropriate oversight. To be most effective, the deferral period should be sufficiently long to allow for the realization of a substantial portion of the risks from employee activities, and the measures of

\footnotetext{
${ }^{157}$ See U.S. Department of Treasury Press Release, The Special Master for TARP Executive Compensation Concludes the Review of Prior Payments, July 23, 2010, available at http://www.financialstability.gov/docs/20100723\%20Lookback\%20release.pdf

${ }^{158}$ See Emergency Economic Stabilization Act of 2008, Pub. L. No. 110-343, 122 Stat. 3765 (2008), available at http://frwebgate.access.gpo.gov/cgi-bin/getdoc.cgi?dbname=110_cong_public_laws\&docid=f:publ343.110. Passed by the Senate on October 1, 2008, the House on October 3, 2008, and signed into law by President Bush on October 3, 2008. For a current review, see Kimberly Amadeo, What Exactly Was the Bank Bailout Bill?, About.com, July 2, 2010, available at http://useconomy.about.com/od/criticalssues/a/govt_bailout.htm

${ }^{159}$ Eric Dash, Federal Report Faults Banks on Huge Bonuses, N.Y. TIMES, July 23, 2010, available at http://www.nytimes.com/2010/07/23/business/23pay.html?th\&emc=th.

${ }^{160}$ Treasury Press Release, supra note 157.

${ }^{161}$ Editorial, Banker's Pay, N.Y. TIMES, July 28, 2010, available at http://www.nytimes.com/2010/07/28/opinion/28wed4.html?th\&emc=th
} 
loss should be clearly explained to employees and closely tied to their activities during the relevant performance period. ${ }^{162}$

A similar approach should be taken with regard to traders. ${ }^{163}$ If they win big in odd years but lose big in even years, there is no benefit to the company, but the risk-taking trader could be handsomely rewarded. It would be preferable if issues such as these could be left to the boards of directors, but directors have not distinguished themselves in building accountability into compensation systems. Since directors frequently are executives of other companies, they have a structural bias in favor of excessive compensation and weak accountability.

\section{c. Inadequate Capitalization}

One of the reasons some financial institutions were in jeopardy was that they had inadequate capital. If capital is inadequate, a drop in the value of the assets an institution holds could render it insolvent. This is illustrated by the simple illustration below, where a bank holds mortgages supposedly worth 90:

\begin{tabular}{lrlr}
$\begin{array}{lrl}\text { Assets } \\
\text { Mortgages }\end{array}$ & 90 & Liabilities & \\
Cash & 10 & Debt (deposits) & \\
\cline { 2 - 4 } Total & 100 & Capital & 20 \\
\cline { 2 - 3 } & & Total & 100
\end{tabular}

But what if those mortgages are only worth 70 instead of 90 ?

\begin{tabular}{lrlr}
$\begin{array}{lrl}\text { Assets } \\
\text { Mortgages }\end{array}$ & 70 & Liabilities & 80 \\
Cash & 10 & Debt (deposits) & \\
\cline { 2 - 3 } Total & 80 & Capital & 0 \\
& & Total & 80
\end{tabular}

At this point, the bank has no capital.

This is essentially what happened in the current financial crisis. As the price of real estate dropped, so did the price of the mortgage-backed securities and collateralized debt obligations. In effect, assets disappeared from the banks balance sheet, leaving capital impaired. Before the crisis, the ratio of total assets to capital for Merrill Lynch and Morgan Stanley went from 19:1 and 22:1, respectively, in

\footnotetext{
${ }^{162}$ Treasury Guidance, supra note 105, at 30-31.

${ }^{163}$ See Treasury Guidance, supra note 105, at 27 (giving the example of "individual employees, including non-executive employees, whose activities may expose the organization to material amounts of risk (e. g., traders with large position limits relative to the organization's overall risk tolerance)").
} 
2000, to 32:1 and 33:1 in 2007. Additionally Bear Stearns's 2007 ratio was even higher at 34: 1, while Lehman Brothers was 31:1. ${ }^{164}$ What this means is that an approximate $3 \%$ drop in the value of assets could impair their capital of these firms. This undercapitalization was facilitated by the SEC, which, in 2004, modified the net capital rules for brokers to enable firms to about double their leverage. ${ }^{165}$

The relationship between the leverage ratio in the necessary drop in the value of the assets to wipe out a bank's capital is illustrated by the graph below: ${ }^{166}$

\section{Decline in assets that will wipe you out at different levels of leverage}

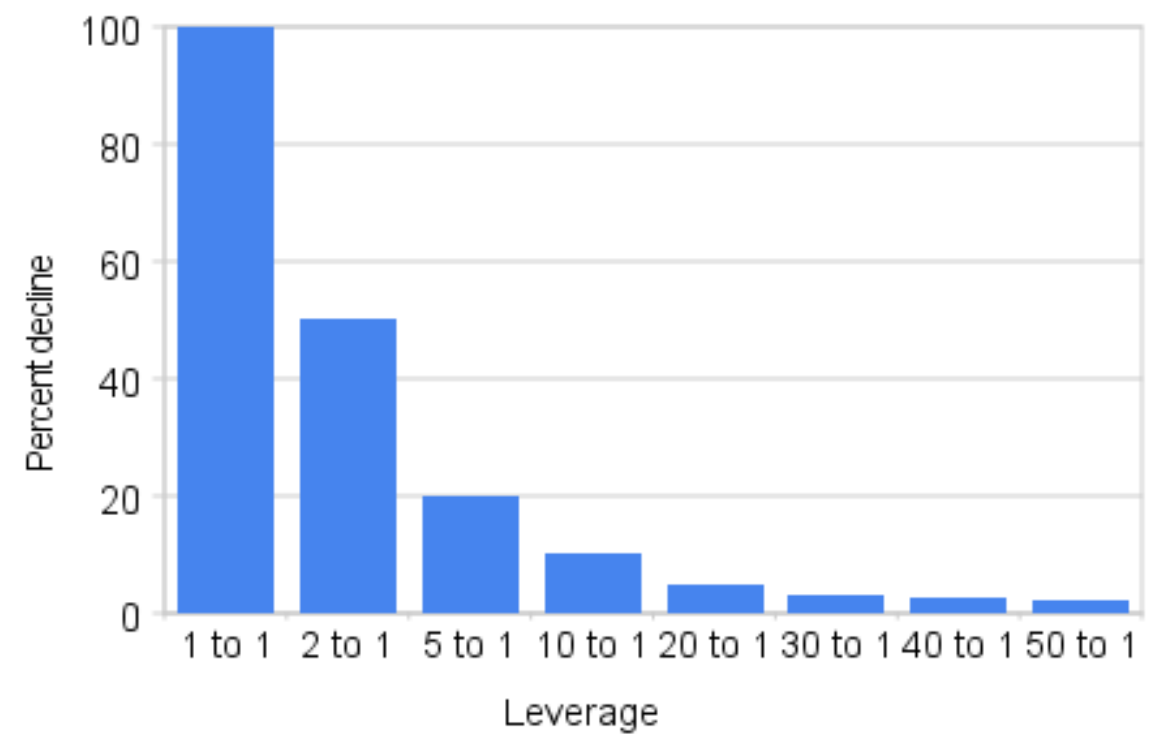

In addition, banks have engaged in what has been referred to as "capital arbitrage," namely, the use of SIVs, or structured investment vehicles, to get assets and liabilities off their balance sheets and have issued something called "trust preferred securities," which are nothing more than additional debt dressed up as equity so that it could be considered capital for the banks. Moreover, banks held AAA rated CDOs to also reduce their capital requirements since AAA mortgage-backed securities required only half the capital that the mortgages themselves would require.

Why is it that the banks wanted to end-run capital requirements? In the old days, referencing the simplified balance sheet above, a bank's assets, there is, mortgages, would be supported by the deposits of the public and the capital provided by shareholders; the bank's income would result from the spread

\footnotetext{
164 See Milken Institute, Demystifying the Mortgage Meltdown: What it Means for Main Street, Wall Street and the U.S. Financial System, Oct. 2, 2008.power point presentation available at http://www.scribd.com/doc/6371820/Milken-InstituteMortgage-Crisis-Overview. See also http://www.boom2bust.com/2008/11/11the-meeting-that-caused-so-much-financialchaos/

${ }^{165}$ See Julie Satow, Ex-SEC Official Blames Agency for Blow-Up of Broker Dealers, NEW YoRK SUN, Sep. 18, 2008, available at http://www.nysun.com/business/ex-sec-official-blames-agency-for-blow-up/86130/. See also Lee A. Pickard, SEC's Old Capital Approach Was Tried and True, 2008 WLNR 14785498.

${ }^{166}$ Ezra Klein, Explaining Financial Regulation: Leverage and Capital Requirements, WASH. PoST, Apr. 19, 2010, available at http://voices.washingtonpost.com/ezra-klein/2010/04/explaining_financial_regulatio.html.
} 
between the interest it received from the mortgages and the interest it was required to pay depositors. But if the bank were required to hold only half the capital, the return on capital would roughly double in contrast with the simple model above.

Under the Basel Accord, ${ }^{167}$ banks were to have an $8 \%$ capital buffer against their risk-adjusted assets. This was a adjusted to $10 \%$ in the United States in order for a bank to be "well capitalized." This would seem to indicate a 10:1 asset/equity ratio, or a 9:1 debt/equity ratio. However the key is the phrase "risk-adjusted assets." AAA rated securities supposedly had half the risk of mortgages, and thus required only half the capital. ${ }^{168}$ This was the driving force for banks holding billions of dollars of AAA rated CDOs which, as events unfolded, were not so riskless.

Another technique to end--run capital requirements was to sell the mortgage loans or CDOs to an SIV. The SIV would fund the purchase with asset-backed commercial paper, which would carry a low interest rate and thus provide an arbitrage profit for the bank. However, the bank had to provide a guarantee to the buyers. Since the guarantees were short term (but were rolled over), the banks were able to end-run the Basel capital requirements. Thus, the assets were supposedly off the balance sheet of the banks for regulatory purposes, but the bank still had the liability therefore.

A third technique to end-run regulatory capital requirements was to issue something called trust preferred securities. The securities are a hybrid of a debt security issued by a bank to a trust or subsidiary it creates, and a preferred stock issued by the trust. The bank seeks to deduct the interest paid on the debt for tax purposes, but can count the debt as capital for regulatory purposes since it is subordinated to all other debt. As of 2007 , there was about $\$ 160$ billion of such securities outstanding. ${ }^{169}$ Today, many trust preferred securities are trading at a fraction of their issue price. ${ }^{170}$ While major banks, such as Citicorp, ${ }^{171}$ issued of billions of dollars in such securities, between 2000 and 2008, more than 1500 small and regional banks issued about $\$ 50$ billion. $^{172}$

The response of the Financial Reform Act once again is basically to punt to the regulators. Section 171 of the Act provides that the appropriate federal banking agencies shall establish "minimum

\footnotetext{
${ }^{167}$ The recommendations by the Basel Committee On Banking Supervision Of the Bank of International Settlements, in Basel Switzerland. See also Council of Mortgage Lenders, Basel II - A Guide to Capital Adequacy Standards for Lenders, updated May 28, 2010, available at http://www.cml.org.uk/cml/policy/issues/748
}

\footnotetext{
${ }^{168}$ Viral V. Acharya \& Matthew Richardson, Causes of the Financial Crisis, 21 CRITICAL REVIEW 195, 202 (2009), available at http://www.cepii.fr/anglaisgraph/communications/pdf/2009/14150909/Session\%202\%20-\%20P\%20\%20Viral\%20Acharya-2\%5B1\%5D.pdf
}

${ }^{169}$ Bill Sammoa, Raising Capital Via Trust Preferred Securities, Capital Markets, Mar. 2008, available at http://www.howebarnes.com/pdf/CapMktsMarch08.pdf.

${ }^{170}$ Andrew Bary,It Only Looks like a Wipeout, BARRON's, Feb. 9,2009, available at http://online.barrons.com/article/SB123397130260259379.html.

${ }^{171} I d$.

${ }^{172}$ Robin Sidel, Big Problem for Small Banks-- Trust-Preferreds, WALL STREET JOURNAL ONLINE Feb. 12, 2010 , available at http://online.wsj.com/article/NA_WSJ_PUB:SB10001424052748703455804575057510391065200.html 
leverage capital requirements" 173 (the numerator of which includes the regulatory capital components and denominator of which includes the average total assets) ${ }^{174}$ and "minimum risk-based capital requirements." 175 These cannot be less than the "generally applicable" requirements, which are tied into the regulation of insured depository institutions "under the prompt corrective action regulations implementing section 38 of the Federal Deposit Insurance Act.",176

While this leaves most of the determinations to the regulators, since trust preferred securities have not been counted as capital for depositary institutions, in effect this precludes the use in the future of trust preferred securities as capital. These provisions were inserted as a result of an amendment proposed by Sen. Susan Collins. ${ }^{177}$ Since she was concerned about smaller banking institutions and wanted to level the playing field for smaller banks, the Act as agreed to in conference provided that small bank holding companies, i.e., with less than $\$ 500$ million of assets, would be permitted to continue to use these securities and have them count as tier 1 capital; it also grandfathered securities issued before May 19, 2010 for bank holding companies with less than \$15 billion of assets and provided a three-year phase-in period for larger bank holding companies. ${ }^{178}$

The foregoing was not an entirely satisfactory solution for many who were concerned with the federal regulators failure to arrest excessive leverage in the past. Representative Speier sought to include a measure that would have capped leverage at large financial institutions at 15:1. She stated that "high leverage has been shown to have been one of the best predictors of major financial firms' falling into distress or needing government support during the current crisis. I believe that it is a mistake to leave all discretion in how to accomplish that task to the primary regulators." ${ }^{179}$ Nevertheless, the basic issue of adequate capital for financial institutions has been left to the regulators.

\section{d. Proprietary Trading and the Volcker rule}

Paul Krugman, a Nobel prize-winning economist, has opined that commercial banking ought to be boring. ${ }^{180}$ And so it was, from 1933 when the Glass-Steagall act was passed until 1980 when President Reagan opined that "government is not the solution; government is the problem" 181 and began

\footnotetext{
${ }^{173}$ H.R. 4173, § 171 (b)(1).

${ }^{174}$ H.R. 4173, § 171 (a)(1)(B).

${ }^{175}$ H.R. 4173, § 171 (b)(2).

${ }^{176}$ H.R. 4173, § 171 (a)(1)(A) \& (a)(2)(A) .

${ }^{177}$ Independent Bankers Association of Texas, Clarity on the Collins Amendment, May 24, 2010, available at http://www.ibat.org/news/2010/05/24/clarity-collins-amendment.

${ }^{178}$ H.R. 4173, § $171(\mathrm{~b})(4),(5)$.

${ }^{179}$ Ronald D.Orol, How a Cap on Big-Bank Leverage Was Watered down, MARKET WATCH, July 13, 2010, available at http://www.marketwatch.com/story/story/print?guid=77F02012-3252-416C-95DF-1679466F39B0.
}

\footnotetext{
${ }^{180}$ Paul Krugman, Good and Boring, N.Y. TIMES Jan. 31,2010, available at http://www.nytimes.com/2010/02/01/opinion/01krugman.html.
}

${ }^{181}$ Pres. Ronald Reagan, First Inaugural Address, Jan. 20, 1981. 
deregulating the financial industry. This resulted in the savings and loan crisis of the 1980s. In the 1990s, President Clinton, at the urging of Chairman Greenspan, secretary of the treasury Rubin, and his deputy, Lawrence Summers, accomplished the repeal of Glass-Steagall ${ }^{182}$ and thwarted efforts by Brooksley Born, the chair of the Commodities Futures Trading Commission, to regulate derivatives. ${ }^{183}$ This was a major contributor to the current financial crisis.

While it has proved profitable in the short run, the marriage of commercial banking investment banking is actually a marriage made in hell. There are two entirely different risk profiles associated with the two types of banking. Commercial banking ought to be conservative or, as Mr. Krugman suggests, boring, with a focus on lending and protecting the safety of the public's deposits. One reason that collateralized loan obligations ("CLOs") have not had the default history of the CDOs is that the loans undergirding the former were made to businesses with whom the commercial lender typically had a long-standing relationship, the commercial lender did due diligence, and the lender kept a piece of the action. On the other hand, CDOs typically involved residential mortgage loans made by a non-bank lender with no relationship to the borrower, who cared less about the underlying safety of the loan, and who sold it to get rid of the risk. CLOs represented appropriate risk; CDOs represented excessive risk.

Consider now investment banks; these banks no longer make the bulk of their earnings from underwriting public offerings, but rather from trading activities. ${ }^{184}$ By their very nature, trading is a risky enterprise with the possibility of millions being earned or lost on a particular trade. It was the investment banking mentality, imported into banks such as Citicorp, and their subsequent bailout by the federal government, that led to charges that profit has been privatized and risk has been socialized.

The Volcker rule, ${ }^{185}$ which would have in part separated trading activities and banking activities, was supposedly dead in the water in early $2010 .{ }^{186}$ However, while there are different views as to the

\footnotetext{
${ }^{182}$ Daniel Gross, Shattering the Glass-Steagall, Sept. 15, 2008, available at

http://www.google.com/search?sourceid=navclient\&ie=UTF-

8\&rlz=1T4ADRA_enUS386US387\&q=Slate+shattering+the+Glass-Steagall

${ }^{183}$ See Brooskley Born \& the Regulatory Limit of Democrats, (Nov. 11, 2008), available at http://cobb.typepad.com/cobb/2008/11/brooksley-born.html; Peter S. Goodman, Taking Hard New Look at a Greenspan Legacy, N.Y. TIMES, Oct. 8, 2008, available at http://www.nytimes.com/2008/10/09/business/economy/09greenspan.html.

${ }^{184}$ See, for example, Brady Dennis, JP Morgan reports 57\% Jump in Quarterly Profit, WASH. POST., APRIL 15,2010 ("Trading profits at its investment bank helped offset continued consumer credit losses tied to mortgages and credit cards."), available at http://www.washingtonpost.com/wp-dyn/content/article/2010/04/14/AR2010041400981.html; Bloomberg Business Week, Morgan Stanley Shares Rise Most in a Year on Earnings, Aug,. 1, 2010 ("Trading is still the predominant driver of Morgan Stanley's business" $-\$ 1.42$ billion in equity trading; $\$ 1.7$ billion in fixed-income sales and trading; $\$ 885$ million from investment banking), available at http://www.businessweek.com/news/2010-07-21/morgan-stanley-shares-risemost-in-a-year-on-earnings.html.

${ }^{185}$ See FINANCIAL TIMES LEXICON, available at http://lexicon.ft.com/term.asp?t=Volcker-rule:
}

This proposal, announced by US President Barack Obama, aims to limit risky behaviour within banks but is narrower than the Glass-Steagall Act. Banks that take retail deposits would not be allowed to engage in proprietary trading that is not directly related to the market making and trading they do for customers. These banks would also be prohibited from owning or sponsoring hedge funds or private equity funds.

${ }^{186}$ See Volcker Rule Unexpectedly Revived by Dodd Bill, Reuters, Mar. 16, 2010, available at
http://blogs.reuters.com/great-debate/2010/03/16/volcker-rule-unexpectedly-revived-by-dodd-bill/. 
extent proprietary trading contributed to the financial meltdown, ${ }^{187}$ a version of the Volcker rule was incorporated into the Financial Reform Act.

Section 619 of the Financial Reform Act begins boldly by adding section 13 to the Bank Holding Company Act $^{188}$ to impose what appears to be an absolute prohibition on proprietary trading and holding an interest in or sponsoring a hedge fund or a private equity fund:

(a) In general:

(1) Prohibition - Unless otherwise provided in this section, a banking entity shall not -

(A) engage in proprietary trading; or

(B) acquire or retain any equity, partnership, or other ownership interest in or sponsor a hedge fund or a private equity fund. ${ }^{189}$

This seemingly absolute prohibition is also applied to non-bank financial companies. But, the key words are "in general" and "unless otherwise provided." The Act then mandates a six-month study and followup rule-making that, in effect, will defer the effectiveness of the amendment for two years after enactment..$^{190}$

This is followed by a series of exceptions, designated as "permitted activities,"191 and a "de minimis" provision, which will probably become the rule. De minimis is defined as not more than $3 \%$ of the total ownership interests in the fund or not more than $3 \%$ of the Tier 1 capital of the banking entity. ${ }^{192}$ The banking entity is required to meet the $3 \%$ investment limitation within one year after the establishment of the fund; ${ }^{193}$ however, the one year period can be extended by two years. ${ }^{194}$

Thus, it will be years before the effectiveness of this provision can be evaluated.

\section{e. Too Big to Fail and Stemming Systemic Risk}

The reason that companies are "too big to fail," is that their failure involves systemic risk, that is, it impacts the rest of the economic system. Consider the Lehman Brothers bankruptcy, which was a

\footnotetext{
${ }^{187}$ Heidi N. Moore, Citigroup: Volcker Rule or Volcker Suggestion? CNN Money, July 8, 2010, available at http://wallstreet.blogs.fortune.cnn.com/2010/07/08/citigroup-volcker-rule-or-volcker-suggestion/.

${ }^{188} 12$ U.S.C. 1841 et seq.

${ }^{189}$ H.R. 4173, § 619.

${ }^{190}$ H.R. 4173, § 619 (adding $§ 13$ (b), (c).

${ }^{191}$ H.R. 4173, § 619 (adding $§ 13$ (d)(1) (A)-(J).

${ }^{192}$ H.R. 4173, § 619 (adding $§ 13$ (d)(4).

${ }^{193}$ H.R. 4173, § 619 (adding $§ 13$ (d)(4)(B)(ii).

${ }^{194}$ H.R. 4173, § 619 (adding $§ 13$ (d)(4)(C).
} 
result of the firm's involvement in the subprime mortgage debacle. This resulted in a money market fund, The Primary Reserve Fund, "Breaking the Buck," that is, the value of a share in the mutual fund fell below one dollar. ${ }^{195}$ Money is invested or borrowed in a money market system on a short-term basis, sometimes overnight. While the return is not as much for a long-term investment, investors do not expect to lose any money. Money market funds are regarded as totally safe. Companies park their money overnight and rely upon them as a source of credit when they need short-term funds. All companies oscillate between having cash on hand and needing to borrow cash on a particular day.

Thus, when the Lehman Brothers debt was written down, first to $\$ .80$ on the dollar and then to zero, it created a panic as investors rushed to get their money out of money market funds. The result was that the commercial paper market, the most liquid in the world, began to freeze up. This then affected financial institutions and businesses around the country. "Money stopped moving. Big, safe, respected companies far away from all the subprime lending problems had trouble getting the short-term loans they needed to pay their bills." 196 Fortunately, the freeze only lasted for about 12 hours. Chairman Bernanke feared that, had it lasted for days or weeks, the consequences would be worse than the Great Depression. ${ }^{197}$

The same day that the Reserve Fund broke the buck, the Fed stepped in with an $\$ 85$ billion loan to AIG, fearful that the lack of liquidity for the firm, which was facing collateral calls from its counterparties, could force it into bankruptcy. AIG also presented systemic risk because, if it did not honor its hundreds of billions of dollars in credit default swaps, its numerous counterparties would suffer devastating losses. Two day's later, on September 18, Secretary Paulson and Chairman Bernanke went to Congress seeking the $\$ 700$ billion financial bailout. ${ }^{198}$

From the foregoing, it is clear that systemic risk is a reality and that steps need to be taken so that it does not lead to a financial meltdown in the future.

\footnotetext{
195 Diana B. Henriques, Buck Broken, but Timing May Affect Reductions, N.Y. Times, Nov. 27, 2008, available at http://www.nytimes.com/2008/11/27/business/27fund.html.
}

${ }^{196}$ National Public Radio, The Week America's Economy Almost Died, Sept. 26, 2008, available at http://www.npr.org/templates/story/story.php?storyId=95099470.

${ }^{197} I d$.

${ }^{198}$ See David M. Herszenhorn, Administration Is Seeking $\$ 700$ Billion for Wall Street, N.Y. TIMES, Sep. 20, 2008, available at http://www.nytimes.com/2008/09/21/business/21 cong.html?_r=1. Paulson presented Congress with a three-page bill that totally exculpated him from any responsibility. See Text of Draft Proposal for Bailout Plan, (Sep. 20, 2008), available at http://www.nytimes.com/2008/09/21/business/21draftcnd.html?ref=business; see also Bailout Bill: Full Text of Plan, THE HUFFINGTON POST, Sep. 28, 2008, available at http://www.huffingtonpost.com/2008/09/28/bailout-legislation-

full_n_130063.html. Congress ultimately enacted a 451 page bill, The Emergency Economic Stabilization Act of 2008, which President Bush signed into law in early October. Emergency Economic Stabilization Act of 2008, Pub. L. No. 110343, 122 Stat. 3765 (2008), available at http://frwebgate.access.gpo.gov/cgi-

bin/getdoc.cgi?dbname=110_cong_public_laws\&docid=f:publ343.110. Passed by the Senate on October 1, 2008, the House on October 3, 2008, and signed into law by President Bush on October 3, 2008. 
There are two aspects with regard to "too big to fail." One is to have a mechanism outside bankruptcy for the government to take over the about to fail institution; another is to ensure that no institution is too big to fail. Arguably, if it is too big to fail, it is too big. ${ }^{199}$

The "too big to fail" concept apparently originated with C. T. Conover's testimony in connection with the failure of Continental Illinois National Bank when he stated that he would not let the 11th largest bank fail. ${ }^{200}$ This created an implicit guarantee for large banks. But after the financial bailout in 2008, Sheila Blair, the head of the FDIC, stated that the guarantee, which had been implicit, was now explicit and was giving large banks a competitive advantage. ${ }^{201}$ The Center for Economic and Policy Research estimated that the taxpayer subsidy for large banks was \$34 billion a year, a substantial advantage over smaller banks, as stated above. ${ }^{202}$

The systemic risk posed by the financial sector is a function of both its size and its concentration. Commercial banks in 1978 held $\$ 1.2$ trillion of assets, about 53\% of U.S. GDP. By 2007, their assets had grown to $\$ 11.8$ trillion, or $84 \%$ of GDP. ${ }^{203}$ The assets of the six largest banks, Bank of America,

\footnotetext{
${ }^{199}$ See Michael McKee \& Scott Lanman, Greenspan Says U.S. Should Consider Breaking up Large Banks, BLOOMBERG, Oct. 15, 2009 ("If they're too big to fail, they're too big," Greenspan said today), available at http://www.bloomberg.com/apps/news?pid=newsarchive\&sid=aJ8HPmNUfchg
}

\begin{abstract}
${ }^{200}$ Conover, Charles (1984). "Testimony". Inquiry Into the Continental Illinois Corp. and Continental National Bank: Hearing Before the Subcommittee on Financial Institutions Supervision, Regulation, and Insurance of the Committee on Banking, Finance, and Urban Affairs. U.S. House of Representatives, 98th Congress, 2nd Session, 18-19 September and 4 October. pp. 299-300, available at http://fraser.stlouisfed.org/historicaldocs/678/download/63823/house_cinb1984.pdf. See also FDIC, HISTORY OF THE 80s - LESSONS FOR THE FUTURE, Ch. 7, Continental Illinois and "Too Big to Fail," available at http://www.fdic.gov/bank/historical/history/235_258.pdf.

\footnotetext{
${ }^{201}$ Paul Wiseman and Paliavi Gogoi, FDIC Chief: Small Banks Can't Compete with Bailed-out Giants, Oct. 20, 2009, available at http://www.usatoday.com/money/industries/banking/2009-10-19-FDIC-chief-sheila-bair-banking_N.htm.

${ }^{202}$ Dean Baker \& Travis MacArthur, The Value of the "Too Big to Fail” Big Bank Subsidy, CENTER FOR ECONOMIC AND
} POLICY RESEARCH, Sept. 2009:
\end{abstract}

The spread between the average cost of funds for smaller banks and the cost of funds for institutions with assets in excess of $\$ 100$ billion averaged 0.29 percentage points in the period from the first quarter of 2000 through the fourth quarter of 2007, the last quarter before the collapse of Bear Stearns. In the period from the fourth quarter of 2008 through the second quarter of 2009, after the government bailouts had largely established TBTF as official policy, the gap had widened to an average of 0.78 percentage points.

If this gap is attributable to the TBTF policy, it implies a substantial taxpayer subsidy for the TBTF banks. In effect, because of the government safety net being extended to investors who lend money to these banks, the TBTF banks are able to borrow at a much lower cost than banks who must borrow based on their own credit worthiness. The increase in the gap of 0.49 percentage points implies a government subsidy of $\$ 34.1$ billion a year to the 18 bank holding companies with more than $\$ 100$ billion in assets in the first quarter of 2009 .

available at http://www.cepr.net/documents/publications/too-big-to-fail-2009-09.pdf. Andrew Haldane, the Bank of England's executive director in charge of financial stability, estimated the subsidy that Britain's largest banks enjoy at between $£ 30$ billion and $£ 55$ billion. Britain Questions “Too Big to Fail," N.Y. TIMES, Apr. 1, 2010.

\footnotetext{
${ }^{203}$ Simon Johnson \& James Kwak, 13 BANKERS - THE WALL STREET TAKEOVER AND THE NEXT FinANCIAL MELTDOWN (2010), at 59 .
} 
J.P. Morgan Chase, Citigroup, Wells Fargo, Goldman Sachs, and Morgan Stanley, grew from under $20 \%$ of GDP to over $60 \% .{ }^{204}$ Banking was no longer boring. From the 1930 s until 1980, profits in the financial sector grew roughly at the same rate as profits in the nonfinancial sector. But from 1980 until 2005 , financial sector profits grew by $800 \%$, whereas profits any other sectors grew by only $250 \% .{ }^{205}$ Prior to 1982, compensation in the financial sector approximated that in the nonfinancial sector; however, by 2007, the financial sector compensation was twice that of other sectors. ${ }^{206}$

The fact that the subsidy provided by too big to fail provides a competitive advantage to the big banks has been discussed above. This obviously also increases potential taxpayer costs. But from a longterm perspective, it encourages management to engage in excessive risk-taking since, as demonstrated by recent history, management scores in the short term without consequences of the long term. Richard W. Fisher, the president of the Federal Reserve Bank of Dallas, has stated that "[t]he social costs associated with these big financial institutions are much greater than any benefits they may provide. We need to find some international convention to limit their size."207

When former chairman Greenspan made his comment "If they're too big to fail, they're too big" before the Council on Foreign Relations, he added "So I mean, radical things, as you -- you know, break them up, you know. In 1911, we broke up Standard Oil. So what happened? The individual parts became more valuable than the whole. Maybe that's what we need."208 That would certainly seem the most direct way to deal with the "too big" part of the "too big to fail" equation. The U.S. mentality needs to realize that bigness is problematic, particularly unregulated size. While our federal courts have turned the Sherman Act into an economic exercise, the driving force behind it was a political concern about untrammeled power.

So how do you put limits on size? One author has suggested that the assets of a commercial bank be limited to $4 \%$ of GDP, or roughly $\$ 570$ billion. ${ }^{209}$ That certainly is not small! With respect to investment banks, the author would limit their size to $2 \%$ of GDP, or about $\$ 285$ billion. ${ }^{210}$ These limits would only affect six banks: Bank of America (16\% of GDP), J.P. Morgan Chase (14\% of GDP), Citigroup (13\% of GDP). Wells Fargo (9\% of GDP), Goldman Sachs (6\%) and Morgan Stanley (5\%). ${ }^{211}$

${ }^{204} I d$. at 203.

${ }^{205} I d$. at 60 ; chart at 61 .

${ }^{206} I d$. at 60;- 61 .

${ }^{207}$ Gretchen Morgenstern, Do You Have Any Reforms in Size XL?, N.Y. TIMES, APR. 23,2010, available at http://www.nytimes.com/2010/04/25/business/economy/25gret.html.

208 Alan Greenspan, C. Peter McColough Series on International Economics: The Global Financial Crisis: Causes and Consequences, COUNCIL ON FOREIGN RELATIONS, OCT. 15 2009, available at http://www.cfr.org/publication/20417/c_peter_mccolough_series_on_international_economics.html.

${ }^{209}$ Simon Johnson \& James Kwak, note 203, supra, at 214.

${ }^{210} I d$. at 215 .

${ }^{211} I d$. at 217. 
Smaller banks would increase competition, limit systemic risk, decentralize decision-making and political power, provide more choice for consumers and, if Chairman Greenspan is correct, increase profitability. The argument to the contrary is that large, multinational corporations need large banks. But, at present, these corporations are often serviced by a consortium of banks, so that should not be a disabling argument.

Paradoxically part of the size of these large banks is attributable to the aftermath of the financial crisis. Bank of America acquired Countrywide and Merrill Lynch, and grew 138\%; J.P. Morgan Chase acquired Bear Stearns and Washington Mutual, and grew 51\%; and Wells Fargo acquired Wachovia, and grew $43 \% .^{212}$ A previous conglomeratization phase occurred during the deregulatory mindset of President Clinton. For example, Wachovia was formed from mergers of First Union, CoreStates, and Wachovia, and Citicorp added Travelers Insurance, Primerica, and Salomon Brothers. ${ }^{213}$

Unfortunately, the Financial Reform Act provisions are woefully inadequate with respect to the "too big" aspect. Section 622 of the Financial Reform Act deals with "Concentration Limits on Large Financial Firms." 214 In amends the Bank Holding Company Act by providing a broad definition to the term "financial company," and then provides that a financial company shall not merge or consolidate, acquire substantially all the assets or otherwise control another company "if the total consolidated liabilities of the acquiring financial company upon consummation of the transaction would exceed $10 \%$ of the aggregate consolidated liabilities of all financial companies," measured at the end of the preceding calendar year $^{215}$ It then restricts any interstate merger if "the resulting insured depository institution ... would control more than $10 \%$ of the total amount of deposits of insured depository institutions in the United States." 216 It also restricts a bank holding company from acquiring a depository institution if the bank holding company "would control more than $10 \%$ of the total amount of deposits."217 Finally, it restricts a savings and loan holding company from acquiring an insured depository institution if it would control "more than $10 \%$ of the total amount deposits insured depository institutions in the United States. $^{218}$

The problem with these provisions is that each of them is immediately followed by a provision that negates the limits if the acquisition involves an insured depository institution "in default or in danger of default." As can be seen from the data above, many of the existing large banking institutions grew even larger by acquiring failing institutions. In addition, the Act would not deal with institutions

\footnotetext{
${ }^{212}$ David Cho, Banks “Too Big to Fail” Have Grown Even Bigger, WASH. PosT., AUG. 28, 2009, available at http://www.washingtonpost.com/wp-dyn/content/article/2009/08/27/AR2009082704193.html.

${ }^{213}$ Simon Johnson \& James Kwak, note 203, supra, at 85.

${ }^{214}$ H.R. 4173, § 622.

${ }^{215}$ H.R. 4173, $§ 622$ (adding $§ 14$ (a), (b) to the Bank Holding Company Act (12 U. S. C. 1843)).

${ }^{216}$ H.R. 4173, § 623(a) (adding $§(13)(A)$ to $§ 18$ (c) of the Federal Deposit Insurance Act (12 U. S. C. 1828 (c)).

${ }^{217}$ H.R. 4173, § 623(b) (adding $§ 4$ (i)(8) (A)(a) to the Bank Holding Company Act).

${ }^{218}$ H.R. 4173, § 623(c) (adding $§ 10(\mathrm{e})(2)(\mathrm{E})$ to the Homeowners Loan Act (12 U. S. C. 1467)).
} 
that already exceed the $10 \%$ limit. Each of the three institutions discussed above obtained waivers of the $10 \%$ limit on deposits.

However, with respect to the "fail" aspect of too big to fail, the Financial Reform Act is a landmark change by providing governmental authority to take over a failing financial institution and thereby prevent the institution from going into bankruptcy. Former Secretary Paulson, when asked if the new Act would have prevented to the current crisis, responded that "[w]e would have loved to have something like this for Lehman Brothers. There's no doubt about it.",219

Title I of the $\mathrm{Act}^{220}$ creates a Financial Stability Oversight Council and Title II ${ }^{221}$ provides for orderly liquidation authority. In brief, the Council is composed of 10 voting members and five nonvoting members, ${ }^{222}$ whose role is to "identify risks to the financial stability of the United States," to promote market discipline by eliminating expectations that the government will bailout institutions in the future, and to respond to emerging threats to the financial system. ${ }^{223}$ To accomplish this, the Council is to collect information, monitor the financial services marketplace, identify gaps in regulation, and probably most important "make recommendations to the Board of Governors concerning the establishment of heightened prudential standards for risk-based capital, leverage, liquidity, contingent capital, resolution plans and credit exposure reports, concentration limits, enhanced public disclosures, and overall risk management for nonbank financial companies and large, interconnected bank holding companies supervised by the Board of Governors. "224

If a financial company ${ }^{225}$ were determined to present systemic risk, ${ }^{226}$ the FDIC can be appointed receiver of the company. This could be done either with the consent of the board of directors ${ }^{227}$ or pursuant to a court order in a nonpublic hearing, in which the receivership must be granted so long as the determination of the Secretary of Treasury is not "arbitrary and capricious." 228 The receiver is to take

${ }^{219}$ Andrew Ross Sorkin, Paulson Likes What He Sees in Overhaul, N.Y. TIMES, July 13, 2010, available at http://dealbook.blogs.nytimes.com/2010/07/13/paulson-likes-what-he-sees-in-overhaul/.

${ }^{220}$ H.R. 4173, $§ \S 101-176$.

${ }^{221}$ H.R. 4173, $§ \S 201-217$.

${ }^{222}$ H.R. 4173, § 111(b).

${ }^{223}$ H.R. 4173, § 11(a)(1).

${ }^{224}$ H.R. 4173, § 11(a)(2) (A), (C), (G), \& (I).

${ }^{225}$ H.R. 4173, § 201(a) (11) (the definition includes bank holding companies, non-bank financial companies supervised by the board of governors, any company that is predominantly engaged in activities determined to be financial in nature or incidental thereto, and a subsidiary of the foregoing).

${ }^{226}$ This recommendation is made by the FDIC, either on its own motion or pursuant to request from the Secretary of the Treasury, and the Board of Governors of the Federal Reserve. In the case of broker dealer, it is the SEC, not the FDIC, that would make the recommendation and, in the case of an insurance company, it is the director of the Federal Insurance Office that would make the recommendation. The procedures for the systemic risk determination are set forth in $\S 203$.

${ }^{227}$ H.R. 4173, § 202(a)(1)(A)(i).

${ }^{228}$ H.R. 4173, § 202(a)(1)(A)(iv). 
over the assets of the company and operate it while it is in the receivership, ${ }^{229}$ and has broad authority to sell selected assets of the company or arrange for the acquisition of the company. ${ }^{230}$ It can also create a "bridge financial company" to succeed to certain assets and liabilities, as an interim measure pending a permanent transaction with a private acquirer. ${ }^{231}$ The receiver has the authority to establish priorities and to sue to set aside fraudulent transfers and preferences, similar to the authority contained in the bankruptcy code. ${ }^{232}$ The board of directors and senior management must to be replaced, ${ }^{233}$ and management can be held responsible for the financial condition of the company. ${ }^{234}$ A director or senior executive officer can also be barred for up to two years from any affiliation with any financial company if it is determined that such person has violated any law or regulation, or has engaged or participated in any unsafe or unsound practice, or has committed a breach of fiduciary duty. ${ }^{235}$

One of the issues raised as the legislation was being considered, and even after it was signed into law, was whether it would increase the likelihood of future government bailouts. ${ }^{236}$ However, the Financial Reform Act specifically provides that all companies put into receivership shall be liquidated, that all funds expended in the liquidation will be recovered from the assets of the financial company or shall be the responsibility of the financial sector through assessments, and that the taxpayer shall bear no losses from the exercise of any authority under the receivership provisions. ${ }^{237}$

\section{The Financial Reform Act's More Aggressive Approach toward the Credit Rating Agencies}

The current financial crisis also would not have occurred had it not been for the ineptitude, if not concupiscence, of the credit rating agencies. Recall the comment: "[1]et's hope we are all wealthy and retired by the time this house of cards falters."238 Since the reputation of the credit rating agencies was in

\footnotetext{
${ }^{229}$ H.R. 4173, § 210(a)(1)(B).

${ }^{230}$ H.R. 4173, § 210(a)(1)(F).

${ }^{231}$ See H.R. 4173, $\S$ 201(a)(3) (definition) and 210(h) (procedures and powers). The duration of a bridge company is limited to two years, unless extended by the FDIC. See $\$ 210(\mathrm{~h})(12)$. The reason for this short duration is because the purpose of a bridge company is to serve as a vehicle for an ultimate transfer to a private buyer.

${ }^{232}$ See H.R. 4173, $\$ \S 210$ (b) (priority of expenses and unsecured claims) and 210(a)(11) (avoidable transfers).

${ }^{233}$ H.R. 4173, § 206(4)(5).

${ }^{234}$ H.R. 4173, § 210(f) (the standard for liability is gross negligence).

${ }^{235}$ H.R. 4173, § 213.

${ }^{236}$ See supra, text at note 7 (comments of Rep. John Boehner).

${ }^{237}$ H.R. 4173, § 214.

238 SEC, SUMMARY REPORT OF ISSUES IDENTIFIED IN THE COMMISSION STAFF'S

EXAMINATIONS OF SELECT CREDIT RATING AGENCIES, at 12 n.8 (2008)(e-mail from one analytic manager to a senior analytic manager at a credit rating agency; the e-mail also refers to the credit rating agencies having created a "monster"), available at http://www.sec.gov/news/studies/2008/craexamination070808.pdf.
} 
tatters, it is not surprising that the Financial Reform Act took a principled approach in seeking to preclude a repetition of the ratings debacle. Professor Partnoy has stated that the agencies "are not information intermediaries who survive and prosper based on the quality of their ratings. Instead, they have shifted from selling information to selling regulatory licenses.",239

\section{a. The Credit Rating Agencies, the First Amendment, and Civil Liability}

Subtitle C of Title IX of the Financial Reform Act deals with the credit rating agencies. The provisions start with a series of findings that are devastating and that should undercut the argument of the rating agencies that their ratings are protected as free speech under the First Amendment. ${ }^{240}$ The findings ${ }^{241}$ refer to "the systemic importance of credit ratings and the reliance placed on them," and assert that the rating agencies "play a critical 'gatekeeper' role in the debt market that is functionally similar to that of securities analysts." Congress then found that, since the rating agencies provide services on behalf of clients similar to other financial gatekeepers, "the activities of credit rating agencies are fundamentally commercial in character and should be subject to the same standards of liability and oversight as apply to auditors, securities analysts, and investment bankers.”

This finding should vitiate the rating agencies' First Amendment argument that they should have no civil liability. The findings further noted the conflicts of interest that occurred when the agencies advised underwriters of structured financial products on how to secure a desired rating and further found

\footnotetext{
${ }^{239}$ Statement of Professor Frank Partnoy, Roundtable to Examine Oversight of Credit Rating Agencies, Apr. 15, 2009 available at http://www.sec.gov/comments/4-579/4579-6.pdf.
}

\footnotetext{
${ }^{240}$ See Standard \& Poor's Ratings Services Statement, supra, note 116 ("Today, credit rating agencies are free to develop and publish their credit rating opinions under strong First Amendment protections.)
}

${ }^{241}$ The complete findings, set forth in H.R. $4173 \S 931$, are: “(1) Because of the systemic importance of credit ratings and the reliance placed on credit ratings by individual and institutional investors and financial regulators, the activities and performances of credit rating agencies, including nationally recognized statistical rating organizations, are matters of national public interest, as credit rating agencies are central to capital formation, investor confidence, and the efficient performance of the United States economy. (2) Credit rating agencies, including nationally recognized statistical rating organizations, play a critical "gatekeeper" role in the debt market that is functionally similar to that of securities analysts, who evaluate the quality of securities in the equity market, and auditors, who review the financial statements of firms. Such role justifies a similar level of public oversight and accountability. (3) Because credit rating agencies perform evaluative and analytical services on behalf of clients, much as other financial "gatekeepers" do, the activities of credit rating agencies are fundamentally commercial in character and should be subject to the same standards of liability and oversight as apply to auditors, securities analysts, and investment bankers. (4) In certain activities, particularly in advising arrangers of structured financial products on potential ratings of such products, credit rating agencies face conflicts of interest that need to be carefully monitored and that therefore should be addressed explicitly in legislation in order to give clearer authority to the Securities and Exchange Commission. (5) In the recent financial crisis, the ratings on structured financial products have proven to be inaccurate. This inaccuracy contributed significantly to the mismanagement of risks by financial institutions and investors, which in turn adversely impacted the health of the economy in the United States and around the world. Such inaccuracy necessitates increased accountability on the part of credit rating agencies.” 
that "the ratings on structured financial products have proven to be inaccurate" and that this inaccuracy "contributed significantly to the mismanagement of risks" which impacted the economy of the United States and the world. The foregoing "necessitates increased accountability on the part of the credit rating agencies."

Following up on a foregoing, the Financial Reform Act, in dealing with accountability, sets forth a clear intention that the credit rating agencies are subject both to enforcement actions by the SEC and to private damage actions by injured investors. Section 15E of the 1934 Securities Exchange Act formerly provided that "[n]othing in this section may be construed as creating a private right of action, and no report furnished by nationally recognized statistical rating organization in accordance with this section or section 17 shall create a private right of action under section 18 or any other provision of law.",242 This provision has now been replaced with the following:

The enforcement and penalty provisions of this title shall apply to statements made by a credit rating agency in the same manner and to the same extent as such provisions apply to statements made by a registered public accounting firm or a securities analyst under the securities laws, and such statements shall not be deemed forward-looking statements for the purposes of section $21 \mathrm{E}^{243}$

Not only does this subject credit rating agencies to enforcement and penalty actions by the SEC, but also specifies that the credit rating agencies may not seek to limit their responsibility by claiming that there ratings are forward-looking statements. If they were considered forward-looking statements, the agencies would be exculpated from liability if they accompanied the ratings with a cautionary statement. $^{244}$

The Act likewise makes clear that the credit rating agencies can be subjected to a private cause of action. The "state of mind" or scienter provision with respect to private securities litigation was amended by adding the following:

In the case of an action for money damages brought against a credit rating agency or a controlling person under this title, it shall be sufficient, for purposes of pleading any required state of mind in relation to such action, that the complaint stayed with particularity facts giving rise to a strong inference that the credit rating agency knowingly or recklessly failed -

(i) to conduct a reasonable investigation of the rated security with respect to the factual elements relied upon by its own methodology for evaluating credit risk; or

(ii) to obtain reasonable verification of such factual elements ... from other sources that the credit rating agency considered to be competent and that were independent of the issuer and the underwriter.

\footnotetext{
${ }^{242}$ See 15 U.S.C.A. $\$ 780-7$ (m) (2009).

${ }^{243}$ H.R. 4173, § 933(a) (amending 15 U.S.C. $\$ 780-7$ (m)).

${ }^{244}$ If a cautionary statement were employed, the maker is protected from liability even if such person had actual knowledge that the statement was false or misleading. See Charles W. Murdock, Corporate Corruption and the Complicity of Congress and the Supreme Court - The Tortuous Path from Central Bank to Stoneridge Investment Partners, LLC v. Scientific-Atlanta, Inc, 6 Berk. Bus. L. J. 131, 188-192_(2009).
} 
The specter of an SEC penalty action or a private damage action should have a sobering effect upon the management of the credit rating agencies.

The Financial Reform Act $^{245}$ also sprung a bombshell with respect to the 1933 Securities Act by repealing an SEC rule that had provided that a security rating was not considered part of the registration statement. ${ }^{246}$ This one sentence provision in the Act has the effect of exposing rating agencies to Section 11 liability as an expert. In such a case, the rating agency would have liability for any false or misleading statement unless "after reasonable investigation, [the rating agency had] reasonable ground to believe and did believe ... that the statements therein were true and that there was no omission to state a material fact required to be stated therein or necessary to make the statements therein not misleading., ${ }^{, 47}$ The rating agencies immediately refused to consent to the use of their ratings in a registration statement, and SEC responded by issuing a no action letter that it would take no action for a period of six months if an asset-backed issuer omitted a ratings disclosure in the registration statement. $^{248}$ Thus, there is no a short term impasse as to whether ratings will be included in a registration, as now required in certain instances, or whether the rating agencies will capitulate and instead insure that their ratings meet the due diligence now required under the 1934 Act.

There were also several changes that might look like merely technical corrections, but which also could be significant. In section $15 \mathrm{E}$ of the 1934 Act, the words "furnished" or "furnishing" were stricken and replaced by the words "filed" or "filing.", 249 The significance of these changes is that there is liability for a false filing under section 18 of the 1934 Act. Arguably, there would not be liability if the material were just "furnished" to the SEC, rather than "filed.",250

\section{b. Structural and Transparency Changes}

In addition to the presently existing power to censure, suspend or revoke the registration of a rating agency, the SEC was also given the power to censure, suspend or bar employees associated with the rating agency, and failure to supervise was added as a basis for discipline. ${ }^{251}$ The SEC was also given additional power to suspend or revoke the registration of the rating agency with respect to a particular class or subclass of securities if the "rating organization does not have adequate financial and managerial resources to consistently produce credit ratings with integrity." 252 The impetus for this

\footnotetext{
${ }^{245}$ H.R. 4173, § 939G.

${ }^{246} 17$ C.F.R. $\$ 230.436$ (g) (2009).

24717 U. S. C. $\S 77 k(b)(3)(B)$.

248 Ford Motor Credit Company No-Action Letter, July 22, 2010, available at http://www.sec.gov/divisions/corpfin/cfnoaction/2010/ford072210-1120.htm.

${ }^{249}$ See, for example, H.R. 4173, § 932(a)(1) (amending 15 U.S.C. §78o-7 (b)).

${ }^{250} 15$ U.S.C. $\S 78(\mathrm{r})$.

${ }^{251}$ H.R. 4173, § 932(a)(3) (amending 15 U.S.C. §78o-7 (d)).

${ }^{252} I d$, (adding sub paragraph (d) (2)).
} 
provision came from the fact that the rating agencies, while doing a professional job with respect to corporate bonds, for example, failed miserably in their ratings of mortgage-backed securities and collateralized debt obligations (CDOs). ${ }^{253}$

A 2008 study by the SEC of credit rating agencies disclosed that, while the number of CDOs grew almost geometrically from 2003 until 2007, the credit rating staff dedicated to reviewing the CDO deals was increased by a miniscule number. See chart below: ${ }^{254}$

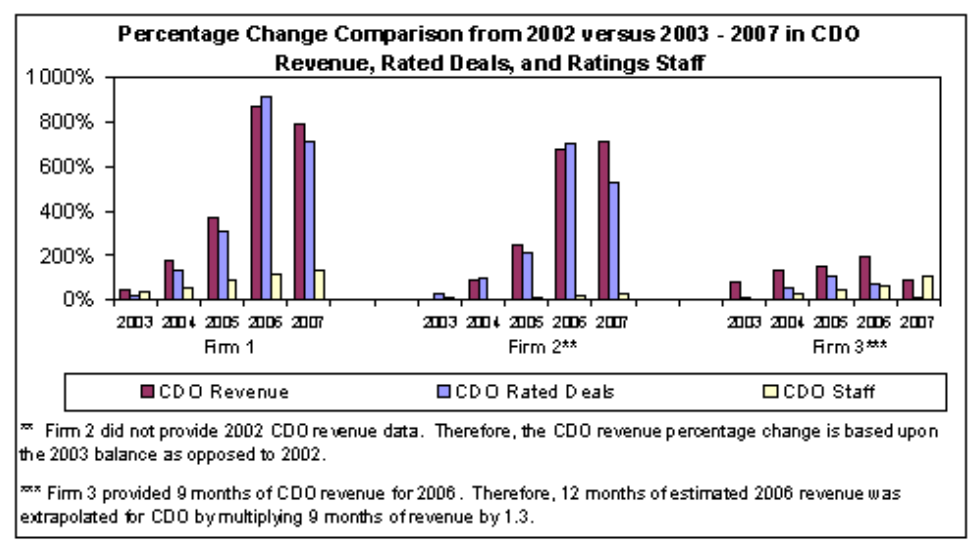

The implicit promise of the new change is that, if the agency does not staff a business segment adequately, the SEC can revoke or suspend its registration with respect to issuing ratings by this segment.

In order to help ensure quality ratings, the Act requires that each rating agency "establish, maintain, enforce, and document an effective internal control structure governing the implementation of and adherence to policies, procedures and methodologies for determining credit ratings." ${ }^{255}$ It further requires that the agency submit annually to the SEC an internal controls report, which would include an assessment of its effectiveness and an attestation by the chief executive officer of such assessment. This is similar to the attestation requirement for chief executive officers of reporting companies under Sarbanes-Oxley. ${ }^{256}$

There is a further requirement in the Act that each rating agency, in effect, have a compliance officer who is essentially independent, that is, he or she does not perform credit ratings, participate in the

\footnotetext{
${ }^{253}$ See supra Part III.B.2. the three major rating agencies), available at http://www.sec.gov/news/studies/2008/craexamination070808.pdf.

${ }^{255}$ H.R. 4173, § 932(a)(2) (adding 15 U.S.C. §78o-7 (c)(3)) .

${ }^{256}$ Pub. L. 107-204 §302, implemented by 17 CFR §240.13a-15.
}

254 SEC, SUMMARY REPORT OF ISSUES IDENTIFIED IN THE COMMISSION STAFF'S

EXAMINATIONS OF SELECT CREDIT RATING AGENCIES, at 11 (2008)(chart comparing revenues, deals, and staff for 
development of methodologies, perform marketing or sales functions, or participate in establishing compensation levels. ${ }^{257}$ Such person, whose compensation cannot be linked to the financial performance of the agency, is required to submit an annual compliance report to the rating agency, which shall file the report with the SEC. The SEC is also required to issue rules "to prevent the sales and marketing considerations" of the rating agency "from influencing the production of ratings" by the rating agency. ${ }^{258}$ Because of the additional responsibilities imposed upon the SEC, the Act instructs the SEC to establish an "Office of Credit Ratings," the director of which should report directly to the Chairman. ${ }^{259}$

In addition to placing these responsibilities upon management, the Act has additional provisions with respect to corporate governance. Each rating agency shall have a board of directors, half of which must be independent and at least one director must be a user of ratings. ${ }^{260}$ The compensation of the independent directors cannot be linked to the business performance of the rating agency. ${ }^{261}$ If the rating agency is a subsidiary of another company, the foregoing responsibilities can be assigned to a committee of the board of directors of the parent company. ${ }^{262}$ The board of directors has the duty to oversee policies and procedures for determining credit ratings, managing conflicts of interest, monitoring the internal control system, and overseeing the compensation and promotion policies and practices. By clarifying responsibilities of the board, this should help to redirect the focus of rating agencies, from merely producing ratings and generating revenue, to a focus on the quality of the ratings.

The Financial Reform Act also added three additional subsections to Section 15E of the 34 Act dealing with transparency of ratings performance, ${ }^{263}$ credit rating methodologies, ${ }^{264}$ and transparency of credit rating methodologies. ${ }^{265}$ Basically, the first provision is designed to require the rating agency to disclose information on its initial ratings for each type of obligor and security, and subsequent changes to the ratings, to enable the evaluation of their accuracy and to provide comparison among rating agencies. The second is to require the SEC to ensure that the procedures and methodologies of the rating agencies are in accordance with policies and procedures which are approved by the board and that material changes are applied consistently; the rating agency is also required to disclose publicly any reason for changes. The third is to require that the rating agencies disclose the assumptions underlying

${ }^{257}$ H.R. 4173, § 932(a)(5) (adding II II (2), H.R. 4173, § 932(a)(8) (striking the existing subsection and adding new 15 U.S.C. $\$ 780-7$ (p). (3), (4), \& (5) to 15 U.S.C. $\$ 780-7$ (j).

${ }^{258}$ H.R. 4173, § 932(a)(4) (adding 15 U.S.C. §78o-7 (h)(3)).

${ }^{259}$ H.R. 4173, § 932(a)(8) (striking the existing subsection and adding new 15 U.S.C. §78o-7 (p)).

${ }^{260}$ H.R. 4173, § 932(a)(8) (adding new 15 U.S.C. §78o-7 (t)).

${ }^{261}$ H.R. 4173, § 932(a)(8) (adding new 15 U.S.C. §78o-7 (t)(2) (C)).

${ }^{262}$ H.R. 4173, § 932(a)(8) (adding new 15 U.S.C. $\left.§ 780-7(t)(4)\right)$.

${ }^{263}$ H.R. 4173, § 932(a)(8) (adding new 15 U.S.C. §78o-7 (q)).

${ }^{264}$ H.R. 4173, § 932(a)(8) (adding new 15 U.S.C. §78o-7 (r)).

${ }^{265}$ H.R. 4173, § 932(a)(8) (adding new 15 U.S.C. §78o-7 (s)). 
their procedures and methodologies and the data that was relied upon, so that users of credit information can understand the ratings process. The SEC was instructed to develop forms for this process to deal with both qualitative issues and quantitative issues. The SEC has already taken some steps in this direction pursuant to the final rules promulgated on February 2, 2009. ${ }^{266}$

These changes have already changed the landscape of credit rating and, hopefully, will return integrity to the credit rating process.

\section{Derivatives: AIG, Goldman Sachs, and Credit Default Swaps}

\section{The Background of the Growth in Derivatives}

No analysis of the financial meltdown would be complete without examining the role of derivatives, particularly credit default swaps ("CDS"), which Warren Buffett has characterized as "instruments of mass destruction."267 One of the difficulties, however, is the lack of information. While Brooksley Born, the former head of the Commodity Futures Trading Commission, foresaw the risks from these instruments and sought to regulate them, ${ }^{268}$ the Clinton administration, led by Rubin and Sommers, ${ }^{269}$ in conjunction with Alan Greenspan, ${ }^{270}$ squelched her efforts and induced Congress, under the leadership of Sen. Phil Gramm, to enact legislation freeing derivatives from regulation. ${ }^{271}$

Following this, the President's Working Group on Financial Markets in 1999 concluded that "the trading of financial derivatives by eligible swap participants should be excluded from the CEA. To do otherwise would perpetuate legal uncertainty or impose unnecessary regulatory burdens and constraints

\footnotetext{
266 See SEC, Amendments to Rules for Nationally Recognized Statistical Rating Organizations, Rel. No. 34-59342, Feb. 2, 2009, available at http://www.sec.gov/rules/final/2009/34-59342.pdf.
}

${ }^{267}$ Quoted in Paul B. Farrell, Derivatives the New 'Ticking Bomb,' WaLL ST. J, Mar. 10, 2008, available at http://www.marketwatch.com/news/story/derivatives-new-ticking-time-bomb/story.aspx?guid=\%7BB9E54A5D-4796-4D0DAC9E-D9124B59D436\%7D\&print=true\&dist=printTop.. The use of derivatives is alleged to have contributed to the current economic crisis in Europe since Greece used derivatives developed by Goldman Sachs and other investment bankers to hide its shaky financial position. See Louise Story, Landon Thomas Jr., and Nelson D. Schwartz, Wall Street Helped to Mask Debts Shaking Europe, NEW YORK TIMES, Feb. 14,2010.

\footnotetext{
${ }^{268}$ See Proposed Rules, Commodity Futures Trading Commission, May 12, 1998, 63 Fed. Reg. 26, 114, available at http://web2.westlaw.com/Find/default.wl?bhcp $=1 \&$ cite $=63+\mathrm{fr}+26114 \& \mathrm{rs}=\mathrm{LAWS} 2 \% 2 \mathrm{E} 0 \&$ strRecreate $=$ no\&sv $=\mathrm{Split} \& \mathrm{vr}=1 \%$ $\underline{2 \mathrm{E} 0 .}$.

${ }^{269}$ See Brooskley Born \& the Regulatory Limit of Democrats, (Nov. 11, 2008), available at http://cobb.typepad.com/cobb/2008/11/brooksley-born.html; Peter S. Goodman, Taking Hard New Look at a Greenspan Legacy, N.Y. TIMES, Oct. 8, 2008, available at http://www.nytimes.com/2008/10/09/business/economy/09greenspan.html.

${ }^{270}$ See Goodman, supra note 269.

${ }^{271}$ See Commentary, The Commodity Futures Modernization Act of 2000, available at http://www.uspoliticsonline.com/economic-issues/47424-commodity-futures-modernization-act-2000-a.html; see also Blind Faith: How Deregulation and Enron's Influence Over Government Looted Billions from Americans, available at http://www.citizen.org/cmep/energy_enviro_nuclear/electricity/Enron/articles.cfm?ID=7104.
} 
upon the development of these markets in the United States."272 At that time, the volume of OTC derivative contracts was $\$ 80$ trillion. The volume has now grown to $\$ 600$ trillion. ${ }^{273}$ The markets have certainly developed! Compare this to our gross domestic product in 2008 of about $\$ 14.2$ trillion. $^{274}$ Derivative contracts, however, are reported in notional value. In other words, if you had a $\$ 1$ million dollar loan, the notional value of a derivative credit default swap contract is reported as $\$ 1$ million, even though the risk of loss may not be anywhere near that figure. ${ }^{275}$ But the fact that credit default swaps are privately traded make transparency, and accurate information, difficult. ${ }^{276}$

According to the Comptroller of the Currency, in the third quarter of 2009, US commercial banks held \$204.3 trillion of derivative contracts, and the current credit exposure was $\$ 484$ billion. $^{277}$ This report, however, covered only a fraction of the overall derivatives market and gives gross information without significant detail. In previous reports, the Comptroller of the Currency noted that "[f]rom 2003 to 2007 creditor derivative contracts (CDSs) grew at a 100\% compounded annual growth rate, ${ }^{, 278}$ from about $\$ 1$ trillion in 2003 to about $\$ 16$ trillion in $2007 .{ }^{279}$ This is illustrated below: ${ }^{280}$

\footnotetext{
${ }^{272}$ Over-the-Counter Derivatives Markets and the Commodity Exchange Act: Report of The President's Working Group on Financial Markets at 1, available at http://www.treas.gov/press/releases/reports/otcact.pdf

${ }^{273}$ Bank of International Settlements, SEMIANNUAL OTC DERIVATIVES STATISTICS AT END-DECEMBER 2009, Table 19, available at http://www.bis.org/statistics/otcder/dt1920a.pdf.

${ }^{274}$ See Google "Gross Domestic Product," available at http://www.google.com/publicdata?ds=wb$\underline{\text { wdi\&met=ny_gdp_mktp_cd\&idim=country:USA\&dl=en\&hl=en\&q=gross+domestic }+ \text { product }}$

275 See OFFICE OF THE COMPTROLLER OF CURRENCY, QUARTERLY REPORT ON BANK TRADING AND DERIVATIVES ACTIVITIES THIRD QUARTER 20086 (2008) [hereinafter OCC 2008 Report].

${ }^{276} I d$.

277 OFFICE OF THE COMPTROLLER OF CURRENCY, QUARTERLY REPORT ON BANK TRADING AND DERIVATIVES ACTIVITIES THIRD QUARTER 20091 (2009).

${ }^{278}$ OCC 2008 Report, supra note 275, at 5.

${ }^{279} I d$. at 10 , fig. 2 .

${ }^{280} I d$.
} 
Derivative Contracts by Type (\$ Billions)*

\begin{tabular}{|c|c|c|c|c|c|c|c|c|c|c|c|c|c|c|}
\hline Sin Blore & 9804 & 9904 & 0006 & CIQ4 & $\infty 006$ & 0304 & $0+24$ & OSOS & CSO4 & $\infty x_{4}$ & 0804 & $\csc 1$ & $\cos 2$ & 0503 \\
\hline Interest Rate & 24,765 & 27772 & 32,958 & 38,306 & 48,347 & 61,955 & $75,5: 8$ & 90,520 & $107,4: 5$ & 129,574 & 164404 & 169,373 & 171,903 & 172,561 \\
\hline Foreipn Exch & 7,345 & 5,915 & 6,039 & 5,736 & 6,075 & $7, \pm 82$ & 8,607 & 9280 & 14,900 & 16,514 & 16,8094 & 8,872 & 15,156 & 15,609 \\
\hline Equities & 501 & $6 / 2$ & 850 & 700 & 785 & 229 & 1,120 & 1,265 & 2277 & 2,522 & 2200 & 2,174 & 2,012 & 2,182 \\
\hline Commedities & $5 a 3$ & 171 & 22 & 179 & 233 & $2: 4$ & 299 & $\$ 96$ & 933 & 1,003 & 1.050 & 938 & 969 & 926 \\
\hline Credit Deituatives & sh & 287 & 46 & 355 & 635 & $1, \infty x 1$ & 2,377 & $5,8,2$ & 9,019 & 15,851 & 15,895 & 4,307 & 13,440 & 12,986 \\
\hline TTAL & 32,999 & अ,916 & $9,5,3$ & 45,38 & 56,075 & 71,062 & 87,350 & 101,477 & 131,499 & 158,545 & 200,30 & 201,301 & 208,450 & 204.264 \\
\hline
\end{tabular}

"In billions of dolars, notional amount of totat futures, exchange traded options, over the counter options, forwards, and swaps.

As of Q206 equities and commosibes tppes are shown as separate categories. They were previously shown as "Other Deriva."

\section{AIG's Entry into the Derivative Business and Its Downfall}

The federal government's bailout of AIG, which could have been as much as $\$ 182.5$ billion, ${ }^{281}$ has prompted Congress to seek detail from AIG about its derivative activity. ${ }^{282}$ Unfortunately, the SEC initially supported AIG in keeping secret the details of AIG's funneling of millions of dollars of bailout money to major financial institutions ${ }^{283}$ to satisfy, arguably at 100 cents on the dollar, AIG's obligations under credit default swaps it issued to the institutions. ${ }^{284}$ The exhibit detailing this information was recently disclosed to the public, ${ }^{285}$ listing more than a dozen financial institutions, domestic and foreign, that were the beneficiary of the credit default swaps issued from AIG. ${ }^{286}$ It also listed the various tranches of mortgage-backed securities that were insured ${ }^{287}$ and the notional value of the credit default swaps, or CDSs, which were over $\$ 62$ trillion and which reflected an obligation of AIG under the CDSs of over $\$ 32.5$ billion. $^{288}$

${ }^{281}$ See joint press release, U.S. Treasury and Federal Reserve Board Announce Participation in AIG Restructuring Plan, Mar. 2, 2009, available at $h \mathrm{ttp}: / / \mathrm{www}$. federalreserve.gov/newsevents/press/other/20090302a.htm

${ }^{282}$ See Jim Puzzanghera, Geithner Defends AIG Bailout at House Hearing, L.A. TIMES,JAN. 28, 2010, available at http://articles.latimes.com/2010/jan/28/business/la-fi-aig-geithner28-2010jan28

${ }^{283}$ Matthew Goldstein, SEC Order Helps Maintain AIG Bailout Mystery, REUTERS (New York), Jan. 11, 2010,
http://www.reuters.com/assets/print?aid=USN1116982020100111.

${ }^{284}$ See Reuters DealZone, AIG's Mysterious Schedule A Finally Revealed, http://blogs.reuters.com/reutersdealzone/2010/01/27/aigs-mysterious-schedule-a-finally-revealed/ (Jan. 27, 2010, 15:02 EST) (characterizing the AIG bailout as a "gift to the Wall Street banks").

${ }^{285} I d$.

${ }^{286}$ AIG, Schedule A - List of Derivative Transactions, available at http://static.reuters.com/resources/media/editorial/20100127/Schedule\%20A.pdf

${ }^{287} I d$. at 5 .

${ }^{288}$ Id. 
What were the incentives that led AIG, which had prided itself on its AAA credit rating, and its ability to manage and hedge risk, to incur liabilities of this magnitude?

By way of background, the "quants",289 behind AIG's entry into the derivative business were Howard Sosin and Randy Rackson. When they left Drexel to form the Financial Products unit at AIG, they negotiated for $38 \%$ of the profits, ${ }^{290}$ a nice incentive, and set up a system that supposedly "married technology, intelligence, verve, and cultural discipline." 291 According to them, "[t]he excitement of it wasn't the money. The money was the scorecard. The drive behind it was creating something new."292 The first derivative they entered into was a $\$ 1$ billion interest rate swap that was ten times larger than the typical Wall Street swap at that time. A swap of this sort had minimal exposure vis-a-vis its notional value and could be hedged. It earned Financial Products $\$ 3$ million, as much as AIG's other financial operations earned in a year. ${ }^{293}$ This encouraged additional focus upon derivatives.

Ten years later, Financial Products created a new derivative contract, a credit default swap, or CDS. This instrument looked like it could mint money; the computer model showed that AIG would have a $99.85 \%$ chance of never having to make any payment. ${ }^{294}$ Tom Savage, the president of Financial Products at that time, stated that "[t]he models suggested that the risk was so remote that the fees were almost free money. Just put it on your books and enjoy the money." ${ }^{295}$ However, the computer models were based upon corporate debt, a subject upon which there existed years of historical financial data.

Unfortunately, AIG moved into guaranteeing securities involving mortgage-backed securities, or MBSs, including collateralized debt obligations, or CDOs, which increasingly incorporated subprime and alt A loans. Not only were there limited historical data on these loans, but the data that did exist were stale since, as discussed earlier, underwriting standards were eroding. ${ }^{296}$ Paul Wilmot, one of the world's leading quants, stated with respect to CDOs: "They built these things on false assumptions without testing them, and stuffed them full of trillions of dollars. How could anyone have thought that

\footnotetext{
289 "Quants" is the designation in financial circles of highly educated and sophisticated people who do quantitative analysis, basically the application of higher mathematics to finance. Sosin was a finance scholar who had honed his theories at Bell Labs before moving to Drexel Burnham Lambert, while Rackson was a computer wizard from the Wharton business school. See Robert O'Harrow Jr. \& Brady Dennis, What Went Wrong: The Beautiful Machine, WASH. POST, Dec. 29, 2008, http://www.washingtonpost.com/wpdyn/content/article/2008/12/28/AR2008122801916_pf.html

${ }^{290}$ O’Harrow, Jr. \& Dennis, supra note 289, at subdiv. 3.

${ }^{291} I d$

${ }^{292} I d$.

${ }^{293}$ Id., at subdiv. 4.

${ }^{294}$ Brady Dennis \& Robert O'Harrow Jr., A Crack in the System, WASH. PosT, Dec. 30, 2008, http://www.washingtonpost.com/wp.dyn/content/article/2008/12/29/AR2008122902670_pf.html.

${ }^{295} I d$.

${ }^{296}$ See supra Part II, text at notes 8-16.
} 
was a good idea? ... We don't have the tools yet to truly price them. People thought we did, but they were nowhere near robust enough." 297 In other words, garbage in equals garbage out.

It was the reliance upon its AAA rating that, in part, led to AIG's downfall. To appreciate this, consider the interrelationships between the CDOs issued by the investment bankers and the credit default swaps issued by AIG. As stated earlier, a CDO is a complex instrument. First, take a pool of mortgages whose tranches are rated from AAA to BB or even unrated. Then take slices, some BBB, some BB and lower, and put them in a CDO. Even though none of the mortgage slices are AAA, the rating agencies would give the top tranches of the $\mathrm{CDO}$ an AAA rating, arguably because it had the first claim on payments in the CDO pool and was undergirded by the lower tranches. ${ }^{298}$ This is somewhat similar to the medieval alchemists who supposedly made gold out of base metal. To enhance the top tranche, the investment bankers would purchase credit default insurance from AIG or another vendor.

The AAA tranche now looks good to investors. In fact, so good that there was less interest in the lower rated tranches, with the result that the financial institutions who syndicated the lower rated CDOs sometimes got stuck with them, a subject discussed in the next section. But the AAA tranche was readily salable: its income was undergirded by the lower tranches and was guaranteed by AIG, with its AAA credit rating; consequently it was rated AAA by the rating agencies.

The undergirding by the lower rated tranches was somewhat illusory. If there were ten tranches, the image might be of a cylinder, with the top tranche undergirded by the nine lower tranches. Thus the top tranche would not be affected until ninety percent of value had been lost. But, in reality, the picture was similar to a cone. In one $\$ 1,793,610,000$ offering of mortgage backed securities, five tranches totaling $\$ 1,483,410,000$ were rated AAA, and another seven tranches totaling $\$ 251,650,000$ were rated A- or better. The last three tranches, rated BBB+ to BBB-, totaled only $\$ 58,550,000$. So, while there

\footnotetext{
${ }^{297}$ Matthew Phillips, Revenge of the Nerd, NEWSWEEK, June 8, 2009, at 51, available at http://www.newsweek.com/id/200015/output/print.

${ }^{298}$ The tranching process itself is deceptive. The SEC explained the process as follows:
}

For example, if a trust issued securities in 10 different tranches of securities, the first (or senior) tranche would have nine subordinate tranches, the next highest tranche would have eight subordinate tranches and so on down the capital structure. Losses of interest and principal experienced by the trust from delinquencies and defaults among loans in the pool are allocated first to the lowest tranche until its principal amount is exhausted and then to the next lowest tranche and so on up the capital structure. Consequently, the senior tranche would not incur any loss until the principal amounts from all the lower tranches have been exhausted through the absorption of losses from the underlying loans.

See Proposed Rules for Nationally Recognized Statistical Rating Organization, Exchange Act Release No. $34-57967$ [File No. S7-13-08] at 11 (June 16, 2008), at 9-10. This suggests a linear relationship, in other words, the top tranche is supported by the assets and income expected by the other nine tranches. But, for example, in the Ameriquest Mortgage Securities, Inc/Asset Backed Pass-Through Certificates/Series 2005-R11 . 424B5, Dec. 19, 2005, SEC File 333-121781-11, in a $\$ 1,793,610,000$ offering of mortgage backed securities, five tranches totaling $\$ 1,483,410,000$ were rated AAA, and another seven tranches totaling $\$ 251,650,000$ were rated $\mathrm{A}$ - or better. The last three tranches, rated $\mathrm{BBB}+$ to $\mathrm{BBB}-$, totaled only $\$ 58,550,000$. So, while there were twelve tranches below the AAA tranches, they totaled only $17 \%$ of the offering. SEC Info - Ameriquest Mortgage Securities Inc/Asset Backed Pass-Through Certificates/Series 2005-R11, http://www.secinfo.com/dr66r.z2F9.htm, at 1, 88 (last visited Feb. 16, 2010). 
were twelve tranches below the AAA tranches, they totaled only $17 \%$ of the offering. ${ }^{299}$ This is illustrated below:

\section{This is a more accurate picture of the tranches}

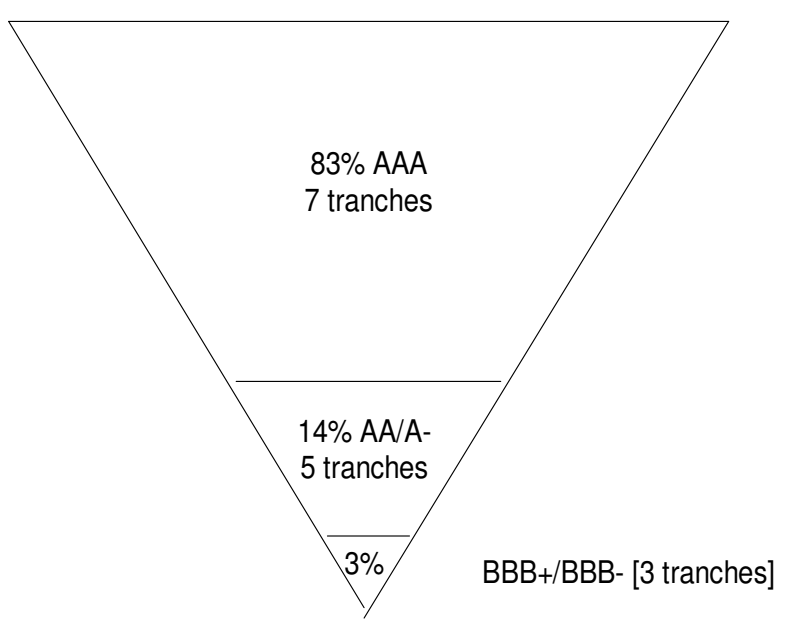

The problem was that, by 2007, "[d]eals were flying out so fast that the Wall Street firms sometimes could not tell investors what specific collateral was going into which CDO, making a mockery of anyone who tried to do a fundamental analysis of the assets backing the bonds before agreeing to buy." 300 For example, in February and March of 2007, Merrill Lynch sold \$29 billion of securities, $60 \%$ more than any other two-month period, leading to the profits and stock price growth previously discussed. But, even under the pressure of this volume, the rating agencies were churning out their triple-A ratings for securities that, in a few months, the rating agencies would be downgrading. ${ }^{301}$

${ }^{299}$ SEC Info - Ameriquest Mortgage Securities Inc/Asset Backed Pass-Through Certificates/Series 2005-R11, Dec. 19, 2005, SEC File 333-121781-11, available at http://www.secinfo.com/dr66r.z2F9.htm, at 1, 88 (last visited Feb. 16, 2010).

${ }^{300}$ Jill Drew, Frenzy, WASH. PosT, Dec. 16, 2008, http://www.washingtonpost.com/wpdyn/content/article/2008/12/15/AR2008121503561_pf.html. To hide its exposure to its subprime mortgages, Merrill Lynch created special-purpose entities into which it dumped subprime mortgages. The entities were funded through the issuance of short-term notes to investors which, supposedly, enabled Merrill Lynch to sell the mortgages and receive cash. But the notes were guaranteed by Merrill Lynch so Merrill Lynch is liability was essentially unchanged. See Louise Story, Merrill's Risk Disclosure Dodges Are Unearthed, N.Y. TimeS, AUg. 10, 2010, available at http://www.nytimes.com/2010/08/10/business/10merrill.html?dbk

${ }^{301}$ See supra Part III.B.2.. 
Then came the chain reaction. Apparently, AIG did not need to post collateral as long as it maintained its own AAA rating. But, when it was downgraded to AA, it was required to post collateral as the CDOs began to default. As the CDOs were downgraded, more collateral calls came, triggering a liquidity crisis. ${ }^{302}$ To complete the picture, as the CDOs dropped in value, the capital of the financial institutions became impaired. $^{303}$

\section{Credit Default Swaps, Goldman Sachs and Magnetar}

There are several issues with the derivatives known as credit default swaps. One is the problem of transparency, that is, the lack of information not only about volume but also the resources, or lack thereof, backing the guarantee. The CDOs are essentially incomprehensible. ${ }^{304}$ But neither the underwriter nor the buyer nor the rating agency needed to worry when a AAA business like AIG was guaranteeing the obligation. Assuming, of course, AIG had the financial wherewithal to support its guarantee. The problem is similar to that of the mortgage bankers: they did not need to worry about the credit worthiness of the mortgagor if they could sell the mortgages to an investment banker who would securitize them. With respect to the resulting CDOs, neither the underwriter nor the buyer needed to worry as long as the rating agency gave the instrument a AAA rating and a AAA company like AIG guaranteed the obligation. With no likely liability, no need to do due diligence! Everybody was making so much money, or so they thought, that nobody needed to worry.

The second issue is that the credit default swap is unlike an interest rate swap or currency swap in which a party is trying to hedge its risk from activities, such as the change in interest rates or a change in currency value, over which it has no control. But in a credit default swap, the creditor who is seeking protection from another is the very person who has the greatest opportunity to assess the risk because the creditor is directly involved in creating the debt instrument. Thus, there is a marked asymmetry in information between the creditor who seeks protection, and who has or should have done the due diligence and have the relevant information, and the issuer of the swap who provides protection.

In effect, the creditor is buying insurance against the debtor's default. But since this is not treated as insurance, up to now there has been no obligation that the guarantor of the debt would need to set asides reserves adequate to fund the expected losses. Unfortunately, companies like AIG assumed that there would be no losses and that the "premiums" were pure profit.

Accordingly, from a policy perspective, should credit default swaps even exist? Just because an "innovative" financial instrument can be created, such as pic-a-pay mortgage loans, does not necessarily mean that it should be created. While there are those who consider all derivatives gambling, there is no question that interest rate swaps and currency swaps fulfill a useful business function through hedging risks that neither party controls. But to carry forward the gambling analogy, CDSs are gambling with loaded dice since the insured has better data than the insurer.

\footnotetext{
${ }^{302}$ Robert O’Harrow Jr. \& Brady Dennis, Downgrades and Downfall, WASH. Post, Dec. 31, 2008, http://www.washingtonpost.com/wp-dyn/content/article/2008/12/30/AR2008123003431_pf.html.

${ }^{303}$ See supra III.B.3.c.

${ }^{304}$ See supra text at notes 298-300.
} 
Just like insuring your home, should not a purchaser of credit protection have an insurable interest? An unrelated third party could not purchase insurance on your home because of moral hazard: there is no downside to the third party if your home burns [but there certainly is to you], but there is a substantial upside from the insurance payout if your home burns. This is the moral hazard issue. But, in the financial world, an unrelated third-party can purchase credit default swap insurance. Moreover, if we do not require an insurable interest, there is no limit to the amount of the insurance that can be purchased. This is destabilizing because the effect of one obligor failing is magnified by the number of credit default swaps outstanding on that obligor.

Sen. Dorgan had proposed banning "naked credit default swaps," but the proposal ran into stiff resistance. $^{305}$ The argument was made that persons other than a creditor could have a stake in the financial strength of a debtor, such as a supplier to or landlord of a business. This has some superficial plausibility; however, is the market for CDSs composed of suppliers or landlords, or rather speculators? A better argument is that a CDS market does provide pricing information and liquidity. But, at what price?

The moral hazard involved in credit default swaps burst into the headlines when the SEC sued Goldman Sachs and an employee, Fabrice Tourre, in connection with a synthetic CDO, Abacus 2007$\mathrm{AC} 1$, that Goldman structured and marketed to investors. ${ }^{306}$ While a CDO is based on the performance of the underlying mortgage-backed securities, a synthetic CDO involves credit default swaps on the underlying mortgage-backed securities. The person buying protection pays a premium to the provider of protection. Thus, the purchasers of the synthetic CDO would receive their income from the premiums; on the other hand, the person receiving protection would only benefit if the underlying securities defaulted. Thus, the buyer of protection wants the house to burn down.

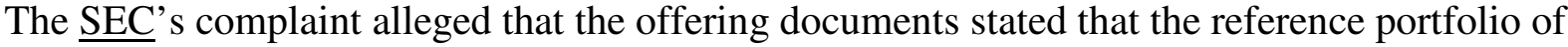
residential mortgage-backed securities was chosen by ACA Management, a company experienced in analyzing credit risk in this area. In point of fact, Paulson \& Co. had approached Goldman about creating a synthetic CDO since Paulson wanted to bet against the subprime market. Paulson participated in the choice of the mortgage-backed securities against which the investors would provide protection, and then purchased such protection. Consequently, it was in his interest to choose securities likely to default, or experience what are known as credit events.

Goldman's "sin" was in failing to disclose the role of Paulson. Consequently, the question was whether Paulson's role was a material fact, the omission of which would give rise to liability. While the reaction of many would be that any investor would want to know that the impetus for creating the investment in question came from someone who wanted the investment to fail, a countervailing argument is that, in any credit default swap, there must be a counter party who is betting against the swap. Investors cannot get the benefit of selling protection unless there is someone who wants to buy the

\footnotetext{
${ }^{305}$ See, for example, David M. Mason, The Senator Has No Clothes: Why a Ban on'Naked' Credit Default Swaps Is IllAdvised and Impractical, The Heritage Foundation, May 5, 2010, available at http://www.heritage.org/Research/Reports/2010/05/The-Senator-Has-No-Clothes-Why-a-Ban-on-Naked-Credit-DefaultSwaps-Is-Ill-Advised-and-Impractical.

${ }^{306}$ SEC v. Goldman Sachs \& Co. and Fabrice Tourre, 10 Civ. 3229, U.S.D.Ct., S.D.N.Y., filed Apr. 16, 2010, available at http://www.sec.gov/litigation/complaints/2010/comp21489.pdf.
} 
protection. However, if the buyer had an insurable interest, such that the buyer had a stake if the investment went bad, there would not be the same degree of moral hazard as when the buyer has no stake in the underlying assets, but only believes that they will fail, and wants to make money on that gamble.

Just prior to the filing of the SEC complaint against Goldman, ProPublica released a report detailing how one hedge fund created CDOs in 2006-2007 that helped keep the subprime market going. ${ }^{307}$ At this time, there were ominous signs about the housing market, and securitization was becoming more difficult since fewer investors were available to purchase the lower or equity tranches of CDOs. Magnetar filled this void, but then bet against the higher rated tranches by purchasing credit default swaps. Since the equity tranche has the highest interest rate, as long as the housing market continued, Magnetar had interest income to cover on its premium payments on the CDSs. But when the market crashed, Magnetar was rewarded even more handsomely by its recovery on the swaps. It profited as the market went up and it profited many times over when the market fell.

On July 15, the SEC announced that Goldman had settled, had agreed to pay a $\$ 550$ million penalty ( $\$ 250$ million to be returned to investors and $\$ 300$ million to be paid to the U.S. Treasury), and had acknowledged that it had misstated or omitted key facts:

Goldman acknowledges that the marketing materials for the ABACUS 2007-AC1 transaction contained incomplete information. In particular, it was a mistake for the Goldman marketing materials to state that the reference portfolio was "selected by" ACA Management LLC without disclosing the role of Paulson \& Co. Inc. in the portfolio selection process and that Paulson's economic interests were adverse to CDO investors. Goldman regrets that the marketing materials did not contain that disclosure. ${ }^{308}$

Goldman also agreed to remedial action in connection with its review and approval of mortgagebacked securities, including the use of outside counsel in the review of marketing materials for such offerings and the training of its employees in connection with its business standards.

\section{The Response of the Financial Reform Act To Derivatives}

As the current crisis developed, regulators began considering a central clearinghouse to provide some degree of transparency. As the Comptroller of Currency stated in its 2008 report, "[ $t$ ]he OCC is working with other financial supervisors and major market participants to address infrastructure issues and credit derivatives, including a central counterparty clearinghouse strategy." "309 Even the 1999 President's committee report recognized:

\footnotetext{
307 Jesse Eisinger and Jake Bernstein, The Magnetar Trade: How One Hedge Fund Helped Keep the Bubble Going, ProPublica, April 9, 2010, available at http://www.propublica.org/article/the-magnetar-trade-how-one-hedge-fund-helpedkeep-the-housing-bubble-going

308 SEC press release, Goldman Sachs to Pay Record $\$ 550$ Million to Settle SEC Charges Related to Subprime Mortgage CDO, July 15, 2010, available at http://www.sec.gov/news/press/2010/2010-123.htm.

${ }^{309}$ OCC 2008 Report, supra note 275, at 6.
} 
[C]learing systems can serve a valuable function in reducing systemic risk by preventing the failure of a single market participant from having a disproportionate effect on the overall market. Clearing systems also facilitate the offset and netting of obligations arising under contracts that are cleared through the system. Because they may serve to concentrate diffuse credit risks in a single entity, however, clearing systems should be subject to regulatory oversight in order to help ensure that proper risk management procedures are established and implemented and that the clearing system is properly structured.

Some support had also developed from industry to regulate derivatives and create a clearing authority. An industry survey reported that "[t]he case is most pressing for credit default swaps" stated above, are instruments replete with moral hazard.

As finally enacted, Title VII of the Financial Reform Act deals extensively with derivatives. ${ }^{311}$ At the outset of Title VII, the Act explicitly provides that "no federal assistance may be provided to any swaps entity with respect to any swap, security-based swap, or other activity of the swaps entity."312 A swaps entity is any "swap dealer, security-based swap dealer, major swap participant, or major securitybased swap participant." ${ }^{113}$ This could impact depository institutions. However, a depository institution can establish a subsidiary that is a swaps entity ${ }^{314}$ it is also permitted to engage in hedging and risk mitigating activities relating to its business, but not credit default swaps unless they are cleared. ${ }^{315}$ It also gives the CFTC and the SEC authority to issue a report with respect to any type of swap that is determined to be detrimental to the stability of a financial market or to participants in a financial

${ }^{310}$ See, Centraized Clearing for OTC Derivatives Receives Industry Support but Concerns Remain, FINEXTRA, Feb. 4, 2010, available at http://www.finextra.com/news/fullstory.aspx?newsitemid=21043.

${ }^{311}$ H.R. 4173, §§ 701-774. Title VII was summarized by the Conference Committee as follows:

- Mandatory clearing of swaps and security-based swaps for those trades that are eligible for clearing as determined by both the clearing houses and the regulators;

- Mandatory trading on an exchange or swap (or security based swap) execution facility should the transactions be cleared and a facility will accept it for trading;

- Public trade reporting of all cleared and uncleared swaps and security-based swaps;

- Regulators have authority to impose capital on dealers and major swap participants;

- Regulators have authority to impose margin requirements only on dealers and major participants for uncleared swaps, adding safeguards to the system by ensuring dealers and major swap participants have adequate financial resources to meet obligations;

- Position limits on swaps contracts that perform or affect a significant price discovery function and requirements to aggregate limits across markets; and

- Prohibitions against market manipulation.

See JOINT EXPLANATORY STATEMENT OF THE COMMITTEE OF CONFERENCE TO ACCOMPANY H.R. 4173, available at http://docs.house.gov/rules/finserv/111_hr4173_finsrvcrjes.pdf.

${ }^{312}$ H.R. 4173, § 716 (a).

${ }^{313}$ H.R. 4173, § 716 (b) (2).

${ }^{314}$ H.R. 4173, § 716 (c).

${ }^{315}$ H.R. 4173, $\$ 716$ (d). 
market. ${ }^{316}$ Hopefully, the federal regulators will review the desirability of naked credit default swaps. The Act precludes the regulation of swaps as insurance under state law. ${ }^{317}$

The goal of the act was basically to improve transparency through public reporting of transaction and pricing data, ${ }^{318}$ and to create clearing and margin requirements, which would reduce counter-party and systemic risk. This would be accomplished by having as many derivatives as possible centrally cleared $^{319}$ and traded on exchanges, and by subjecting swap dealers and major market participants ${ }^{320}$ to capital requirements and margin requirements, both the initial and variation. ${ }^{321}$ The Act requires registration of derivatives clearing organizations, ${ }^{322}$ swap data depositories, ${ }^{323}$ swaps dealers and major swap participants, ${ }^{324}$ and swap execution facilities. ${ }^{325}$

These provisions will not take effect for 360 days ${ }^{326}$ and require extensive rulemaking, particularly by the CFTC and the SEC. The scope of this undertaking is massive. It remains to be seen to what extent derivatives can be standardized, so as to be exchange-traded and cleared. The determination of

\footnotetext{
${ }^{316}$ H.R. 4173, § 714.

${ }^{317}$ H.R. 4173, § 722(b).

${ }^{318}$ H.R. 4173, $\$ 727$ (adding 7 U.S.C. $\$ 2$ (a) (13)1 (4)(providing for real-time public reporting of cleared swap transactions; with respect to swaps that are not cleared, real-time public reporting is required but in a manner that does not disclose the business transactions and market positions of any person).
}

${ }^{319}$ H.R. $4173 \S 723$ (adding 7 U.S.C. $\$ 2$ (h)(clearing is mandatory but the CFTC can determine if a particular swap or category of swap should be cleared; there is also an exception for clearing if one of the counterparties is not a financial entity, is using the swap to hedge commercial risk, and notifies the CFTC as to how it will meet its financial obligations with respect to swaps).

${ }^{320}$ A major market participants is any person who is not a swap dealer and who maintains a substantial position, not held for hedging, and whose outstanding swaps create substantial counterparty exposure, or is a financial entity that is highly leveraged, and not subject to federal banking capital requirements, and who maintains a substantial position in swaps. See H.R. 4173, §721(a) (16)(adding 7 U.S.C. § 1a(33)).

321 H.R. 4173, $§ 731$ (adding 7 U.S.C. $\$ 4$ s (e)(the federal regulators are instructed to adopt rules imposing capital requirements, and initial and variation margin requirements for swaps that are not cleared, for swap dealers and nature swap participants.) For swaps that are cleared, the swaps clearing organization must have core principles that include risk management, which encompasses margin from each member and participant that is "sufficient to cover potential exposures to normal market conditions." H.R. $4173 \S 725$ (adding 7 U.S.C. $§ 7 a-1$ (c)(2)(D)).

${ }^{322}$ H.R. 4173, $\$ 725$.

${ }^{323}$ H.R. 4173, $§ 728$ A swap data repository is a person that collects and maintains information or records with respect to transactions or positions in, or the terms and conditions of, swaps entered into by others. See H.R. 4173 §721(a)(21) (adding 7 U.S.C. $\S 1 \mathrm{a}(48))$.

${ }^{324}$ H.R. 4173, § 731.

${ }^{325}$ H.R. 4173, § 733.

${ }^{326}$ H.R. 4173, $§ 774$ (or 60 days after publication of a final rule or regulation implementing a provision of Title VII).. 
capital and margin requirements is left to rule-making. But, from a standpoint of transparency, the Act is a major step in the right direction.

\section{Conclusion}

Paradoxically, during this past decade, a dramatic an increase in wealth has led to a drastic decrease in wealth, as the demand created by the surge in assets under investment sparked the creation and bundling of toxic mortgages, that in turn led to the financial crisis.

Numerous factors coalesced to lead to the meltdown. Borrowers, mortgage brokers, and mortgage lenders combined to create unsound mortgages that were candidates for default. Liars' loans and "affordable" 2/28 mortgages with teaser rates were "manufactured," primarily by non-bank lenders, and sold to GSEs and investment banks to package into securities. Thus, the lender and the investment banker sloughed off their economic risk and neither had "any skin in the game," which led to an absence of sound underwriting and due diligence.

Had the Financial Reform Act been in effect in 2000, this probably would not have occurred. Financial institutions now must make a good faith determination, based on verified documentation, that the borrower can repay the loan on a fully amortized basis, and not based on an initial teaser rate. If the lender or investment bank is not dealing with a "qualified loan," the institution must retain a portion of the risk. Predatory lending should also be mitigated by the oversight of the new Consumer Financial Protection Bureau.

From the standpoint of the lender, the investment banker, and the credit rating agency, more business means more profits, which leads to higher stock prices and greater executive compensation. Thus management has an incentive to take undue risk. The entire subject of stock options needs to be reexamined, and clawback clauses need to become standard in management contracts to stem short-term opportunism. The Financial Reform Act takes a step in this direction, but only a small one.

Leverage, or phrased differently, inadequate capitalization, is the stuff out of which great fortunes are made. Unfortunately, as the past few years have witnessed, it is also the stuff out of which great bankruptcies are made. The problem of excessive leverage has been recognized in the Financial Reform Act, but the solution has been left to the regulators. To a certain extent, the Volcker rule, as embodied in the Act, will cause some separation of trading and banking activities. But little has been done to stem the concentration of financial power. This has been aggravated by the financial crisis, as failed institutions such as Countrywide and Merrill Lynch have been acquired by Bank of America, and Bear Stearns and Washington Mutual by J.P. Morgan Chase.

The credit rating agencies were probably the most reprehensible players, since they held themselves out as guardians of integrity while selling their AAA ratings to make a fast buck. The investment community relied upon the rating agencies to its detriment. Thousands of ratings were dramatically downgraded, sometimes only months after they were issued. The short-term perspective cost the rating agencies a high price since, under the Financial Reform Act, they are now highly regulated, compelled to be transparent, and have lost their supposedly First Amendment protection against civil liability. However, there still remains the problem that the entity that seeks the rating pays the rating agency. 
Whether the problems relating to derivatives have been resolved is still an open question. There is a serious moral hazard when the financial institution that creates a debt or securitized instrument purchases credit insurance from another entity, such as AIG. Because of the informational asymmetry, this enables the creator of the instrument to insure against its own lack of due diligence. Moreover, when people trade credit default swaps without having an interest in the underlying obligation, the effect of default is magnified throughout the system.

The derivative business certainly will be more transparent, which is a powerful step in the right direction. But the extent to which derivatives will be cleared and traded on exchanges, with capital and margin requirements to protect counterparties and the economic system, remains to be seen.

Overall, the Financial Reform Act is a substantial step in the right direction, but additional steps still need to be taken. The overall key to avoiding financial crises is integrity and courage. The corporate culture needs to reject the ethnic reflected in "let's hope we are all wealthy and retired by the time this house of cards falters." And politicians need the courage to stand up to lobbying pressure and do what is necessary to curb the concentration of power in our financial system and management incentives for short-term profits. 